San Jose State University

SJSU ScholarWorks

Master's Theses

Master's Theses and Graduate Research

1990

\title{
A hydrogeological investigation of ground water recharge near the drainage retention basin, Lawrence Livermore National Laboratory, Livermore, California
}

Kenneth Charles Toney

San Jose State University

Follow this and additional works at: https://scholarworks.sjsu.edu/etd_theses

\section{Recommended Citation}

Toney, Kenneth Charles, "A hydrogeological investigation of ground water recharge near the drainage retention basin, Lawrence Livermore National Laboratory, Livermore, California" (1990). Master's Theses. 79.

DOI: https://doi.org/10.31979/etd.w6nf-ng5a

https://scholarworks.sjsu.edu/etd_theses/79

This Thesis is brought to you for free and open access by the Master's Theses and Graduate Research at SJSU ScholarWorks. It has been accepted for inclusion in Master's Theses by an authorized administrator of SJSU ScholarWorks. For more information, please contact scholarworks@sjsu.edu. 


\section{INFORMATION TO USERS}

The most advanced technology has been used to photograph and reproduce this manuscript from the microfilm master. UMI films the text directly from the original or copy submitted. Thus, some thesis and dissertation copies are in typewriter face, while others may be from any type of computer printer.

The quality of this reproduction is dependent upon the quality of the copy submitted. Broken or indistinct print, colored or poor quality illustrations and photographs, print bleedthrough, substandard margins, and improper alignment can adversely affect reproduction.

In the unlikely event that the author did not send UMI a complete manuscript and there are missing pages, these will be noted. Also, if unauthorized copyright maierial had to be removed, a note will indicate the deletion.

Oversize materials (e.g., maps, drawings, charts) are reproduced by sectioning the original, beginning at the upper left-hand corner and continuing from left to right in equal sections with small overlaps. Each original is also photographed in one exposure and is included in reduced form at the back of the book.

Photographs included in the original manuscript have been reproduced xerographically in this copy. Higher quality 6" $\times$ 9" black and white photographic prints are available for any photographs or illustrations appearing in this copy for an additional charge. Contact UMI directly to order.



University Microfilms Internatıonal

A Bell \& Howell Information Company 

A hydrogeological investigation of ground water recharge near the drainage retention basin, Lawrence Livermore National Laboratory, Livermore, California

\author{
Toney, Kenneth Charles, M.S.
}

San Jose State University, 1990 







\section{NOTE TO USERS}

THE ORIGINAL DOCUMENT RECEIVED BY U.M.I. CONTAINED PAGES WITH SLANTED PRINT. PAGES WERE FILMED AS RECEIVED.

THIS REPRODUCTION IS THE BEST AVAILABLE COPY. 


\title{
A HYDROGEOLOGICAL INVESTIGATION OF GROUND WATER RECHARGE \\ NEAR THE DRAINAGE RETENTION BASIN, LAWRENCE LIVERMORE NATIONAL LABORATORY, LIVERMORE, CALIFORNIA
}

\begin{abstract}
A Thesis
Submitted to the Department of Geology San Jose State University

In Partial Fulfillment of the Requirements for the Degree Master of Science
\end{abstract}

by

Kenneth Charles Toney August, 1990 
APPROVED FOR THE DEPARTMENT OF GEOLOGY



APPROVED FOR THE UNIVERSITY






\section{ACKNOWLEDGMENTS}

Funds and technical support for this thesis were generously given by the Ground Water Project and the Environmental Quality Verification Program of the Lawrence Livermore National Laboratory, Livermore, California. Many individuals have offered valuable insights and have made this thesis possible. I would particularly like to express my appreciation to my thesis advisory committee, June Oberdorfer, Marshall Maddock, and Fredric Hoffman, for their guidance and assistance. Robert Buddemeier, Mike Ruggieri, Bern Qualheim, Don Homan, William Mcconachie, Chris Johnson, and Kim Heyward of Lawrence Livermore National Laboratory contributed to the presentation and scientific validity of this thesis. Gerald Duarte, Richard Ambrose, and Dave White assisted with invaluable field support. Mike Dresen, Robert Devany, and Eric Nichols of Weiss Associates, Inc. provided inspiration in interpreting hydrogeological data.

My best wishes go to Richard Landgraf, of Weiss Associates, who developed a computer model of the ground water recharge at the drainage retention basin. I am grateful for the patience, encouragement, and support of my wife and family which has carried me through the many and long trials of writing this thesis. 
TABLE OF CONTENTS




TABLE OF CONTENTS (continued)

Ground Water Levels. . . . . . . . . .

Page

Electrical Resistance in Soils . . . . . .

Infiltration Rates . . . . . . .

Saturated Hydraulic Conductivity Rates . .

Tritium Concentrations in Soil . . . . .

Ponding in the Drainage Retention Basin .

Ground Water Flow in the Vadose zone . . .

Ground Water Recharge . . . . . . . .

APPENDIX A: BOREHOLE LOGS . . . . . . .

APPENDIX B: WELL COMPLETION AND CONDUCTIVITY DATA

APPENDIX C: HYDROGRAPHS . . . . . . . . . . . APPENDIX D: RESISTANCE GRAPHS, SEPTEMBER 26, 1985
TO OCTOBER 1,1986 . . . .

APPENDIX E: SOIL RESISTANCE RELATED TO THE FEBRUARY 11-19, 1986 STORM ..... 202

Introduction . . . . . . . . . . . 202

Initial Wetting (February 12-16) . . . . . 234

Ground Water Redistribution (February 16-24) 238

APPENDIX F: DOUBLE-RING INFILTRATION DATA • . . . 240

APPENDIX G: TRIAXIAL PERMEAMETER DATA . . . . . 250 
Figure

1. General Infiltration Rate-Time Relationship. .

2. Map of San Fransisco Bay Area with the Location of LLNL . . . . . . . . . 9

3. Major Surface Drainages near LINL . . 11

4. Simplified Geologic Map of the Livermore Valley Area . . . . . .

5. Regional Ground Water Basin in the Livermore valley . . . . . . .

6. Water Table Configuration in the vicinity of LINL in the Fall of 1981 .

7. Single-Valued Characteristic curves for Three Soils ....... 8. Site Plan of the Drainage Retention

9. Location of Monitor Wells at ILNL . .

10. Rain Distribution During the 1985-86 Water Year. .

11. Surface Drainage Patterns near the Drainage Retention Basin and the Southeast Portion of LLNL 12. Watershed of the Drainage Retention
Basin . . . . . . . . . . .

13. Depth of Ponding in the Drainage Retention Basin During the study Period 14. Pond Volume as a Function of the Depth
of Ponding . . . . . . . .

15. Locations of Cross-Sections

16. Cross-section $\mathrm{A}-\mathrm{A}^{\prime}$. . . . . . . .

17. Cross-section ${\mathrm{B}-\mathrm{B}^{\prime}}^{\prime} . . . . . . . .$. 


\section{LIST OF ILLUSTRATIONS (continued)}

Figure

Page

18. Cross-Section $\mathrm{C}-\mathrm{C}^{\prime}$. . . . . . . . . 59

19. Hydrograph of LR-4-P, MW-10A, and MW-119 66

20. Monthly Rainfall and Hydrograph of

MW-10A, 1980 to 1985 ......... 68

21. Correlation Between Annual Precipitation and Ground Water Fluctuation at MW-10A 69

22. Hydrograph of MW-119, MW-10A, and MW-142 70

23. Water Level Rise as a Function of



24. Contour Map of Ground Water Elevation Change, February 15 to April 15, 1986

25. Storm Events and Soil Resistance at a Depth of 2 Feet in $\mathrm{LR}-2-\mathrm{R}$. . . . .

26. Soil Resistance near a Depth of 30 Feet

27. Ponding and Soil Resistance at a Depth 13.5 Feet in LR-1-R

28. Soil Resistance at a Depth of 21 Feet

29. Wetting Front Propagation at LR-3-R Due to the october 20-21, 1985 storm.

30. Wetting Front Propagation at $L R-2-R$ Due to the January 28-February 4, 1986
Storm ..............

31. Soil Resistance at the Depths of 30.3 , 39 , and 47 Feet in $L R-1-R$....

32. Soil Resistance at the Depths of 30.5 , 39.5, and 48.5 Feet in $L R-2-R$...

33. Soil Resistance at the Depths of 13.5, 22 , and 30.3 Feet in $L R-1-R$. . 


\section{LIST OF ILLUSTRATIONS (continued)}

Figure

Page

34. Moisture Conditions and the Propagation of the Wetting Front During the February 11-19, 1986 storm.....

35. Infiltration Rate as a Function of Time

36. Distribution of the Infiltration Rates

37. The Hydraulic conductivity as Untreated Water Replaces Deaired Water... . . 99

38. Profiles of Tritium at LR-4-P and MW-119 101

39. Correlation Between Rainfall and Basin Percolation . •. •. . . . . 105

40. The Creation and Decay of the water Table Mound Following the March 7-15,

41. Approximate Ground Water surface at and near LLNL, April 14-15, 1986... . . 116

42. Log of Borehole LR-1-R . . . . . . . 131

43. Log of Borehole $L R-2-R$. . . . . . . 132

44. Log of Borehole $L R-3-R$. . . . . . . 133

45. Log of Piezometer LR-4-P . . . . . . 134

46. Hydrograph of $\mathrm{MW}-1$ and $\mathrm{MW}-1 \mathrm{~A}$. . . . 138



48. Hydrograph of $\mathrm{MW}-4$. . . . . . . . 140

49. Hydrograph of $\mathrm{MW}-5$ and $\mathrm{MW}-5 \mathrm{~A} . . . . . \quad 141$

50. Hydrograph of $\mathrm{MW}-7$. . . . . . . . 142

51. Hydrograph of $\mathrm{MW}-8$. . . . . . . . 143

52. Hydrograph of MW-10A . . . . . . . 144 


\section{LIST OF ILLUSTRATIONS (continued)}

Figure

53. Hydrograph of $\mathrm{MW}-12$. . . . . .

Page

54. Hydrograph of $\mathrm{MW}-17$ and $\mathrm{MW}-17 \mathrm{~A} . .$.

55. Hydrograph of $\mathrm{MW}-18$ and $\mathrm{MW}-204$...

56. Hydrograph of $\mathrm{MW}-19$

58. Hydrograph of MW-105 . . . . . . . 150

59. Hydrograph of MW-106 . . . . . . . 151

60. Hydrograph of $\mathrm{MW}-107$. . . . . . . 152

61. Hydrograph of MW-111 . . . . . . . 153

62. Hydrograph of $\mathrm{MW}-112$. . . . . . . 154

63. Hydrograph of $\mathrm{MW}-113$. . . . . . . 155

64. Hydrograph of $\mathrm{MW}-114$. . . . . . . 156

65. Hydrograph of $\mathrm{MW}-116$. . . . . . . 157

66. Hydrograph of MW-117 . . . . . . . 158

67. Hydrograph of MW-119... . . . . . 159

68. Hydrograph of $\mathrm{MW}-141$. . . . . . . 160

69. Hydrograph of $\mathrm{MW}-142$. . . . . . . 161

70. Hydrograph of MW-146. . . . . . . . 162

71. Hydrograph of $\mathrm{MW}-147$. . . . . . . 163

72. Hydrograph of $\mathrm{MW}-148$. . . . . . . 164

73. Hydrograph of $\mathrm{MW-205}$. . . . . . . . 165

74. Hydrograph of $\mathrm{MW}-206$. . . . . . . 166

75. Hydrograph of $\mathrm{MW}-207$. . . . . . . 167 


\section{LIST OF ILLUSTRATIONS (continued)}

Figure

Page

76. Hydrograph of MW-252 . . . . . . . 168

77. Hydrograph of MW-255 . . . . . . . 169

78. Hydrograph of $\mathrm{MW}-256$. . . . . . . 170



80. Hydrograph of $\mathrm{MW}-258$. . . . . . . 172



82. Hydrograph of LR-4-P . . . . . . . 174

83. Hydrograph of $\mathrm{TB}-11$ and $\mathrm{TB}-11 \mathrm{~A} . . .+175$

84. Hydrograph of 7D2 . . . . . . . . 176

85a-h. Soil Resistance in LR-1-R, september 26, 1985 to October 1,1986 . . . . . 177

86a-h. Soil Resistance in LR-2-R, September 26,1985 to October 1,1986 .

87a-i. Soil Resistance in LR-3-R, September 26, 1985 to October 1,1986 . . . . . 193

88a-h. Soil Resistance in $L R-1-R$, February 10, 1986 to March 3, 1986 . . . . . . 203

89a-h. Soil Resistance in $L R-2-R$, February 10, 1986 to March 3, 1985 . . . . . . 211

90a-i. Soil Resistance in LR-3-R, February 10, 1986 to March 1, 1986 ......

91a-e. Wetting Front Between $L R-1-R$ and LR-3-R During the February 11-19, 1986

92. Onset of Drying Between $L R-1-R$ and IR-3-R Following the February 11-19, 93a-b. Infiltration Rate near MW-119 ... 


\section{LIST OF ILLUSTRATIONS (continued)}

\section{Figure}

Page

94a-b. Infiltration Rate near $L R-1-R$. . . 242

95. Infiltration Rate near the Northeast Corner of the Basin ......... 244

96a-b. Infiltration Rate in the Eastern

Portion of the Basin......... 245

97. Infiltration Rate in the Southeastern Portion of the Basin........ . 247

98. Infiltration Rate near LR-4-P . . . . 248

99. Infiltration Rate near LR-2-R . . . 249

100. Hydraulic Conductivity in soil sample LRIR-40 • . • • . . . . . . . 250

101. Hydraulic Conductivity in soil sample LR2R-30.5 •. . . . . . . . . . 251 102. Hydraulic Conductivity in soil sample 
Table

Page

1. Precipitation and Estimated Runoff in the on-site watershed of the Drainage Retention Basin During the 1985-86

Water Year . . . .

2. Pond Volume Loss After Each Storm of

the 1985-86 Water Year........

3. Summer and winter Soil Resistance According to Soil Classification ...

4. Saturated Hydraulic conductivities in Soil Samples from the Drainage Retention Basin

5. Tritium Concentrations in Soil beneath and near the Drainage Retention Basin

6. A Comparison Between the Observed Pond Volume Loss and Calculated on-site Runoff .

7. Hydraulic Conductivity and Well Completion of Selected Wells at LLNL . 


\begin{abstract}
A HYDROGEOLOGIC INVESTIGATION OF THE RATES AND EFFECTS OF GROUND WATER RECHARGE NEAR THE DRAINAGE RETENTION BASIN LAWRENCE LIVERMORE NATIONAL IAABORATORY
\end{abstract}

\author{
by Kenneth c. Toney
}

This thesis was conducted over the 1985-86 water year to determine the rates and effects of ground water recharge from a man-made drainage retention basin, located at the Lawrence Livermore National Laboratory, Livermore, CA.

The relationships between rainfall, surface runoff, ponding, infiltration, wetting front migration, and ground water recharge were characterized. Data from a network of soil resistance cells indicated that moisture flux in the vadose zone is dependent on the distribution of permeable soils, horizontal distance to ponding, and antecedent moisture conditions. Water levels in wells within and near the basin fluctuated up to 25 feet after major storms and rose within 2 to 3 days after the onset of most storms. By the end of the rainy period, approximately 75 acre-feet of water was recharged and the water table mound had propagated radially at least 2000 feet from the basin. 


\section{INTRODUCTION}

\section{Purpose}

This study investigates and quantifies the relationships between rainfall, ponding, infiltration, and ground water recharge in the vicinity of the four acre drainage retention basin at the center of the Lawrence Livermore National Laboratory (LLNL). The main focus of this study is on the ground water flow patterns and recharge processes that develop due to intermittent ponding inside the basin.

Ground water recharge is an important process in a ground water system. When water is discharged or pumped from a ground water system the ground water supply is depleted unless mitigated by recharge or by subsurface inflow. Several water conservation districts including Zone 7 of the Alameda county Flood Control and Water Conservation District (which regulates the water supply for Livermore valley) have initiated artificial ground water recharge programs to maximize their ground water resources. Ground water is a valuable resource and allows greater flexibility in the event of a drought. Ground water recharge can alleviate the threat of poor quality ground water by increasing the supply of good quality water, diluting contaminant concentrations, and 
flushing the ground water system through increased outflows.

During the study period from October 1985 to october 1986, rainfall, surface waters, and ground water near the intermittent pond were monitored. Ground water movement in both the vadose and saturated zones was traced through a network of soil resistance cells and monitor wells, respectively. Sediments on and below the basin floor were analyzed for their permeability and homogeneity through infiltration tests, exploratory borings, and core analysis. The tritium activity in recovered soil samples identified the presence and approximate distribution of recently (post 1952)

infiltrated water. Geologic cross-sections of the basin area were constructed, based on hydrologic data and borehole logs to show the geologic factors at depth which control ground water movement.

The results of this study aid LLNL personnel in assessing the impact upon the environment resulting if the drainage retention basin were modified by changing either the basin's storage capacity or percolation characteristics. They permit: 
1) estimation of recharge from rainfall and pond size data,

2) prediction of the effects of contaminants in surface runoff on ground water quality,

3) determination of long-term ground water flow patterns, and

4) formation of a data base for better understanding and modeling of recharge and unsaturated flow beneath an intermittent pond.

\section{Previous studies}

Reconnaissance of the geology and ground water resources of Livermore Valley was initially performed by the Califoria Department of Water Resources (CDWR, 1967 and 1974). The drainage retention basin was first recognized as a significant source of ground water recharge by stone et al. (1982). Carpenter et al. (1980, 1982, and 1984) evaluated the geologic, hydrologic, and seismological conditions at LINL through surface mapping, exploratory trenching, geophysical surveys, exploratory drilling, and monitoring well installation and sampling. Additional exploratory drilling in the drainage retention basin, near the East Traffic circle approximately 300 feet east of the drainage retention basin, and at other locations at LLNL 
was documented by Carpenter (1984). Since late 1984, investigation of the ground water conditions at and near LLNL, as reported in numerous monthly progress reports, has been an ongoing task of the LLNL Environmental Restoration Division (formerly, the LLNL Ground Water Project). Logs of boreholes and monitor wells completed by the LLNL Environmental Restoration Division are included in Weiss Associates (1985) and Qualhiem (1988). The infiltration rate over time under prolonged submergence varies (fig. 1) due to combined biological and nonbiological clogging (Scalmanini and scott, 1979). An initial decrease in the infiltration rate has been attributed to swelling, settling, and dispersion of the soil due to the application of water (Allison, 1947). Following this an increasing infiltration rate is observed as air entrapped in soil pores is expelled and the moisture content is increased. These two processes are active only during a relatively short period--generally less than two months (Scalmanini and Scott, 1979). A long term exponentially decreasing recharge rate is observed as suspended solids deposition and biological activity clog the interstitial pores at the soil-water interface. This last process may significantly affect the economics of a recharge operation and periodic maintenance is often warranted to 


remove clogged soil. If the underlying soil is as pervious as that at the surface, then the water transmitting properties of the uppermost few inches of soil will determine the recharge efficiency of the site. Richter and Chun (1959) documented 276 artificial recharge projects in California. of these, 149 used basins to receive water diverted from natural sources or to dispose of treated wastewater. Infiltration rates varied between less than 0.3 and 9.5 feet/day ( $<0.1$ and $2.9 \mathrm{~m} /$ day) at 15 representative recharge basins in the United States (Todd, 1988). The City of Holister, Califoria, has annually applied 51 feet $(15.4 \mathrm{~m})$ of treated wastewater to 20 infiltration basins since the 1940's (Olsen, 1978). These basins were intermittently flooded for 1 to 2 days every 2 to 3 weeks and occasionally disked to remove wastewater solids from the basin surface. No change in the infiltration rate from these basins has been observed over the years. Periodic maintenance of an infiltration basin is commonly performed to enhance the operation of a recharge facility. Wet-dry cycles, removal of sediments, aeration of soil, maintenance of landscape, and reduction of biological life are common forms of such maintenance (Scalmanini and scott, 1979). Alternating wetting and drying periods generally 
furnishes a greater total recharge than does continuous flooding (Todd, 1988). Removal of fine sediments from the basin floor can improve the infiltration rate. However, care should be taken to minimize soil compaction during sediment removal. Anaerobic digestion causes a steeper decline in the infiltration rate than aerobic digestion because anaerobic bacteria are less efficient in utilizing detrital material (Scalmanini and Scott, 1979). Soil aeration, cold temperatures, low concentrations of dissolved and suspended solids in the influent water, and prevention of aerobic overpopulation delay the inception of anaerobic conditions.

The geometry of the recharge basin and the ground slope also influence the infiltration rate. Percolating water moves laterally as well as vertically away from the basin (U.S. Department of Agriculture, 1970). Thus for small ponds, the greatest infiltration rate is observed when the perimeter of the pond is large in relation to the area. Rectangular shaped basins would have greater infiltration rates than circular or square basins with the same area. Lateral flow becomes less important as the basin becomes larger and a greater percentage of the infiltration occurs through the basin floor. Wave action often prevents the accumulation of fines on the sidewalls of a basin and may make these 
areas relatively more effective in infiltrating water. Results from test ponds indicate that the infiltration rate increases as the slope of the basin floor steepens (Martin and Fagundes, 1972).

\section{Site Description}

LLNL is located 40 miles $(65 \mathrm{~km})$ east of San Francisco in the central California coast Ranges. LLNI occupies 800 acres (parts of sections 1, 2, and 11 and all of section 12, T2S, R3E, Mount Diablo Base and Meridian) on East Avenue three miles $(5 \mathrm{~km})$ east of the city of Livermore, California (fig. 2). The Laboratory lies on the east-central portion of the Livermore Valley floor close to the Altamont Hills.

The Livermore Valley is an east-west structural and topographic depression that trends nearly perpendicular to the north-northwest lineations of the Central California coast Ranges. The valley floor is approximately 16 miles $(25 \mathrm{~km})$ long and averages 7 miles $(11 \mathrm{~km})$ in width. It has a gentle westwardly gradient from an elevation above sea level of approximately 700 feet $(215 \mathrm{~m})$ at its eastern margin to 295 feet $(90 \mathrm{~m})$ at the drainage exit in the Arroyo de Laguna southwest of Pleasanton (Stone, et al., 1982). The hills surrounding the Livermore Valley range in elevation from 1200 to 




Figure 2. Map of San Francisco Bay Area with the location of Lawrence Livermore National Laboratory (LLNL)
(Stone et al., 1982). 
3000 feet ( 365 to $915 \mathrm{~m}$ ) above sea level and form a watershed of approximately 400 square miles $\left(1000 \mathrm{~km}^{2}\right)$ (CDWR, 1974).

The ground surface at LINL is flat and slopes gently at a 1-3\% gradient to the northeast. Ground surface elevations range from 675 feet $(206 \mathrm{~m})$ to 570 feet $(174 \mathrm{~m})$ above sea level at the laboratory's southeast corner and northwest corner, respectively. A large portion of the surface area of the LINL site is covered by asphalt and buildings except in the northeast section. Surrounding LINL are grassy rolling hills to the south and east, and a mixture of urbanized and relatively undeveloped flat land to the north, west, and southwest.

The southwest portion of LINL is drained by the Arroyo Seco while the northern and eastern parts of LLNL are drained by the Arroyo Las Positas (fig. 3). The four acre drainage retention basin is located at the center of the laboratory. The basin, excavated and progressively enlarged between 1972 and the early 1980 's, receives surface runoff from 120 acres in the southeastern portion of LLNL and 880 acres off-site. A portion of the off-site flow is diverted to the basin at the east entrance to LINL (near the middle of LLNL's eastern boundary) during near flood conditions. When 




Figure 3. Major surface drainages near LINL include the Arroyo Las Positas and Arroyo Seco. The drainage retention basin is located near the center of the laboratory (modified from University of California, 1986). 
the water in the basin exceeds 28 acre-feet (the basin's storage capacity) it overflows at the north edge of the basin to eventually join the Arroyo Las Positas.

The Central California coast Range has a

"Mediterranean scrub woodland" climate. This climate is characterized by warm, sunny summers and a rainy season between October and April. Rainfall near ILNL averages around 15 inches $(38 \mathrm{~cm}$ ) per year, but has ranged from around 6 inches $(15 \mathrm{~cm})$ during the drought years of 1975-76 and 1976-77 to as much as 34 inches $(87 \mathrm{~cm})$ during the 1982-83 water year (Zone 7 files). The mean annual temperature in Livermore is $59^{\circ} \mathrm{F}\left(12.5^{\circ} \mathrm{C}\right)$ (Stone et al., 1982). Moderate winds are common throughout the year at LLNL due to modified coastal air moving through the passes at the west and east ends of Livermore Valley (U.S. Dept. of Energy, 1982). The potential evapotranspiration per year at LLNL is estimated at around 28 inches $(72 \mathrm{~cm})$ while the actual amount in unirrigated areas is approximately 9 inches $(23 \mathrm{~cm})$ due to the shortage of available water during the dry season (U.S. Dept. of Agriculture, 1966). Potential evapotranspiration rates range from less than one inch $(2.5 \mathrm{~cm})$ per month in the winter to over six inches (15 cm) per month in the summer (CDWR, 1974). 
Geology of LLNL and Adjacent Areas

The geology of LLNL and adjacent areas has been mapped (Huey, 1948; Herd, 1977; Dibblee, 1980; and Sweeney and Springer, 1981) and assessed for geologic hazards (Carpenter et al., 1980, 1982, 1984). The Pliocene to Holocene lacustrine and fluvial deposits in the Livermore area exhibit minor folding, rest unconformably upon deformed Tertiary sedimentary rocks, and are downwarped towards the valley center. This structural evidence suggests a synorogenic depositional origin for these terrestial Pliocene and younger sediments (Carpenter et al., 1980, 1984).

The late Plio-Pleistocene Livermore Formation occurs in the hills south of the Livermore Valley and under most of the valley floor. The Livermore Formation is up to 4000 feet $(1200 \mathrm{~m})$ thick and is subdivided into two members. The lower unit consists of predominantly bluish and greenish gray claystone with some interbeds of weakly indurated pebble conglomerate or sandstone; the upper unit consists of brown and light reddish gray pebble to cobble gravel with minor to major amounts of brown silt, clay, and claystone (Dibblee, 1980). At LLNL the contact between the upper and lower Livermore members appears to be a buried topographic 
surface with considerable relief (Dresen and Nichols, 1986). The elevation of this contact above sea level ranges from $550(167 \mathrm{~m})$ at the southeast corner of LINL to roughly 300 feet $(91 \mathrm{~m})$ at the eastern boundary of LINL. In general this contact dips to the northwest and lies between 20 and over 300 feet ( 6 to over $91 \mathrm{~m}$ ) below the ground surface. Near the northern edge of the drainage retention basin at monitor well MW-351, the contact is encountered at a depth of 171 feet $(52 \mathrm{~m})$ which is an elevation of 440 feet $(134 \mathrm{~m})$ above sea level. The upper member of the Livermore Formation grades upward into nearly identical alluvial sediments of late Pleistocene and Holocene age.

The Quaternary stratigraphy at the eastern end of the valley is poorly defined and complex due to active local uplift and the limited depositional capabilities of the Arroyo Seco and Arroyo Las Positas (Carpenter et al., 1984). At LLNL the alluvial sediments are very heterogeneous and consist of interlayered and interlensed clays, silts, sands, and gravels. Correlation of individual layers encountered at depth in this area is often a speculative task due to rapid lateral and vertical facies changes. This heterogeneity is the result of deposition by small, laterally shifting arroyos. The depositional gradient of the upper 
Iivermore and younger sediments at IINL generally appears to $\operatorname{dip} 1.0^{\circ}$ to $1.5^{\circ}$ to the northwest, i.e., parallel to the ground surface (Dresen and Hoffman, 1986; Dresen and Nichols, 1986). At LLNL low net sedimentation rates of about $0.1 \pm 0.03$ feet $/ 1000$ years $(3.0 \pm 0.9 \mathrm{~cm} / 1000$ years) are indicated by soil profiles and from relative and absolute age data (Carpenter et al., 1984).

The alluvium at the eastern end of the Livermore Valley is bounded on the southeast by the Las Positas Fault and on the east by the Greenville Fault zone (fig. 4). Both faults are active strike slip faults with some vertical component of movement. Vertical movement sense along the Las Positas Fault is north-side down. Vertical movement sense along the Greenville Fault zone is west-side down (Carpenter et al., 1982 and 1984). Non-water bearing rocks outcrop east of the Greenville Fault zone and the clayey lower member of the Livermore Formation outcrops in the series of hills between the north and south branches of the Las positas Fault (Carpenter et al., 1984). 




Figure 4. Simplified geologic map of the Livermore Valley Area (Carpenter et al., 1984). 
Mocho I Subbasin

The alluvial basin east of the city of Livermore is called the Mocho I Subbasin. The Mocho I Subbasin is expanded eastward in this thesis to the eastern margin of Livermore Valley. Previously, the California Department of Water Resources (CDWR, 1966, and 1974) hypothesized that the northwest trending carnegie and Tesla Faults continued through the valley's alluvial deposits and acted as hydraulic barriers between several subbasins near LLNL (fig. 5). This hypothesis is unlikely because no surface expressions of these faults were found to disrupt the valley floor (Carpenter et al., 1984), and the water table elevations found in this region appear to be continuous (fig. 6). The Las Positas fault acts as a substantial hydrologic barrier (Stone et al., 1982) and forms the southern boundary of the Mocho I subbasin.

Ground water in the Mocho I subbasin is usually of good quality, used for industrial, domestic, and limited agricultural purposes, and pumped from unconfined and leaky confined water bearing zones (CDWR, 1974; Sorenson et al., 1985). The water table under LLNL and in most of the Mocho I Subbasin generally slopes $1^{\circ}$ to the west or northwest. The piezometric surface or water table 











Figure 6. Water table conflguration super-imposed on the surface topography in the vicinity of LLNL in the fall of 1981. Faults mapped by Dibblee (1980)(modifled from
Stone et. al. 1982) 
is found at 30 and 145 feet ( 9 and $44 \mathrm{~m}$ ) below the ground surface at the northwest and southeast corners of LINL respectively. The potentiometric head in the lower member of the Livermore Formation is as much as 80 feet $(24 \mathrm{~m})$ lower than in the overlying sediments (Dresen and Nichols, 1986). The downward oriented hydraulic gradient and disequilibrium between the water levels in the lower member of the Livermore Formation and the overlying sediments is probably due to a combination of ground water mining in the previous decades and the low vertical permeability of the lower member of the Livermore Formation. An apparent depression of up to 20 feet $(6 \mathrm{~m})$ in the water table exists in the southeast portion of LINL where the lower member of the Livermore Formation occurs as the first water-bearing zone (Stone et al., 1982; Dresen and Nichols, 1986).

Ground Water Development and Recharge

Several irrigation and domestic supply wells on Figure $6(1 \mathrm{~N} 1,2 \mathrm{Kl}, 2 \mathrm{RI}, 11 \mathrm{HI}, 11 \mathrm{~J} 1,11 \mathrm{Kl}, 12 \mathrm{~N} 1$, and 14ABI) were completed before 1950 (LINL, 1984). Many other wells in the area are of unknown age. Around 1945 ground water pumpage in the Livermore Valley began to exceed ground water recharge, and water levels declined (Davies, 1981). This decline continued until 1962 when 
the importation of water through the South Bay Aqueduct supplemented Livermore Valley's ground water pumpage. In 1969, Del Valle Reservoir provided an additional water supply source by conserving runoff from the Arroyo Del Valle and storing imported South Bay Aqueduct water. Around 1970 ground water levels began to rise due to reduced pumpage of ground water, recycling of waste water, and artificial ground water recharge (CDWR, 1974).

From 1962 to 1973 zone 7 of the Alameda county Flood Control and Water Conservation District (Zone 7) periodically released water from the South Bay Aqueduct into Altamont Creek 2 miles $(3.2 \mathrm{~km})$ north of LLNL. A total of 10,440 acre-feet was released (Zone 7,1983 ). In 1979 and 1980 a total of 1024 acre-feet of water was released from the South Bay Aqueduct into the Arroyo Seco. Stream loss calculations on the Arroyo seco indicate that $80 \%$ ( 800 acre-feet) of the total amount released recharged the Mocho I. Subbasin (Zone 7, 1981). Artificial recharge at the eastern end of the valley was discontinued after this period due to very shallow ground water conditions near the Las Positas Spring 1.6 miles $(2.6 \mathrm{~km})$ west northwest of LLNL. Zone 7 also released over 70,000 acre-feet of water from 1969 to 1982 into the Arroyo Mocho and Arroyo Del Valle from the 
South Bay Aqueduct and Del Valle Reservoir (Zone 7, 1983, and 1985).

Stone et al. (1982) conclude, from tritium and

water level data, that surface water near LLNL periodically infiltrated from the Arroyo Las Positas, Arroyo Seco, and the drainage retention basin and recharged the saturated zone. Hydrographs of LLNL monitor wells $M W-1, M W-2, M W-5$, and $M W-10 A$ from the Fall of 1981 to Fall 1982 indicate that ground water recharge occurred at these wells after storm activity. Further evidence that the basin and two arroyos are sources of recharge to the saturated zone was indicated by the elevated tritium concentrations in soil and/or ground water from these four wells. The elevated tritium concentrations are primarily due to discharges of tritium to the atmosphere from LLNL's Gaseous Chemistry Facility since the 1950's.

The hydrographs of zone 7 monitor wells $11 \mathrm{~J} 2$ and $14 \mathrm{A3}, 0.25$ miles $(0.4 \mathrm{~km})$ away from the Arroyo seco, show a water table rise of 30 feet $(9 \mathrm{~m})$ between 1979 and 1982 in response to recovery from the 1975-77 drought years and to the water released into the Arroyo Seco by the zone 7 artificial recharge program (stone et al., 1982). A comparison of water levels between the Falls of 1980 and 1985 at MW-2, MW-4, MW-5, MW-7, 
MW-10A, $M W-12$, and $M W-17, M W-18$, and $M W-19$ indicates a 10 to 25 foot $(3.0$ to $7.6 \mathrm{~m})$ rise under most of LLNL in the five years preceding this study (Carpenter et al., 1982; Weiss Associates, 1985).

Ground Water Flow and Hydraulic conductivity

This subsection reviews some basic concepts in ground water hydrology. Darcy's law is fundamental for the analysis of ground water flow rates near the drainage retention basin. For saturated porous media Darcy's law can be written as:

$$
v=\frac{-k(d h / d l)}{n}
$$

where;

$$
\begin{aligned}
& v=\text { average linear velocity }\left(\mathrm{LT}^{-1}\right) \\
& \mathrm{n}=\text { effective porosity }() \\
& \mathrm{k}=\text { hydraulic conductivity }\left(\mathrm{LT}^{-1}\right) \\
& \text { dh/dl = hydraulic gradient }(,)
\end{aligned}
$$

In the saturated zone, the hydraulic conductivity is constant for a given soil and the ground water velocity is proportional to the hydraulic gradient and can be calculated relatively easily. The hydraulic gradient is 
the slope of the potentiometric surface or the water table in the case of an unconfined water-bearing zone. The hydraulic conductivity can be measured through slug and/or pump tests (Dresen et al., 1987). The effective porosity can can be measured in bulk density tests (Ruggieri and stone, 1983).

In the unsaturated zone, the hydraulic conductivity and the moisture content are functions of the pressure head. The pressure head in the unsaturated zone is negative and can be thought of as the tension-suction which holds water in the soil pores. In the unsaturated zone, the hydraulic conductivity of a coarser grained or more pervious soil may be less than that of a finer grained or less pervious soil (fig. 7). The simplified characteristic curves shown on Figure 7 indicate that the hydraulic conductivity decreases with decreasing pressure head and moisture content. 



Figure 7. Single-valued characteristlc curves for three hypothetlcal solls. (a) uniform sand; (b) silty sand; (c) slity clay (Freeze and Cherry, 1979). 
METHODS

\title{
Precipitation
}

\author{
Rainfall was collected during the study period \\ (i.e., the 1985-86 water year or from October 1, 1985, \\ to september 31,1986 ) in a rain gauge located near the \\ northeast corner of LLNL. The amount of rainfall was \\ measured to both the nearest 0.005 inch and nearest 0.1 \\ millimeter at each visit (usually 2 or 3 times a week). \\ Generalized observations of the temperature, wind, cloud \\ cover, and flow in drainage channels were also recorded \\ during each visit.
}

\section{Pond Size}

The area of ponded water in the drainage retention basin was measured several times a week. Proposed borehole locations and basin perimeter were surveyed with a laser alidade on August 12, 1985 (fig. 8). The elevation of the pond surface was measured at each visit with a measuring tape to the nearest 0.01 of a foot $(0.3$ $\mathrm{cm})$ above the surveyed boreholes and/or above the lowest point in the basin. If the floor of the basin was inundated, then the pond level was measured by counting the exposed steps on the ladder at LR-4-P. The area of the pond was measured by pacing its perimeter and the 





distance from surveyed locations to the edge of the pond, ploting this data on grid paper, and calculating the area inside the plotted pond.

Drilling, Logging, and Borehole completion

Four exploratory boreholes were drilled by this study in the central portion of the drainage retention basin (fig. 8) during September 3-19, 1985. These borings were drilled using a sIMCo 2800 trailer mounted drill rig and $5.5-$ inch $(14-\mathrm{cm})$ diameter hollow stem augers. Three of the boreholes (LR-1-R, LR-2-R, and IR-3-R) were drilled to approximately 55 feet $(17 \mathrm{~m})$ and completed with a network of paired resistance cells. $L R-4-P$, adjacent to $L R-3-R$, was drilled to 70 feet ( 21 m) and completed as a $1.5-i n c h(3.8-\mathrm{cm})$ inner diameter piezometer.

The geologic logs (Appendix A) of the sediments encountered at depth in the boreholes were based upon the operation of the drill rig, and the properties of the cuttings and recovered soil samples. Cobbles could be detected by poor advancement and a grinding sound from the drill bit. No advancement without the addition of water down the borehole indicated relatively dry, clean, coarse sediments. The fastest progress was made through fine grained soils. A change in the properties 
(especially grain size) of the cuttings helped to locate the contact between sedimentary units.

Standard Penetration Tests were conducted every 10 feet $(3 \mathrm{~m})$, except at $L R-3-R$, to obtain relatively undisturbed soil samples. A split-tube sampler (1.4inch inner diameter) was placed down the center of the hollow stem augers on a solid push rod to the level of the drill bit and then driven with a 140-pound (64-kg) weight falling 2.5 feet $(0.75 \mathrm{~m})$. The density or stiffness of the soil was measured by the number of blows for every 6 inches $(15 \mathrm{~cm})$ of advance during the standard penetration test. The sampler was then recovered, split open, and logged. The soil sample was then stored in a plastic bag and labeled except for a 3 inch $(7.5 \mathrm{~cm})$ sample which was reserved for tritium analysis. The sampler was wiped clean between tests. Each sedimentary unit encountered was classified by Unified Soil classification system and named by its dominant grain size with possibly 1 or 2 additional modifiers (if other grain sizes occur over 12\%) (U.S. Dept. of Interior, 1980). The color, moisture content, degree of stiffness or hardness, and presence of caliche, iron oxide, and manganese oxide were recorded for each unit. Estimates were made of the saturated permeability and distribution of grain sizes. 
Several limitations exist in this study's subsurface geologic logging. The description and thickness of the sedimentary units encountered between the recovered soil samples are of limited accuracy due to mixing of the cuttings by the auger flights. The descriptions of the subsurface are not quantified by geophysical or sieve analysis. The heterogeneous nature of the deposits under LLNL do not allow great confidence in the extrapolation of the geology between boreholes. As an example even though $L R-3-R$ and $L R-4-P$ are only 4 feet $(1.2 \mathrm{~m})$ apart, they appear to have some differences; LR-3-R encountered more cobbles, lacked two thin sedimentary units, and had contacts that were up to 1.5 feet $(0.45 \mathrm{~m})$ different.

Five additional boreholes inside the basin $(D-1$, $D-2, D-3, D-4 B$, and $D-5)$ and three monitor wells near the basin perimeter (MW-10A, $M W-119$, and $M W-351$ ) help to define the geology under the basin (fig. 8). Borehole logs for the D series are included in Carpenter (1984); the $\log$ for MW-1OA is included in carpenter et al. (1982): more recent MW series logs (including MW-119 and $M W-351$ ) are included in Qualhiem (1988). Greater confidence is justified in the accuracy of the geologic logs of the MW series. The MW series wells are generally cored continuously in the saturated zone and 
logged for several geophysical parameters (spontaneous potential, point and lateral resistivity, gamma radiation, and caliper).

\section{Ground Water Levels}

Appendix B lists the completion data and hydraulic conductivity determined in wells located within a 0.5 mile $(0.8 \mathrm{~km})$ radius from the basin as of March 1986. Monitor wells installed within 500 feet of the basin prior to November 1986 are also included in Appendix B. As shown in Appendix B the hydraulic conductivity of permeable sediments at LLNL can vary between 0.33 and $53.6 \mathrm{feet} / \mathrm{day}(0.10$ and $16 \mathrm{~m} / \mathrm{day})$. Monitoring well locations are shown on Figure 9. Water level elevations in monitoring wells are used to generate ground water contour maps. The threat of ground water migration along the length of the borehole between different water-bearing zones has been eliminated by placing at least one foot $(0.3 \mathrm{~m})$ of bentonite above the sand pack and backfilling the borehole with a cement grout containing approximately $5 \%$ bentonite powder. Continuous readings of the depth to water were measured for $I R-4-P$ and $M W-119$ for most of the study period. These measurements were often corroborated by manual soundings with an electric water level meter. 





Water level data at LR-4-P was collected with a bubbler gauge from January 5, 1986 to the end of the study. The bubbler gauge had a 10 foot $(3 \mathrm{~m})$ measuring range and could not be calibrated with manual measurements when the pond was over five feet $(1.5 \mathrm{~m})$ deep. Data from a Stevenson water level recorder on MW-119 was collected from November 20, 1985 to the end of the study. The Stevenson recorder had some problems with occasional clock stoppages and a counter weight wire that hung up during falling water levels.

All wells near LLNL were sounded with an electric water level meter to the nearest 0.01 feet $(0.3 \mathrm{~cm})$ near the middle of every month except for off-site private wells (Webster-Scholten et al., 1987). Wells within a 1500 feet $(450 \mathrm{~m})$ radius from the basin were sounded at least biweekly and more frequently during the rainy season. All of these wells were surveyed and contain a notebook which records the date and activity of each visit.

\section{Resistance Data}

The electrical resistance of soils increases with decreasing moisture content and coarser grained material. The correlation between resistance and moisture content varies from soil to soil and laboratory 
curves developed from disturbed samples often do not show good agreement with the undisturbed counterpart, presumably due to differences in bulk density and altered soil structure (Freeze and Banner, 1970). The advantage of resistance cells over tensiometers is that many more resistance cells can be installed in a borehole than tensiometers as well as to greater depths. Thus a clearer spatial and temporal pattern of the fluctuating moisture content in the vadose zone can be seen with a limited number of boreholes.

The resistance cells (Soiltest MC-360 through MC-367) were installed in pairs in $L R-1-R, L R-2-R$, and LR-3-R at approximately the following depths below the basin floor: $2,5,10,15,20,30,40$, and 50 feet 10.6 , $1.5,3,4.5,6,9,12$, and $15 \mathrm{~m}$ ) (Appendix A). The corrosion resistant soiltest cells are 1 inch by 1.5 inches by 0.125 inches $(2.5 \mathrm{~cm}$ by $3.8 \mathrm{~cm}$ by $0.3 \mathrm{~cm}$ ) and are composed of two metal plates which are separated by a fiberglass binding. The resistance cells were installed in pairs to check the variability in resistance between cells for the same geologic material and to provide a backup in case of a malfunction. The resistance cells were embedded in approximately 6 inches $(15 \mathrm{~cm})$ of electrically neutral, 200 mesh silica flour and sealed above and below with roughly one foot of 
bentonite pellets, except for the 50 foot $(15 \mathrm{~m})$ stations which were not underlain by bentonite. Cement grout was tremmied down the borehole between the resistance stations.

The representativeness of the resistance readings may have been adversely affected by the smearing of cuttings up the sides of the borehole and possibly by inadequate settling time of the silica flour slurry so that some bentonite pellets may have mixed into the silica slurry. In either case the resistance cell would be partially isolated from the soil so that the resistance data would lag behind and attenuate the actual moisture fluctuations in the soil. Everett et al. (1983) reported that "an overnight wait is usually sufficient" to allow the soil moisture to equilibrate with the resistance cell after the passing of a moisture front.

The resistance between the two metal plates inside the resistance cells was measured manually with Soiltest's MC-300A meter one to four times a week between september 22, 1985, and January 13, 1986. The error in these resistance readings may be as much as $10 \%$ since the resistance values were read off of a small logarithmic scale. After January 16, 1986, the resistance cells were measured every 10 minutes and the 
average was recorded every hour by a campbell scientific $21 x$ datalogger. In taking a resistance measurement a short pulse of alternating current was passed between the metal plates so that the nearby material does not become polarized. The resistance was obtained from the electrical signal using a half bridge circuit in the datalogger or by rectifying the signal for indication on a direct current ammeter in the soiltest moisture meter. The resistance measurements from the soiltest moisture meter were generally equal or somewhat smaller in value than the measurement from the datalogger. There are two significant gaps in the datalogger data base; from March 6 to April 4, 1986, where the data tape was accidentally erased, and from August 6-20, 1986, when weak batteries resulted in erroneous readings. Fortunately, resistance readings were written down during 6 visits in the first gap.

Double-Ring Infiltrometer

Percolation rates within the drainage retention basin were determined with a double-ring infiltrometer in accordance with ASTM standards (Lukens, 1981). The ASTM double-ring infiltrometer consisted of two 15-inch $(37-\mathrm{cm})$ high concentric metal cylinders of 5 -inch (15cm) and 1 -foot $(30-\mathrm{cm})$ radii, which were driven 
approximately 4 inches $(10 \mathrm{~cm})$ into the soil with a sledge hammer. Care was taken to disturb the soil as little as possible so that soil more than 0.1 inch (3 $\mathrm{mm}$ ) from the rings was not disturbed. The rings were removed and installed at another location if the soil became too disturbed.

After installing the rings, the soil was temporarily covered with cheese cloth or cardboard to prevent soil scouring during the initial filling of the infiltrometer with water. Depth of ponding inside the rings ranged from 2 to 6 inches ( 5 to $15 \mathrm{~cm}$ ). The higher heads were used over fine grained soils. During the test the infiltrometer was covered with a tarpaulin between observations in order to minimize evaporation. A constant level of ponding was maintained with a Mariotte flow meter for the inner ring and periodic additions as required to the outer ring. The error in the Mariotte flow meter was two per cent (Constantz, 1983). The outer ring acted as a hydraulic buffer to prevent divergent, horizontal flow from the inner ring. The downward percolation rate was calculated from the following equation: 


$$
P=R_{i} / C_{i}
$$

where;

$$
\begin{aligned}
& P=\text { percolation rate }\left(L T^{-1}\right) \\
& R_{i}=\text { flow rate of water into the inner ring } \\
& \quad\left(\mathrm{L}^{3} \mathrm{~T}^{-1}\right) \\
& C_{i}=\text { cross-sectional area of the inner ring } \\
& \left(\mathrm{L}^{2}\right)
\end{aligned}
$$

A falling head approach was used in areas with very low or very high percolation rates where it was inconvenient to use the Mariotte flow meter. In this case:

$$
\mathrm{P}=\mathrm{H}_{\mathrm{i}}
$$

where;

$$
\begin{aligned}
& P=\text { percolation rate }\left(L T^{-1}\right) \\
& H_{i}=\text { head loss from the inner ring per unit time } \\
& \left(L T^{-1}\right)
\end{aligned}
$$


In areas of rapid percolation, the rings were refilled several times to the initial level and then allowed to drain for short periods. In areas of slow percolation, the infiltrometer was allowed to drain for several days. The volume of water required to fill the inner ring to the initial level was used to check the measured head loss.

\section{Triaxial Permeameter}

A triaxial permeameter, manufactured by BrainhardKillman Drill Company, was used to measure the hydraulic conductivity of three core samples collected under the drainage basin. These soil samples consisted of sandy silts, from a depth of 40 feet $(12 \mathrm{~m})$ in $I R-1-R$ and from a depth of 55 feet $(17 \mathrm{~m})$ in $L R-4-P$, and a loose, fine grained sand, from a depth of 30.5 feet $(9 \mathrm{~m})$ in LR-2-R. The hydraulic conductivity (K) was calculated by applying the following derivation of Darcy's law: 
where;

$$
\mathrm{K}=\frac{\mathrm{QL}}{\mathrm{AH}}
$$

$$
\begin{aligned}
& \mathrm{K}=\text { hydraulic conductivity }\left(\mathrm{LT}^{-1}\right) \\
& \mathrm{Q}=\text { steady volumetric discharge }\left(\mathrm{L}^{3} \mathrm{~T}^{-1}\right)
\end{aligned}
$$$$
L=\text { length of the core sample ( } L \text { ) }
$$$$
A=\text { cross-sectional area of the sample }\left(L^{2}\right)
$$$$
H=\text { difference in head across the sample (I) }
$$

Prior to placing the piece of core in the permeameter the sample was weighed and its length was measured. The sample was then sandwiched between two porous plates and inserted into a latex membrane which confined the flow of water through the interior of the sample. The loose sandy sample was packed into a metal cylinder to keep the sample in the cylindrical shape assumed in the above equation.

Each permeameter sample was saturated with deaired water before testing, because trapped air in a sample will reduce the hydraulic conductivity. The samples were placed under vacuum and allowed to saturate until either no bubbles were noticed in the outflow line or more than one week had passed. During the test the discharge was either measured at the end of the outflow tube with a $500 \mathrm{ml}$ graduated cylinder for the sandy 
sample or in the $25 \mathrm{ml}$ inflow pipette for the two silty samples. A confining pressure of approximately 5 psi greater than that in the inflow line was placed on the latex membrane to prevent piping along the samples' edge.

\section{Tritium Analysis}

Tritium $\left({ }^{3} \mathrm{H}\right)$ has a half-life of 12.4 years and is a useful tracer of the migration of young ground water in the subsurface (Gvirtzman and Magaritz, 1986). Tritiated water is considered to be a conservative tracer and does not behave significantly different from water except for its radioactivity. Water from the atmosphere (e.g., rainwater) before 1952 has tritium concentrations less than 5 tritium units (TU) while present day rainfall near LINL has 200 to $1000 \mathrm{TU}$ (Stone et al., 1982). Laboratory operations since the 1950's have elevated the tritium concentration in rainfall at LLNL by roughly an order a magnitude above that typically found elsewhere in Northern California (Stone et al., 1982). A tritium unit (TU) is a concentration of one atom of tritium for each $10^{18}$ total hydrogen atoms. One TU produces approximately $3.2 \mathrm{pci} / \mathrm{liter}$ of 
beta radiation which is the background activity of tritium in unenriched waters.

A 3 inch $(7.5 \mathrm{~cm})$ section of core recovered from each standard penetration test at $L R-1-R, L R-2-R$, and LR-4-P was reserved for tritium analysis. Additional samples were taken during the drilling of MW-119. Each sample was sealed in a glass jar with watertight tape, labeled with the date, borehole name, and depth of sample. It was then stored in a freezer that evening to preserve the water (tritium) until analyzed. Approximately 2 ounces $(250 \mathrm{gm})$ from the center of the frozen sample were removed and placed in a vacuum extraction system. The sample was then held under a vacuum for one day at room temperature followed by one day at $212^{\circ}$ to $257^{\circ} \mathrm{F}\left(100^{\circ}\right.$ to $\left.125^{\circ} \mathrm{C}\right)$. The water removed was analyzed by liquid scintillation counting (ISC). The LSC counters used for this study were dedicated to low level environmental determinations and calibrated with respect to blanks and standards in accordance with Environmental Protection Agency and Department of Energy specifications. The activity reported was the average value found over four 50 minute counting periods plus or minus two standard deviations. The percent moisture was determined for each soil sample analyzed for tritium by the following equation: 


$$
M=W_{W} / W_{t} \times 100 \%
$$

where:

$$
\begin{aligned}
& M=\text { percent moisture }() \\
& W_{W}=\text { weight of the water in sample (M) } \\
& W_{t}=\text { total sample weight }(M)
\end{aligned}
$$

$W_{W}$ was obtained by the difference in weight of the sample prior to and after moisture extraction. 


\section{RESULTS AND INTERPRETATION}

\section{Rainfall}

The total precipitation at ILNL during the 1985-86 water year was 16.8 inches $(43 \mathrm{~cm})$. There were eight storm intervals in that water year where the total rainfall was over 0.4 inches/week ( $1 \mathrm{~cm} /$ week) (fig. 10 and Table 1). Between each of these intervals there was at least one week of no significant precipitation, i.e., precipitation was less than 0.1 inches $(0.25 \mathrm{~cm})$. Only minor precipitation fell after March of that water year. The 1985-86 water year was slightly wetter than normal due to the contribution of two intense late winter storms (February 11-19, and March 7-15). During the study period, a maximum precipitation rate of 2.25 inches/day $(5.7 \mathrm{~cm} /$ day) occurred at the end of the February 11-19 storm. By way of comparison, the rate of precipitation for a 25 year storm is 2.5 inches/day (6.3 cm/day) (Littlefield, 1985).

\section{Runoff}

Three drainage channels deliver runoff into the drainage retention basin (fig. 11). The smallest channel lies northeast of the basin and drains approximately 8 acres north of the East Traffic Circle, 




(Kop/sausu!) (1) 
Table 1. Precipitation and estimated runoff in the watershed of the drainage retention basin during the 1985-86 water year. Note that the off-site runoff flowed into the basin following periods of high intensity rainfalls as indicated with a star $(*)$ below.



(1) Includes rainfall inside the basin 




Figure 11. Surface drainage patterns near the drainage retention basin and the southeast portion of LLNL 
located 400 feet $(122 \mathrm{~m})$ east of the basin. Under high flow conditions, off-site runoff from the east of LLNL combines with runoff from the southeastern portion of LLNL and enters the basin at its southeast corner. Runoff from the area south of the drainage retention basin empties into the basin at its southern edge. The southern channel has the quickest response to rainfall while the southeast channel has a delayed, but often greater response. Because the northeast channel drains a relatively small area it carries only low flows. The extent of the drainage retention basin watershed is outlined on Figure 12.

During the study period, off-site runoff bypassed the basin except during the February 11-19 and March 7-15 storms. During these two storms the channel along the east perimeter of IINL backed up at the east entrance of LINL so that much of the flow was diverted to the basin. No off-site runoff was observed to flow into the drainage basin under dry initial field conditions when 2.4 inches $(6.1 \mathrm{~cm})$ of precipitation occurred in a 24 hour period in January 1987. Minor discharges of irrigation water into the basin is common year round along each drainage channel especially via the southeast channel. A significant 




Figure 12. Watershed of the drainage retention basin (Thorpe et al., 1990). 
amount of runoff occurs semiannually when LLNL flushes its water supply lines.

Estimations of the surface runoff in the 1000 acre watershed of the drainage retention basin can be made by using the following equation:

$$
R O=P \times C \times W
$$

where;

$$
\begin{array}{ll}
\text { RO }=\text { surface runoff } & \left(\mathrm{L}^{3}\right) \\
\mathrm{P}=\text { rainfall } & (\mathrm{L}) \\
\mathrm{C}=\text { runoff coefficient } & (\mathrm{)} \\
\mathrm{W}=\text { watershed area } & \left(\mathrm{L}^{2}\right)
\end{array}
$$

The runoff coefficients used by LLNL's civil engineers for a 25 year storm are 1.0 for the 4 acres inside the basin, 0.5 for the 120 acres on site, and 0.3 for the 880 acres off site (Littlefield, 1985). These runoff coefficients are estimates based upon the slope of the terrain and type of ground cover encountered in each area. The on-site coefficient is greater than than the off-site coefficient due to the developed nature of the LLNL site. The equation above is a generalized relationship which assumes saturated soil conditions 
and does not consider such factors as the intensity of the precipitation and losses from stream flow percolation.

Observations of rainfall events at LLNL show that if there is 0.1 inch $(0.25 \mathrm{~cm})$ of rain within a 24 hour period, then approximately 0.05 acre-feet of runoff flows into the basin. This indicates that significant portions of the ground surface become saturated at this point. It also suggests that the equation may be modified to include unsaturated on-site initial field conditions by subtracting 0.1 inch $(0.25 \mathrm{~cm})$ from the total precipitation of each storm. Table 1 shows the estimated on-site runoff for the eight significant storms during the study period.

\section{Pond Size}

The pond within the 4 acre drainage retention basin has a maximum capacity of 28 acre-feet and generally contains some water throughout the year due to irrigation runoff. During the winter the volume of the pond can fluctuate rapialy due to the inflow of storm runoff. Figure 13 shows the depth of ponding during the 1985-86 water year. Figure 14 displays the relationship between pond depth and pond volume. In figure 14, the constant slope above a pond depth of 4.5 feet $(1.4 \mathrm{~m})$ 




(łazj) uldap puod






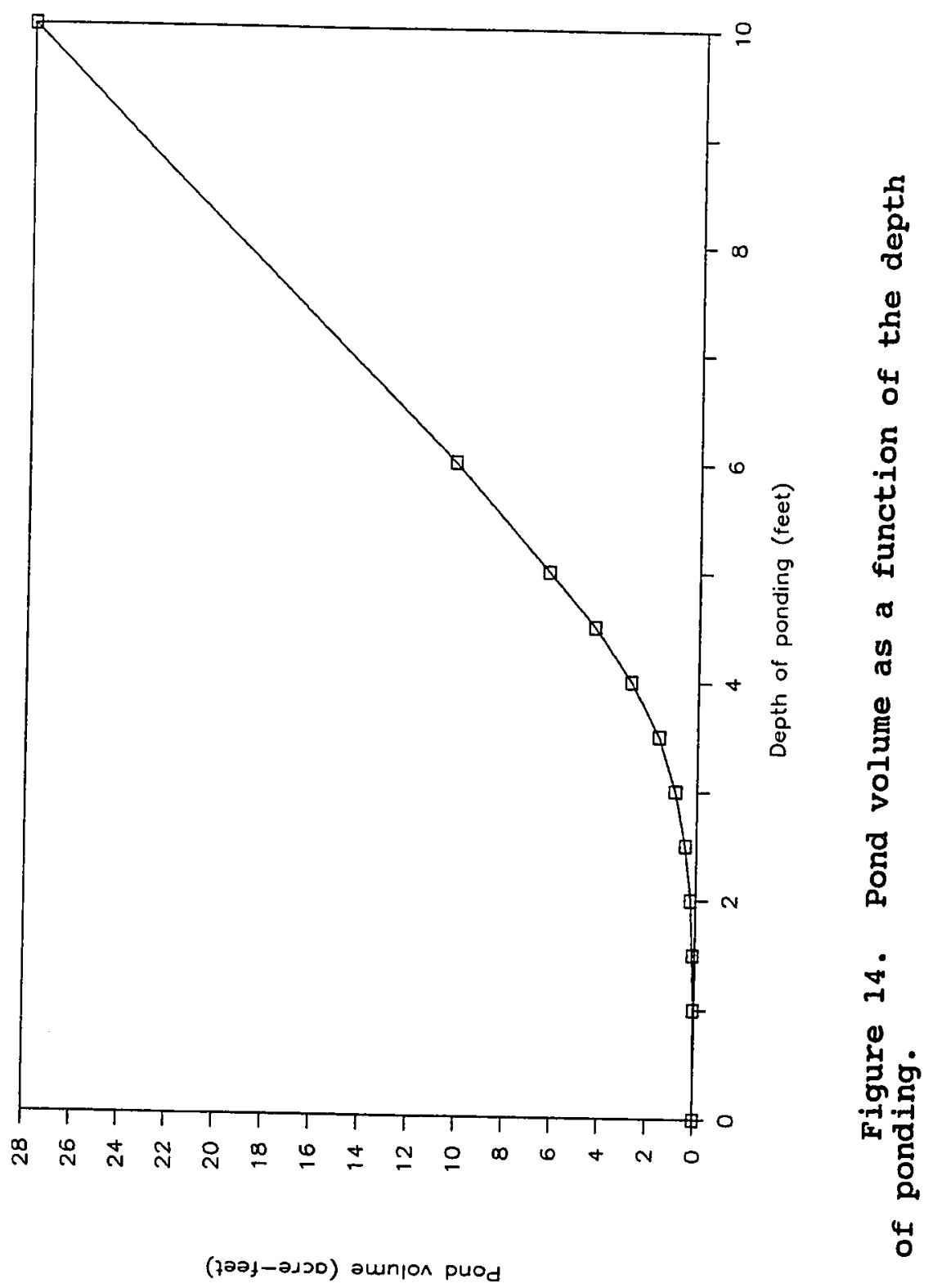


reflects the increasing depth of ponding once the basin floor has been inundated.

During the study period outflow occurred only

twice: on October 31, 1985 (when the basin was pumped

dry) and on February 19-20, 1986 (when the basin

overflowed through its overflow spillway). Large

changes in the size of the pond have been observed. For example, between February 18 and 19, 1986 the pond level rose from 6.2 to 10 feet $(1.9$ to $3 \mathrm{~m})$ and then dropped from 10 to 7.4 feet $(3.0$ to $2.3 \mathrm{~m})$ between February 20 and 21 .

The 2.6 foot $(0.8 \mathrm{~m})$ arop in water level after the end of the storm indicates an infiltration rate of 2.6 feet $(0.8 \mathrm{~m})$ per day. If this rate is extrapolated for the period when the pond was overflowing, then the total percolation for those two days is 20.8 acre-feet. The decrease in pond volume which occurred after each storm is found in Table 2. The total volume of water lost from the pond during the 1985-86 water year is at least 76.8 acre-feet.

\section{Geologic Logs and Cross-sections}

Appendix A contains the logs of borings drilled by this investigation in the drainage retention basin. The locations of these and earlier borings are shown on 
Table 2. Rainfall and the volume of water lost from the drainage retention basin after each storm. Note that the infiltration volume should be considered a minimum since minor inflows between storms were not considered.

\begin{tabular}{|c|c|c|}
\hline $\begin{array}{l}\text { Significant } \\
\text { storms }\end{array}$ & $\begin{array}{l}\text { | Total rain } \\
\text { | (inches) }\end{array}$ & $\begin{array}{l}\text { Infiltration } \\
\text { |(acre-feet) }\end{array}$ \\
\hline $20-0 c t-85$ & -1 & $11-$ \\
\hline $21-$ Oct- 85 & 0.71 & 2.8 \\
\hline $\begin{array}{l}09-N o v-85 \\
10-N o v-85\end{array}$ & -1 & i \\
\hline $\begin{array}{l}10 \text {-Nov- } 85 \\
23 \text {-Nov- } 85\end{array}$ & 0.82 & 3.4 \\
\hline $\begin{array}{l}23 \text {-Nov- } 85 \\
02-\text { Dec- } 85\end{array}$ & 2.34 & 5.0 \\
\hline $\begin{array}{l}29-\operatorname{Dec}-85 \\
04-J a n-86\end{array}$ & 0.83 & 2.5 \\
\hline $\begin{array}{l}10-\mathrm{Jan}-86 \\
17-\mathrm{Jan}-86\end{array}$ & 0.42 & 0.6 \\
\hline $\begin{array}{l}28-J a n-86 \\
04-F e b-86\end{array}$ & 1.76 & 3.2 \\
\hline $\begin{array}{l}11-\text { Feb- } 86 \\
19-\text { Feb- } 86\end{array}$ & 4.89 & 39.7 \\
\hline $\begin{array}{l}07-M a r-86 \\
15-M a r-86\end{array}$ & 3.65 & 19.6 \\
\hline Total & 15.42 & 76.8 \\
\hline
\end{tabular}


Figure 15. The location of boring D-4B is in question because its coordinates indicate that it lies only 9 feet $(2.7 \mathrm{~m})$ from $L R-2-R$ but its elevation is off by 1.7 feet $(0.5 \mathrm{~m})$. Figures 16,17 , and 18 show the geologic cross-sections of $A-A^{\prime}, B-B^{\prime}$, and $C-C^{\prime}$ on Figure 15. To reduce the detailed geologic data from the borings into an appropriate form for evaluating the ground water flow patterns, the sediments encountered in each boring are classified according to their estimated permeability relative to one another. Correlations are made between sediments with the same relative permeability and evaluated with respect to the depositional gradient and environment (Dresen and Nichols, 1986). Facies changes within the correlations are indicated by the variation in soil symbols seen on the cross-sections. Cross-section $A_{-A}$ (fig. 16) is 600 feet $(180 \mathrm{~m})$ long and oriented $\mathrm{N} 35^{\circ} \mathrm{W}-\mathrm{S} 35^{\circ} \mathrm{E}$ except between $\mathrm{LR}-1-\mathrm{R}$ and $\mathrm{D}-3$ where the section trends $\mathrm{N} 5^{\circ} \mathrm{W}-\mathrm{S} 5^{\circ} \mathrm{E}$. This geologic section shows the geology near the resistance cells and is subparallel to the depositional gradient. Near and northwest of $L R-4-P$ a few inches of silty clay has been recently deposited by the intermittent pond. Between the approximate elevations of 595 and 605 feet (181 and $184 \mathrm{~m}$ ) above sea level a 7 to 10 foot $(2.1$ to 3 m) thick, moderately permeable gravelly layer appears to 









Figure 16. Cross-section $A-A^{\prime}$. 



Figure 17. Cross-section B-B'. 


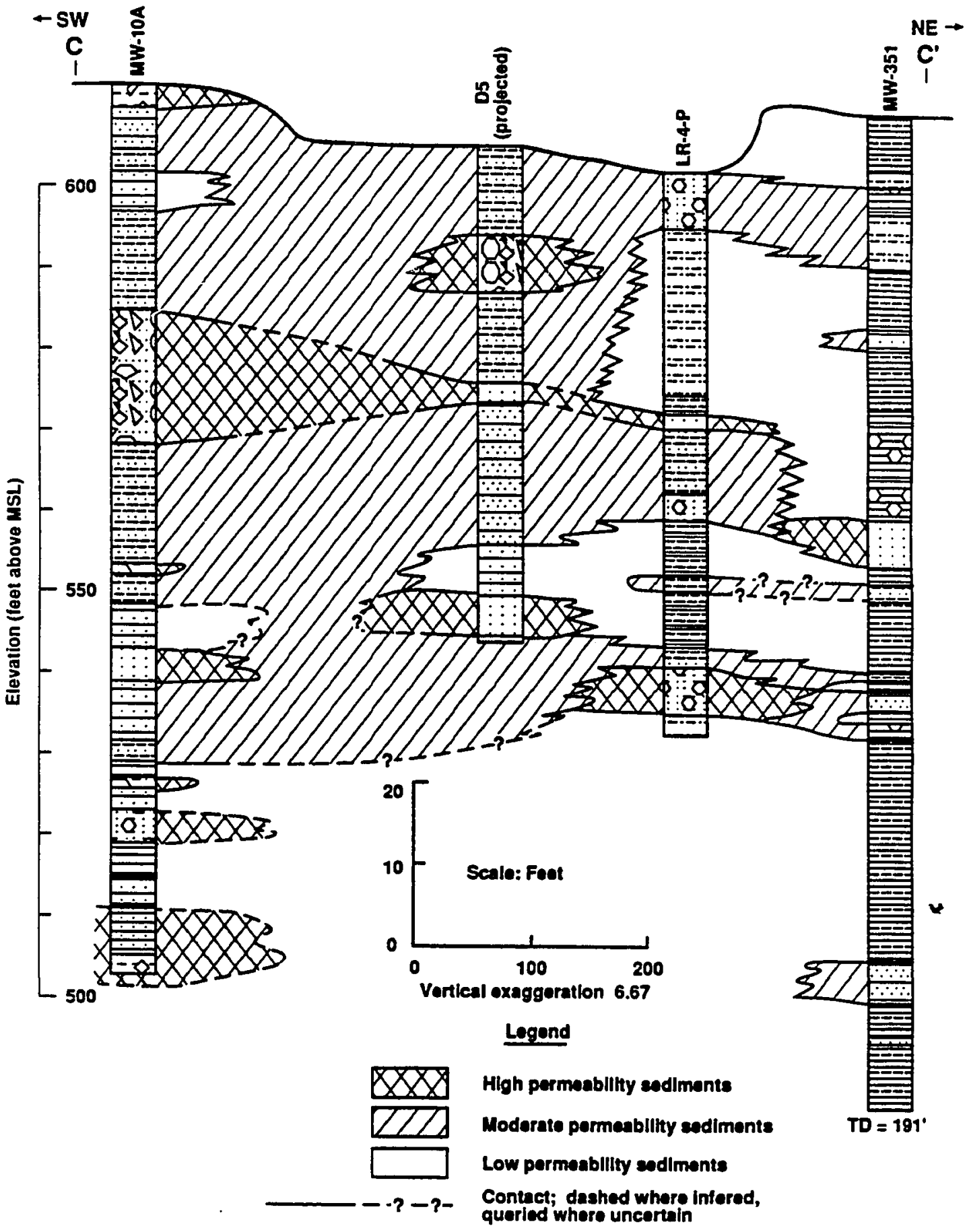

Figure 18. Cross-section C-C'. 
immediately underlie most of the basin floor. silty sediments with a low permeability dominate most of the vadose zone below this gravelly layer between $L R-4-P$ and LR-1-R. A highly permeable sand lens of limited extent is encountered near LR-2-R between the approximate elevations of 580 and 587 feet (177 and $179 \mathrm{~m}$ ) above sea level. A 2 to 8 foot $(0.6$ to $2.4 \mathrm{~m})$ thick, fairly continuous, and highly permeable sandy unit is found near the elevation of 573 feet $(175 \mathrm{~m})$ above sea level between $L R-1-R$ and $L R-4-P$. Sandy silt and silty sand deposits are interlensed with finer grained clayey and silty deposits between the approximate elevations of 558 and 565 feet $(170$ and $172 \mathrm{~m})$ above sea level. Below the September 1985 water table at LR-4-P, the first water-bearing zone is a 6 foot $(2 \mathrm{~m})$ thick, sandy gravel and a 2 foot $(0.6 \mathrm{~m})$ thick, silty sand. Several of the correlations appear to dip slightly towards the northwest which is consistent with the depositional gradient. The sediments between $L R-I-R$ and $D-3$ do not correlate as well as in the rest of the section. This may reflect the heterogeneity of alluvium near the basin, the section's deviation from the depositional gradient, and/or possibly different logging criteria used while logging the two borings. 
Cross-section B-B' (fig. 17) trends nearly east-west for 1000 feet $(305 \mathrm{~m})$ from $T B-25$ through the southern margin of the drainage retention basin to MW-10A. The geologic section is oriented oblique to the depositional gradient. Borings $D-5$ and $L R-1-R$ are projected 100 and 40 feet $(30$ and $12 \mathrm{~m})$, respectively, south into the line of section. A slight bend in the section occurs at $\mathrm{D}-3$. Coarse grained channel deposits and lateral facies changes are common in cross-section B-B'. The section $B^{\prime} B^{\prime}$, like section $A-A^{\prime}$, shows a continuous moderately permeable, gravel layer immediately underlying the basin and a highly to moderately permeable layer near the elevation of 573 feet $(175 \mathrm{~m})$ above sea level. A thick silty lens near MW-119 and $I R-1-R$ appears to pinch out before $D-5$ and D-3 so that more than 35 feet $(11 \mathrm{~m})$ of moderately and highly permeable sediments underlie the eastern and western portions of the basin. silty deposits appear to grade westward into a silty sand between the elevations of 570 and 550 feet ( 174 and $168 \mathrm{~m}$ ) above sea level. Below 550 feet $(168 \mathrm{~m})$ above sea level there is not enough data to confidently correlate the thinly interbedded layers.

Section C-C' (fig. 18) is 600 feet (183 m) long, normal to the depositional gradient and oriented 
$\mathrm{N} 45^{\circ} \mathrm{E}-\mathrm{S} 45^{\circ} \mathrm{W}$ through the western portion of the basin. D-5 is projected 45 feet $(13.5 \mathrm{~m})$ northwest into the line of section. This section shows that the gravelly layers, immediately underlying the basin and near an elevation of $573(175 \mathrm{~m})$ above sea level, grade finer towards the northeast between LR-4-P and MW-351. The sandy layers between elevations 550 and 535 feet (168 and $163 \mathrm{~m}$ ) above sea level, including the uppermost water-bearing zone, appear to be continuous across the cross-section. The screened interval in MW-351 is separated from the uppermost water-bearing zones by a thick sequence of clayey sediments. The Lower Livermore Formation is encountered below an elevation of 440 feet $(135 \mathrm{~m})$ above sea level at MW-351.

The silty soils below a depth of 7 feet $(2 \mathrm{~m})$ under the basin floor were found to be quite moist near the end of the dry season when the LR series boreholes were drilled. The sparsity of vegetation on the basin floor probably helped to minimize the water loss from the vadose zone due to evapotranspiration. In contrast the sediments at MW-10A, MW-119, and MW-351 were dry for the uppermost 20 feet $(6 \mathrm{~m})$ and damp in the rest of the vadose zone. Some moist soil was encountered in the vadose zone beyond the eastern perimeter of the basin while drilling MW-142, TB-25, CF-3, and CF-4 (Carpenter, 
1984). This may have been caused by infiltration near the vicinity of the East Traffic circle.

\section{Ground Water Levels}

Appendix B presents the well completion data and the measured hydraulic conductivity for monitoring wells within a $0.5 \mathrm{mile}(0.8 \mathrm{~km})$ radius from the drainage retention basin. Appendix c contains hydrographs of monitor wells at ILNL during the 1985-86 water year and is the basis for much of the following presentation. Continuous water level data from MW-119 show short term fluctuations due to changes in the barometric pressure. Commonly the fluctuations have a periodicity close to 24 hours and an amplitude of 0.04 feet $(1.2 \mathrm{~cm})$. Larger water level changes of up to 0.2 feet $(6 \mathrm{~cm})$ have a period of 3 to 6 days and follow the passing of a storm front. Short term water level fluctuations may be separated by several days where there is no measurable change. These temporary fluctuations make it difficult to accurately determine the exact temporal and spatial distribution of ground water recharge where the depth to water in a monitor well was measured less frequently than once a week.

The hydrographs of the monitor wells nearest the basin (MW-119 and $L R-4-P$ ) show the strongest response to 
ground water recharge (fig. 19). Even though they are screened in different water-bearing zones, the water levels in monitor well MW-119 and piezometer LR-4-P are observed to rise and fall in tanden over a range of more than 25 feet $(7.6 \mathrm{~m})$. The water table under the basin usually starts to rise 3 days after the onset of a storm. LR-4-P shows a somewhat stronger response than MW-119 to the first two storms in the 1985-86 water year. During the remainder of the study period, the water level in MW-119 is within 1 foot $(0.3 \mathrm{~m})$ of that at IR-4-P. Both hydrographs show a response to each of the eight significant storms during the study period. A maximum water level in $M W-119$ and $L R-4-P$ is seen to occur 7 to 15 days after the beginning of seven of the storms. The January 14-17 storm did not cause the water table to rise but did deflect the decay after the fourth peak. The similarity of water level response in MW-119 and IR-4-P indicates the presence of a hydraulic connection between the first two water-bearing zones near the drainage retention basin.

The hydrograph of $M W-10 A$ shows 5 distinct peaks and water level fluctuations over a 13 foot $(3.9 \mathrm{~m})$ range during the study period (fig. 19). The maximum water levels occur two to three weeks after the beginning of a significant storm. Ground water recharge 




นо!łอләן Jafom punoso 
from the first, second, and fifth storms does not appear to significantly impact the water levels in wells over 115 feet $(35 \mathrm{~m})$ away from the basin.

The last peak in the MW-10A hydrograph is higher than its preceding peak, but in the MW-119 and LR-4-P hydrographs the preceding peak is higher than the last peak. This is due to the fact that the water level in MW-10A dropped to a lesser extent than in MW-119 and LR-4-P before it was affected by recharge from the March 7-15 storm.

Water levels at MW-10A have been periodically recorded since it was installed in 1980 (fig. 20). There appears to be a rough linear correlation between the water level fluctuation in $M W-10 \mathrm{~A}$ and the amount of precipitation during a water year (fig. 21). The water level fluctuations for rain years 1980-81 and 1984-85 are probably greater than shown on Figure 20 since MW-10A was sounded only once a month during those years. No water level data was available for the 1983-84 water year.

In general, the water levels in monitor wells further away from the basin show a delayed, smaller, and more gradual response to ground water recharge from the drainage basin than wells close to the basin (fig. 22). If it is assumed that the water table elevation under 










영 吕 겅 通完 Q 궁


东 绐 क्ष ह5 (1) उ उद्व 茴出 0 ᄃ $030 n$ 雨告舟 क 90

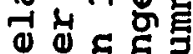



过要造

830


N ⿷匚⿱⿰㇒一大







is $x+$



ชᄈ 동











the perimeter of the basin is similar to that at LR-4-P and $M W-119$, then when the highest water levels are observed at MW-119 and LR-4-P the gradient of the water table between the pond perimeter and MW-1OA can be as much as 15.5 feet $(4.7 \mathrm{~m})$ over a distance of 115 feet $(35 \mathrm{~m})$ or 0.13 feet/foot. Shallower gradients are observed at greater distances from the basin and when the water table mound under the basin is less developed. The changes in the water levels for wells between a distance of 100 and 2200 feet $(30$ and $670 \mathrm{~m}$ ) from the basin during and after the February 11-19 and March 7-15 storms are shown on Figure 23. Monitor wells MW-114 and MW-257 may have received some recharge from nearby drainage ditches. This is suggested by a water level rise which appears slightly higher and sooner than that seen at MW-101, which is a comparable distance away from the basin (fig. 23). MW-258 appears to have a delayed response to the recharge from the drainage basin. In this case the delayed response may be due to the fact that MW-258 is screened in a water-bearing zone which is deeper than most of the other monitoring wells and has a lower transmissivity. MW-204 and MW-113 also appear to be somewhat isolated to the recharge. This may be due to a lateral discontinuity in the upper water-bearing zones southeast of the basin. 





The net water level rise as seen in most of the monitor wells at LLNL between February 15 and April 15, 1986, is contoured on Figure 24. Hydrographs of wells MW-116, TB-11, and MW-5 show a water level rise of over one foot $(0.3 \mathrm{~m})$ within a month following the February 11-19 storm due to ground water recharge from the Arroyo Seco and the Arroyo Las Positas. The water levels in MW-141, MW-7 and probably $M W-4$ appear to have risen due to recharge from both the drainage retention basin and the Arroyo Las Positas. Water levels in MW-12, MW-148, MW-147, MW-146, and perhaps several other wells in the southwest portion of LINL also appear to be influenced by recharge from both the drainage basin and the Arroyo seco. The volume of groundwater and soil in the water table mound that developed between February 15 and April 15, 1986, due to the recharge from the drainage basin is approximately 750 acre-feet. The one foot contour of the water level rise due to recharge from the basin is roughly outlined by MW-7, MW-141, MW-148, MW-12, MW-206 and $\mathrm{MW}-17$ on Figure 24.

The net water level rise seen in most wells at LLNL over the 1985-86 water year is between 1 and 2 feet $(0.3$ and $0.6 \mathrm{~m})$. Generally the net water level rise is greater southeast of the drainage basin. The wells in the eastern part of LLNL (see hydrographs of MW-17, 





$M W-19, M W-106, M W-113, M W-117$, and $M W-206)$ have a gradual, year-round water level rise, while the water level in the western wells commonly start to decline during the late summer (see hydrographs of MW-2, MW-4, MW-12, MW-101, MW-105, MW-141, and MW-146). This pattern of water level change has attenuated the ground water depression near $M W-117$ and $M W-19$ identified by stone et al. (1982).

\section{Electrical Resistance in Soils}

The resistance data from september 26, 1985 to October 1, 1986 is presented in Appendix D. Resistance data from February 10 to March 3, 1986, is presented and discussed in detail in Appendix E. Usually the resistance measured at a particular cell is continuous and changes at the same time as its pair, even though their absolute values may be quite different. Some of the resistance cells above a depth of 6 feet $(1.8 \mathrm{~m})$ have a slight daily fluctuation, probably in response to the temperature changes near the ground surface. A drop in the resistance values at a depth of 2 feet $(0.6 \mathrm{~m})$ at $L R-2-R$ is seen after each significant storm (fig. 25). A comparison between the resistance data and the soil type during both the wet and dry season is presented on Table 3. Most of the resistance cells 









Table 3. Soil resistance data for the soil types encountered. Note the wide range of resistance values and the variability in the ratio of the winter over summer readings for each soil type.




Table 3 (continued).

\begin{tabular}{|c|c|c|c|c|c|}
\hline Soil type & $\begin{array}{l}\text { Resistance } \\
\text { cell }\end{array}$ & & $21-$ Sept- 86 & $24-f e b-86$ & $\begin{array}{l}\text { Ratio } \\
\text { Feb/Sept }\end{array}$ \\
\hline \multirow[t]{4}{*}{$\begin{array}{l}\text { Silty } \\
\text { sand }\end{array}$} & $L R I R-47$ & $\begin{array}{l}\mathrm{A} \\
\mathrm{B}\end{array}$ & $\begin{array}{l}2674 \\
2939\end{array}$ & $\begin{array}{r}88 \\
1483\end{array}$ & $\begin{array}{l}0.03 \\
0.50\end{array}$ \\
\hline & LR2R-39.5 & $\begin{array}{l}\text { A } \\
\text { B }\end{array}$ & $\begin{array}{r}243 \\
1413\end{array}$ & $\begin{array}{l}265 \\
532\end{array}$ & $\begin{array}{l}1.09 \\
0.38\end{array}$ \\
\hline & LR2R -48.5 & $\begin{array}{l}\text { A } \\
\text { B }\end{array}$ & $\begin{array}{r}635 \\
1185\end{array}$ & $\begin{array}{l}167 \\
155\end{array}$ & $\begin{array}{l}0.26 \\
0.13\end{array}$ \\
\hline & LR3R -40.5 & $\begin{array}{l}\text { A } \\
\text { B }\end{array}$ & $\begin{array}{l}397 \\
927\end{array}$ & $\begin{array}{l}160 \\
213\end{array}$ & $\begin{array}{l}0.40 \\
0.23\end{array}$ \\
\hline Average of & Feb/Sept & ratio & 1302 & 383 & 0.29 \\
\hline \multirow{7}{*}{$\begin{array}{l}\text { Gravelly } \\
\text { or } \\
\text { sandy } \\
\text { silt }\end{array}$} & LR1R-13.5 & $\begin{array}{l}\text { A } \\
\text { B }\end{array}$ & $\begin{array}{l}392 \\
520\end{array}$ & $\begin{array}{l}170 \\
107\end{array}$ & $\begin{array}{l}0.43 \\
0.21\end{array}$ \\
\hline & LR1R - 22 & $\begin{array}{l}\text { A } \\
\text { B }\end{array}$ & $\begin{array}{l}230 \\
564\end{array}$ & $\begin{array}{r}79 \\
108\end{array}$ & $\begin{array}{l}0.34 \\
0.19\end{array}$ \\
\hline & LR1R - 39 & $\begin{array}{l}A \\
B\end{array}$ & $\begin{array}{l}458 \\
310\end{array}$ & $\begin{array}{l}95 \\
69\end{array}$ & $\begin{array}{l}0.21 \\
0.22\end{array}$ \\
\hline & LR2R-13.5 & $\begin{array}{l}\mathrm{A} \\
\mathrm{B}\end{array}$ & $\begin{array}{l}1935 \\
1607\end{array}$ & $\begin{array}{l}437 \\
459\end{array}$ & $\begin{array}{l}0.23 \\
0.29\end{array}$ \\
\hline & LR3R-9.5 & $\begin{array}{l}\text { A } \\
\text { B }\end{array}$ & $\begin{array}{l}189 \\
160\end{array}$ & $\begin{array}{l}233 \\
169\end{array}$ & $\begin{array}{l}1.23 \\
1.06\end{array}$ \\
\hline & LR3R-15.5 & $\begin{array}{l}\text { A } \\
\text { B }\end{array}$ & $\begin{array}{l}301 \\
449\end{array}$ & $\begin{array}{l}209 \\
619\end{array}$ & $\begin{array}{l}0.69 \\
1.38\end{array}$ \\
\hline & LR3R-54 & $\begin{array}{l}\text { A } \\
\text { B }\end{array}$ & $\begin{array}{l}1196 \\
1331\end{array}$ & $\begin{array}{l}903 \\
934\end{array}$ & $\begin{array}{l}0.76 \\
0.70\end{array}$ \\
\hline Average of & Feb/Sept & ratio & 689 & 328 & 0.48 \\
\hline
\end{tabular}


Table 3 (continued).

\begin{tabular}{|c|c|c|c|c|c|}
\hline Soil type & $\begin{array}{l}\text { Resistance } \\
\text { cel1 }\end{array}$ & & 21-Sept-86 & $24-f e b-86$ & $\begin{array}{c}\text { Ratio } \\
\text { Feb/Sept }\end{array}$ \\
\hline \multirow{3}{*}{$\begin{array}{l}\text { Silt } \\
\text { or } \\
\text { clayey } \\
\text { silt }\end{array}$} & LR1R-8 & $\begin{array}{l}\text { A } \\
\text { B }\end{array}$ & $\begin{array}{l}152 \\
253\end{array}$ & $\begin{array}{r}64 \\
151\end{array}$ & $\begin{array}{l}0.42 \\
0.60\end{array}$ \\
\hline & LR2R-10.5 & $\begin{array}{l}\text { A } \\
\text { B }\end{array}$ & $\begin{array}{l}646 \\
401\end{array}$ & $\begin{array}{l}312 \\
165\end{array}$ & $\begin{array}{l}0.48 \\
0.41\end{array}$ \\
\hline & LR3R-19.5 & $\begin{array}{l}\text { A } \\
\text { B }\end{array}$ & $\begin{array}{l}271 \\
497\end{array}$ & $\begin{array}{l}311 \\
476\end{array}$ & $\begin{array}{l}1.15 \\
0.96\end{array}$ \\
\hline Average of & Feb/Sept r & atio & 370 & 247 & 0.67 \\
\hline
\end{tabular}


indicate a higher moisture content in the winter when the pond level and the infiltration rate is relatively high. The similarity between the summer and winter resistance readings in the top 20 feet $(6 \mathrm{~m})$ in $\mathrm{LR}-3-\mathrm{R}$ is probably a result of year-round ponding and infiltration nearby.

There is generally a correlation between the grain size distribution in a soil and the behavior of the resistance cells in response to transient ground water flow. The soil resistance is usually greater in coarser grained soils than in fine grained soils (Table 3). The resistance in coarse grained soils drops rapidly in response to increasing soil moisture and increases quickly during drying cycles (see resistance cells at the depths of 2 and 30.3 feet in $L R-1-R$, at 2 and 30.5 feet in $L R-2-R$, and at 28.5 feet in $L R-3-R)$. For example, a resistance drop of more than $50 \%$ of the initial value is noticed, in a two day period, following the February 11-19 storm in the sandy layer near a depth of 30 feet $(9 \mathrm{~m})$ below the basin floor at each boring (fig. 26)

Fine grained silty soils generally have a constant year-round resistance value somewhere below 600 ohms (see resistance cells at the depths of 8 and 13.5 feet in $L R-1-R$, at 10.5 and 13.5 feet in $L R-2-R$, and at 9.5, 




(sய40-O!!y) ә0บ015!sad 1!OS 
$15.5,19.5,40.5$, and 54 feet in LR-3-R). Soils ranging from silty sands to silty gravels display moderate changes in soil resistance or moisture content.

Other factors which have an influence on the resistance data include the antecedent moisture content and the depth of and horizontal distance to ponding in the basin. The largest drop in resistance is found at the uppermost cells in $L R-1-R$ and $L R-3-R$ after the first storm. Here very high resistance values are seen to decrease by roughly an order of magnitude. This drop reflects the contrast in moisture conditions between the desiccation of the surface soil during the dry season and the infiltration of a wetting front into the subsurface during a storm. An inverse relationship between the depth of ponding and the resistance is seen on Figure 27.

Not every cell responds to each storm. No significant resistance change is noticed below 13.5 feet $(4.1 \mathrm{~m})$ at $L R-1-R$ unless the boring is covered by the pond (fig. 27). A lack of a significant response is also seen at $L R-3-R$ throughout most of the study period in the soil near the depths of 5, 9, and 15 feet (1.5, 2.7 , and $4.5 \mathrm{~m}$ ). The latter cases, however, probably reflect a near constant moisture content due to poor 





drainage and year-round infiltration near the deepest part of the basin, where some ponding almost always exists.

A minimal response is seen in the sandy soil at a depth of 21 feet $(6.4 \mathrm{~m})$ in LR-2-R. This station shows a late and slight response to the February 11-19 storm (fig. 28). The delayed and minimal change of moisture content in the sandy soil is a result of different hydraulic responses as reflected in the difference in characteristic curves (i.e. the relationship between soil moisture and pore pressure and between hydraulic conductivity and pore pressure (fig. 7)) between the unsaturated sand and silt deposits. Here the sandy soil appears to be isolated from other coarse grained deposits (fig. 16). The capillary tension in the surrounding silty deposits would prevent ground water from entering the sand until a relatively high moisture content is achieved and the tension in the silt becomes small.

There are several instances where a wetting front appears to migrate downward. For example, the wetting front is seen to propagate to 28.5 feet $(8.7 \mathrm{~m})$ in 1.5 days at $L R-3-R$ (fig. 29 ) and to 30.5 feet $(9.1 \mathrm{~m}$ ) in 2 days at LR-2-R (fig. 30). 








әsuofs!saj U! dosp fuas jad 







In several cases a sharp decrease in the soil resistance appears to migrate upward. During the February 11-19 storm a delayed dramatic resistance drop is noticed in the cells at 30 feet $(9 \mathrm{~m})$ in $L R-1-R$ and LR-2-R two days after a similar drop in cells near depths of 40 and 50 feet ( 12 and $15 \mathrm{~m}$ ) (figs. 31 and 32). This pattern of resistance change may reflect a rising water table near the deeper resistance cells and/or a function of different characteristic curves of the unsaturated hydraulic parameters between different soil types.

Another anomalous wetting pattern is seen at a depth of 22 feet $(6.5 \mathrm{~m})$ in LR-1-R. This station often shows a slight drop in soil resistance two days sooner than the cells at a depth of 8 or 13.5 feet $(2.4$ or 4.1 m) (fig. 33). This relationship suggests that some ground water flows around and under the clayey silt and sandy silt at a depth of 6 to 14 feet near IR-I-R.

A summary of the distribution and movement of ground water after the onset of the February 11-19 storm is shown on Figure 34. The time given on Figure 34 is for the accumulation of enough water to start to cause a significant drop in the soil resistance (see Appendix E for a detailed interpretation of this resistance data). The shallowest resistance cells are the first to respond 




(su40-이거) 25ujs!sad 1!OS 



(sw40-이가) asudis!sa, l!OS 










to the storm. The resistance cells at a depth of 19.5 feet $(5.9 \mathrm{~m})$ in $L R-3-R$ show a slight drop on February 14 when the water levels in $M W-119$ and $L R-4-P$ started to rise. In $L R-1-R$ and $L R-2-R$, however, the wetting front does not arrive at a depth of 20 feet $(6 \mathrm{~m})$ until February 15 or 16. The resistance cells at a depth of approximately 40 and 50 feet $(12$ and $15 \mathrm{~m})$ in $L R-1-R$ and $L R-2-R$ respond to either a wetting front or a rising water table on February 15 and 16. Several days later, on February 18 through 22, the resistance cells near a depth of 30 feet and those at a depth of 40.5 and 54 feet in $L R-3-R$ show the onset of a larger rate of increasing moisture (fig. 26).

\section{Infiltration Rates}

Graphs of the infiltrometer data from ten trials are presented in Appendix $F$. The infiltration rates varied from 0.004 foot/day $(0.001 \mathrm{~m} /$ day $)$ to approximately 1 foot/day $(0.3 \mathrm{~m} /$ day $)$ in the upper reaches of the basin. A maximum rate of 8.8 feet/day $(2.7 \mathrm{~m} /$ day $)$ is observed in the eastern portion of the basin soon after the start of a test. Generally the infiltration rate peaks soon after the beginning of the test and then gradually approaches a steady state value (fig. 35). Standard deviations of the last four data 







points during the infiltration tests varied between $16 \%$ and $71 \%$ of the final average.

In three tests, infiltration rates were calculated using both the volume loss and the falling head approaches. Similar results were obtain by either method in these three tests. At three locations, two consecutive tests were conducted without moving the double-ring infiltrometer. In two of these tests, the latter tests displayed much lower infiltration rates. Some erosion when the infitration rings were filled may have increased the infiltration rate during the latter test where the latter test had a greater infiltration rate.

The distribution of the measured infiltration rates in the drainage retention basin is shown on Figure 36. In the basin, the lowest rates are found where water is commonly ponded throughout the year (near LR-4-P and in the northeast corner of the basin). The infiltration rate at these locations is slower due to the presence of a few inches of silty clay.

\section{Saturated Hydraulic Conductivity Rates}

The data from the three triaxial permeameter tests is graphed in Appendix $G$. The results of these tests are summarized in Table 4. The conductivity values vary 
96




\&.

의

$\rightarrow \stackrel{0}{J}$



品

(1).-7

$+4$

究 05

5 咅

$\therefore \pi$

용

क्ष.

㝳武。

그음

出的

$\stackrel{\leftrightarrow}{\mathrm{E}}$

可

क

넌

ᄀ

का 0

品

45

嵌

प्र

总㟔药

\pm 我

4

.

44 40 过

요 0

为山

40

0 o

0

$m$ 걱

(1) क

蛋苾 的

$\rightarrow \circlearrowleft$ 可



$4 \pi$

\& 
Table 4. Saturated hydraulic conductivities from core samples below the basin. See Appendix G for more data.

\begin{tabular}{lllll}
$\begin{array}{l}\text { Sample } \\
\text { name }\end{array}$ & $\begin{array}{l}\text { Soil } \\
\text { type }\end{array}$ & $\begin{array}{l}\text { Head } \\
\text { (PSI) }\end{array}$ & $\begin{array}{l}\text { Saturated } \\
\text { conductivity } \\
\text { (cm/day) }\end{array}$ \\
\hline $\begin{array}{l}\text { Standard } \\
\text { deviation }\end{array}$ \\
LR4P-55 & Sandy silt & 43.7 & $4.8 \times 10-4$ & 158 \\
LR1R-40 & Sandy silt & 31.9 & $1.5 \times 10-3$ & 468 \\
LR1R-40 & Sandy silt & 63.2 & $1.0 \times 10-3$ & 358 \\
LR2R-30 & Sand & 0.4 & & 680
\end{tabular}


between $1.6 \times 10^{-5}$ and 2.2 feet/day $\left(4.8 \times 10^{-6}\right.$ and 0.68 $\mathrm{m} /$ day) and are consistent with those reported in the literature (Freeze and Cherry, 1979).

The sensitivity of sandy deposits to the degree of saturation is suggested by the analysis of the core recovered at LR-2-R. A loss of almost $40 \%$ of the flow rate through the core was seen as untreated deionized water replaced the degased deionized water which originally saturated the sample (fig. 37). Gas in the untreated water apparently came out of solution to form bubbles which blocked the pores and thereby reduced the hydraulic conductivity.

\section{Tritium Concentrations in soil}

The results of tritium and percent moisture in soil samples from $L R-1-R$, $L R-2-R, L R-4-P$, and $M W-119$ are presented in Table 5. The distribution of tritium is found to be rather uniform in boring LR-4-P (fig. 38). At MW-119, however, water with elevated tritium is found to a depth of 40 feet $(12 \mathrm{~m})$ and in the first waterbearing zone at 76 feet $(23 \mathrm{~m}$ ) (fig. 38). Deeper waterbearing zones at MW-119 were not sampled. This data shows the significant influence of ponding on ground water flow in the vadose zone. At areas where water is not ponded (e.g., MW-119) the vertical infiltration rate 





Table 5. Tritium (tritium units, TU) in soil near the drainage retention basin. Samples from water-bearing zones are indicated with a star $(*)$. The counting uncertainty is plus or minus two standard deviations.

$\begin{array}{lcrcc}\begin{array}{l}\text { Borehole } \\ \text { name }\end{array} & \begin{array}{l}\text { Sample } \\ \text { depth } \\ \text { (feet) }\end{array} & \begin{array}{c}\text { Tritium } \\ \text { in soil } \\ \text { (TU) }\end{array} & \begin{array}{l}\text { Counting } \\ \text { error } \\ \text { (TU) }\end{array} & \begin{array}{l}\text { Moisture } \\ \text { content } \\ (8)\end{array} \\ \text { MW-119 } & 16.0 & 1377.1 & 48.6 & 3.6 \\ \text { MW-119 } & 20.0 & 1564.4 & 50.9 & 3.3 \\ \text { MW-119 } & 30.5 & 1131.3 & 46.5 & 4.1 \\ \text { MW-119 } & 36.0 & 949.5 & 44.6 & 4.7 \\ \text { MW-119 } & 42.0 & 346.5 & 38.4 & 11.1 \\ \text { MW-119 } & 46.0 & 367.2 & 38.1 & 10.4 \\ \text { MW-119 } & 51.0 & 227.7 & 36.8 & 16.2 \\ \text { MW-119 } & 57.0 & 95.8 & 35.3 & 36.9 \\ \text { MW-119 } & 60.0 & 417.8 & 38.7 & 9.3 \\ \text { MW-119 } & 67.0 & 243.7 & 36.7 & 15.1 \\ \text { MW-119 } & 71.0 & 305.0 & 36.9 & 12.1 \\ \text { MW-119* } & 76.0 & 1280.6 & 47.7 & 3.7 \\ \text { MW-119 } & 81.0 & 521.2 & 39.6 & 7.6 \\ \text { MW-119 } & 82.5 & 400.9 & 38.6 & 9.6 \\ \text { MW-119 } & 88.0 & 434.9 & 39.0 & 9.0 \\ & & & & \\ \text { LR-1-R } & 56.0 & 626.1 & 40.1 & 6.4 \\ & & & & \\ \text { LR-2-R } & 55.5 & 625.2 & 40.1 & 6.4 \\ \text { LR-4-P } & 10.0 & 589.6 & 39.4 & 6.7 \\ \text { LR-4-P } & 20.0 & 802.6 & 42.1 & 5.2 \\ \text { LR-4-P } & 30.0 & 829.8 & 42.5 & 5.1 \\ \text { LR-4-P } & 40.0 & 624.9 & 82.3 & 13.2 \\ \text { LR-4-P } & 50.0 & 605.0 & 39.7 & 6.6 \\ \text { LR-4-P } & 55.0 & 749.0 & 48.5 & 6.5 \\ \text { LR-4-P * } & 60.0 & 806.0 & 42.1 & 5.2 \\ & & & & \end{array}$






Figure 38. Profiles of the tritium concentration in soil. Note the breakthrough of recent tritium to a depth of 40 feet at MW-119, while the tritium distribution in $\mathrm{LR}-4-\mathrm{P}$ is near equilibrium. 
is less than 1 foot/year $(0.3 \mathrm{~m} /$ year). The tritium distribution at LR-4-P, however, indicates that very recent atmospheric water has traveled through the unsaturated zone and entered the saturated ground water system.

The tritium concentrations in soil from $L R-4-P$ is much less than that found in the soil from the upper vadose zone at $M W-119$. This may be due to infiltration of recent atmospheric water with relatively low tritium concentrations (as compared to that circa 1955-75) and/or the influx of off-site water, which is less affected by LLNL operations. The elevated tritium concentrations in the water-bearing zone at MW-119 indicates that either tritium has been released to ground water upgradient of the area or, more likely, young, tritium enhanced water has infiltrated from the basin and migrated laterally beyond the perimeter of the basin in the upper water-bearing zones. 


\section{DISCUSSION}

\section{Ponding in the Drainage Retention Basin}

Based on observations over the 1985-86 water year, the inflow of water to the basin from storms with a total precipitation of less than 2.5 inches (6.4 $\mathrm{cm}) /$ week is most likely confined to on-site runoff. For larger storms (i.e. February 11-19) the off-site runoff contribution to the pond can be more than three times greater than the on-site runoff. The correlation between the estimated on-site surface runoff and the volume of water which percolated from the pond is presented in Table 6 for the first six storms during the 1985-86 water year. On-site surface runoff is estimated by using a surface runoff coefficient of 0.5 and assuming soil saturation after 0.1 inches of precipitation. This relationship appears to be less accurate for the longer storm periods due to evapotranspiration during lapses in precipitation and insufficient pond volume and precipitation data.

The correlation between rainfall and the volume of water which percolates from the basin into the subsurface after each storm is presented on Figure 39. Calculations of the maximum pond volume and the pond volume loss may be somewhat less than expected since the 
Table 6. A comparison between loss of pond volume and calculated on-site runoff. Note that a ratio greater than 1 is observed for the last two storm periods when off-site runoff is known to have entered the basin.








Figure 39. Correlation between rainfall and basin percolation. 
maximum pond level may have occurred at a time when there were no observations. The sharp increase in percolation indicated by the last two data points on Figure 39 is due to inflow from off-site. Surface runoff can cause the pond to overflow when the intensity of the rainfall approaches that of a 25 year storm (e.g., February 18-19, 1986) for a prolonged period. In the future, outflow from lesser storms is to be expected due to the installation of an outflow pipe and the ongoing accumulation of silt on the basin floor. These two factors have also decreased the rate of pond volume loss.

The size of the pond appears to greatly affect the percolation rate (fig. 13). The highest rate of volume loss (12 acre-feet/day) from the pond is seen when the pond is near its capacity. The decay of the rate at which the pond level drops after each storm indicates that the percolation rate slows down as the pond size decreases. Summer pond volume loss by evaporation (up to 6 inches/month ( $15 \mathrm{~cm} /$ month) (CDWR, 1974)) approaches that of the percolation rate when the pond is near 2 feet $(0.6 \mathrm{~m})$ deep.

There are several factors that may explain why a decreasing pond level results in a lower percolation rate. The depth of ponding has a direct influence on 
the hydraulic pressure on the basin floor. According to Darcy's Law, the head differential has a linear relationship with the flow or infiltration rate. Secondly, the results from the double-ring infiltration tests show that the upper reaches of the pond have infiltration rates which are much greater than those found near either LR-4-P or the northeast corner of the basin. A lower pond level would cover a smaller proportion of the more permeable sediments and therefore have a lower average percolation rate. Lower pond levels also cause water to percolate through a limited area of the basin floor which would contribute to a smaller pond volume loss.

The ongoing deposition of silt and clay on the basin floor also has a direct effect on the percolation rate. At the northeast corner and the lowest portion of the basin, the surficial silt is locally over 4 inches $(10 \mathrm{~cm})$ deep. The measured deposition in these two low lying areas during the 1985-86 water year was approximately 1 inch $(2.5 \mathrm{~cm})$. As the silt accumulates, the percolation rate will decrease because the silt layer not only becomes thicker, but also spreads over an ever larger area. Thus the time necessary for a given amount of water to flow through this layer increases as time goes on. 


\section{Ground Water Flow in the Vadose zone}

There are several lines of evidence which indicate that ground water flow in the vadose zone at LLNL is highly variable and dependent upon the proximity of surface waters as well as the physical properties of the soil. Soil tritium profiles at LLNL in areas away from ponded water or drainage channels suggest that "rainfall infiltration apparently has not progressed more than approximately 40 feet $(12 \mathrm{~m}$ ) below the surface" (Stone et al., 1982). The tritium concentrations in soil samples from boreholes $I R-4-P$ and $M W-119$ indicate that the predominant flux of ground water flow in the unsaturated zone is oriented downward from locations where water is commonly ponded. The tritium concentration in soil analyzed from LR-4-P appears to be in equilibrium with recent atmospheric water in the vicinity of LLNL. At MW-119, however, the infiltration of recent water has not traveled further than a depth of 40 feet $(12 \mathrm{~m})$ (fig. 38). The effect of ponding is also seen in the resistance data at LR-1-R where many of the resistance cells show increased moisture only after the surface of the borehole is flooded (fig. 27).

Local infiltration from the unlined drainage channels is suggested by the water level data from 
MW-114 and MW-257. The water level in these wells appears to rise sooner and higher, in response to infiltration from the channels, than wells a similar distance from the basin but away from the drainage channels (fig. 23).

Ground water flow rates in the vadose zone near the drainage retention basin show considerable variability depending upon the hydrogeology and what assumptions are made. Maximum flow rates of at least 17 feet/day ( $5 \mathrm{~m} /$ day) are indicated for some areas under the basin by the fact that the water table, approximately 50 feet (16 $\mathrm{m}$ ) below the basin floor, started to rise within 3 days after a significant inflow of water into the basin. The fact that the water level in $M W-119$ and $L R-4-P$ rose steadily for 10 days at a rate of 2.7 feet/day $(0.8 \mathrm{~m} /$ day $)$ during and after the February 11-19 storm, indicates that the average ground water flow rate at this time in the vadose zone under the area of the basin must be as least as fast. Further quantification of ground water flow rates in the vadose zone requires the assessment of the change in percent water in the soils and the lateral migration of the water table mound which are not adequately defined in this study. The heterogeneity in the permeability of the alluvial deposits near the basin and transitory 
rates of percolation from the pond probably account for the wide range of flow rates observed in the vadose zone.

The tracing of the arrival of several wetting fronts through the network of resistance cells reveals a pattern of ground water movement in the vadose zone which is dependent on the distribution of permeable sediments and antecedent moisture conditions. The wetting fronts do not arrive at the resistance cells deeper than 30 feet until after the water table starts to rise. This suggests that ground water infiltration is less effective near the center of the basin where the resistance cells are located. Ground water infiltration appears to be less efficient through and below the silty deposits under the central portion of the basin, than in the predominantly highly and moderately permeable deposits below the eastern and western portions of the basin (fig. 17).

Wetting fronts commonly appear to migrate downward through the vadose zone after storm derived runoff raises the pond level inside the basin. The resistance data reveals a progression of increased moisture to depths of 30 feet after some storms (figs. 29 and 30). The dry antecedent conditions at LR-3-R, before the October 20-21, 1985 storm allows the observation of the 
progression of the wetting front to a depth of 28.5 feet $(8.7 \mathrm{~m})$ within 1.5 days after the start of the storm. This observation indicates a minimum wetting front velocity of 14 feet/day $(4.3 \mathrm{~m} /$ day $)$ on this occasion. A progression of large changes in the resistance data from $L R-3-R$ is not as well developed after the subsequent storms. This lack of a pronounced wetting front at LR-3-R after the later storms may to be due to poor drainage and near continuous infiltration from the pond over the course of the wet season.

In several cases a sharp increase in the moisture content at intermediate depths occurs after a similar change in moisture content at deeper depths. During the February 11-19 storm a delayed dramatic drop in soil resistance is noticed in the cells at a depth of 30 feet ( $9 \mathrm{~m}$ ) in $L R-1-R$ and $L R-2-R$ two days after a similar sharp drop in the cells near 40 and 50 feet (12 and 15 m) (figures 26 and 27). This may be attributed to a rising water table and/or the migration of ground water in only the lower portion of the coarse grained deposit immediately below the resistance cells near a depth of 30 feet $(9 \mathrm{~m})$. In the second scenario, groundwater would percolate into the coarse grained deposit from the eastern and/or western portions of the basin, where where more permeable sediments are found in the 
uppermost 30 feet, and flow along the base of the coarse grained deposit towards $L R-1-R$ and $L R-2-R$. It appears to take a few days for moisture to build up in the fine grained soil at $L R-I-R$ and $L R-2-R$ before water can flow into the underlying coarser grained deposit.

On February 13, 1986, an increased moisture content at a depth of 22 feet $(6.5 \mathrm{~m})$ in $L R-1-R$ is seen two days earlier than the other cells in this borehole except for the two uppermost stations (fig. 33). This may be due to a hydraulic connection to near saturated permeable sediments. Ground water may flow laterally towards $L R-1-R$ along the contacts between soils of contrasting permeabilities. The wetting front, however, arrives at this point and at the depths of 8 and 13.5 feet $(2.4$ and $4.1 \mathrm{~m})$ on February 15 . The wetting front velocity in this instance appears to range between approximately 2.6 and 7.3 feet/day $(0.8$ and $2.2 \mathrm{~m} /$ day $)$.

One of the last pairs of resistance cells to respond to ground water infiltration from the February 11-19 storm is in the clean sand at a depth of 21 feet $(6.4 \mathrm{~m})$ in LR-2-R. Here the sandy soil is probably isolated from other coarse grained deposits and the capillary tension in the overlying silt prevents water from penetrating the sand until a relatively high moisture content is achieved. 
Periods of decreasing moisture content are commonly identified by the resistance data to occur after a maximum moisture content and before the passing of a new wetting front. This is well documented in the coarser grained soils and in the soils close to the ground surface. The coarse grained soils have a high saturated hydraulic conductivity which allows these soils to drain quickly. Between precipitation events evaporation of water to the atmosphere can reduce the moisture content below the field capacity in the surface deposits. Ground water percolation to the water table is minimal during the periods of drying because of the low hydraulic conductivities of soils under relatively low moisture conditions.

\section{Ground Water Recharge}

Ground water recharge at LLNL is highly episodic and related to storm events. In and immediately adjacent to the drainage retention basin a water table rise of up to 21 feet $(6.4 \mathrm{~m})$ is noticed within 2 weeks after a storm event (fig. 19). As the water table mounds under the basin, the increased hydraulic head causes the mound to propagate radially away from the basin. At greater distances away from the drainage retention basin the water table fluctuations due to 
vertical infiltration become increasingly damped by radial spreading (fig. 22). If there is no new inflow into the basin, then the water table below the basin decays to some level somewhat above its pre-storm elevation.

The development of the recharge mound under the drainage retention basin temporarily alters the ground water flow gradient near the center of LLNL. Figure 40 overlays several profiles of the water table between MW-142 and MW-101 during the study period. In the dry season (May to september), the water table gradient near LLNL is generally towards the west or northwest. In the wet season (October to April), however, a water table mound commonly develops under the basin (fig. 41). This mound may cause the up gradient and cross gradient ground water in the uppermost water-bearing zones to temporarily flow away from the basin until the water table mound has attenuated. On the sides of the water table mound the ground water flow velocity increases as the slope of the water table steepens.

The effect of the water table mound on the regional ground water gradient rapidly decreases with greater distances from the basin. overall, ground water recharge from the drainage retention basin increases the 










ground water flow velocity and causes the ground water in the uppermost water-bearing zones to flow away from the basin. The pattern of rising water levels at LLNI indicates that ground water recharge under the Arroyo Seco and Arroyo Las Positas combines with the recharge from the drainage retention basin by April of the study period (fig 24).

The ground water flow velocity can be calculated using the Darcy Equation:

$$
v=\frac{-k(d h / d I)}{n}
$$

where,

$$
\begin{array}{ll}
\mathrm{v}=\text { average linear velocity } & \left(L T^{-1}\right) \\
\mathrm{K}=\text { hydraulic conductivity } & \left(L T^{-1}\right) \\
\mathrm{n}=\text { effective porosity } & (, \\
\mathrm{dh} / \mathrm{dl}=\text { hydraulic gradient } & (\mathrm{l})
\end{array}
$$

The maximum ground water velocity near MW-10A would occur when dh/dl is the greatest. During the study period, this would occur on February 24, 1986, when the difference in water levels between the the area under the pond and at $M W-10 \mathrm{~A}$ was 15.5 feet $(4.7 \mathrm{~m})$ and $\mathrm{dh} / \mathrm{dl}$ was approximately 0.13 feet/foot. Analysis of two soil 
samples from the saturated zone and a slug test at MW-10A indicate that $\mathrm{n}$ can vary from $23 \%$ to $33 \%$ and $\mathrm{K}$ is $0.34 \mathrm{feet} /$ day (0.11 m/day) (Stone and Ruggieri, 1983). From this data the maximum $v$ near $M W-10 A$ during the study period is 0.13 to 0.19 feet/day $(0.04$ to 0.06 $\mathrm{m} /$ day). Maximum ground water velocities elsewhere around the basin may be greater than 20 feet/day ( 7 $\mathrm{m} /$ day) because hydraulic conductivities elsewhere in the drainage retention area can vary over 2 orders of magnitude greater (e.g. MW-224) than that at MW-10A. The faster flow rate, in turn, may enhance hydrodynamic dispersion or the spreading out and dilution of localized solutes over a larger area (Freeze and Cherry, 1979).

The law of conservation of mass requires a correlation between the volume of water which percolated from the pond and the amount of ground water recharge. The volume of water which percolated from the basin between February 11 and April 15, 1986, is at least 59.2 acre-feet (from Table 2). The total volume of soil and ground water in the recharge mound that developed during this period is approximately 750 acre-feet (fig. 24). If it is assumed that all of the percolated water is available to be extracted by wells, then, the volume of 
the percolated water could be used to calculate the specific yield. The ratio of the volume of percolated water over the volume of the recharge mound suggests an average specific yield of at least 0.08 for the material in the water table mound. This is a reasonable value for an unconfined aquifer (Freeze and Cherry, 1979). The actual specific yield value of a given water-bearing zone may be somewhat higher due to the inhibition of water to flow into zones of low permeability inside the water table mound. 


\section{CONCLUSION}

During the 1985-86 water year (the study period), ground water recharge from the drainage retention basin at LLNL was episodic and had a significant impact upon the underlying ground water flow regime. The amount of ground water recharge was dependent upon the depth of ponding in the basin or more generally upon the amount of precipitation and storm runoff. During this period, ponding over seven feet deep and inflowing of off-site runoff into the basin occurred during two intense storm periods (February 11-19 and March 7-15). Ground water recharge from the basin due to these two storms was estimated from the pond volume loss to be at least 59.3 acre-feet. In contrast, the pond volume loss totaled at least 17.5 acre-feet following six earlier, less intense, storm periods when there was no inflowing of off-site runoff and the basin was ponded to a lesser extent. Total precipitation during the 1985-86 water year was 16.8 inches which is slightly above average.

Based upon the water level fluctuations in MW-10A since 1980 (fig. 20), the amount of ground water recharge observed during the study period appears to be somewhat above average. Based upon the size of the water table mound which developed under the basin (fig. 24), it can be concluded that infiltration from the drainage 
retention basin during the 1985-86 water year recharged the ground water system at LLNL to a greater extent than any other source. Ground water infiltration from the Arroyo seco, however, affects to a much larger extent the area south and west of LLNL due to its larger watershed and high infiltration rates (zone 7, 1981). Some recharge along the Arroyo Las Positas is indicated by the storm related water level fluctuations in $M W-5$ and MW-5A. Infiltration along smaller drainage channels has been observed to locally affect the water table configuration.

Infiltration rates on the floor of the drainage retention basin, as measured in double-ring infiltrometer tests, varied between 0.004 and approximately 1 foot/day $(0.001$ and approximately $0.3 \mathrm{~m} / \mathrm{day})$. The lowest infiliration rates were encountered on recent accumulations of silt in low lying areas near $L R-4-P$ and the northeast corner of the basin (fig. 36). The higher infiltration rates are consistent with pond volume losses (up to 10.4 acre-feet/day) when the upper reaches of the pond are inundated. Factors that contribute to increased volumes of ground water recharge during high pond levels include greater hydraulic heads, higher infiltration rates at the upper reaches of the basin, and a larger surface area available for infiltration. 
Future ground water recharge from the basin will be restricted by the ongoing deposition of silt and clay on the basin floor and the installation of a drainage pipe at the north side of the basin during the summer of 1987. The drainage pipe will allow water to flow out of the basin when the pond becomes more than approximately 4 feet $(1.2 \mathrm{~m})$ deep, thus limiting both the area of infiltration and hydraulic head.

Ground water flow rates in the vadose zone at LLNL are highly variable and dependent upon the proximity of surface waters. Tritium profiles in areas away from ponded water and drainage channels suggest that water has not percolated to depths greater than approximately 40 feet $(12 \mathrm{~m})$ below the ground surface over the last 35 years. Significant ground water percolation and recharge from the drainage retention basin is evidenced by the tritium profile at LR-4-P which appears to be in equilibrium with recent atmospheric water and by the development of a water table mound under the basin during the wet season.

The ground water flow rates in the vadose zone under the drainage retention basin are also dependent upon the physical properties (i.e. moisture content and grain size distribution) of the soil and its spatial variability. Under high pond level conditions the volume 
and rate of percolation is probably greater at the east and west ends of the basin because here the basin is underlain by more permeable sediments than under the central portion of the basin (fig. 17). Water which percolates to the water table near the east and west ends of the basin would then flow laterally towards areas of lower pressure head (i.e. the central portion of the basin and away from the basin). This is confirmed by the fact that the water levels in $M W-119$ and $L R-4-P$ commonly rise prior to noticing a change in electrical resistance or moisture content of soil monitored by the resistance cells below a depth of 28 feet $(8.5 \mathrm{~m})$ in the central portion of the basin. Flow rates as high as 17 feet/day $(5 \mathrm{~m} /$ day) are indicated by the fact the water table usually starts to rise 3 days after the onset of a significant storm.

On several occasions the network of resistance cells below the basin has delineated the downward progression of a wetting front between the depths of 2 and 30 feet $(0.6$ and $9 \mathrm{~m}$ ) over a period of 1.5 to 3 days. Unsaturated coarse grained deposits near a depth of 30 feet $(9 \mathrm{~m})$ between $L R-1-R$ and $L R-4-P$ and near a depth of 20 feet $(6 \mathrm{~m})$ at $L R-2-R$ appear to initially hinder the progression of a wetting front (figs. 29, 30, and 34 ). However, the coarse grained soils often begin 
to dry sooner than fine grained soils which generally have relatively constant and high year-round moisture contents.

The ground water flow rates in the uppermost water-bearing zones near the drainage retention basin are also variable. During summer months the hydraulic gradient in the upper water-bearing zones below the basin is approximately 0.0035 feet/foot or $0.35 \%$ towards the west. When the ground water mound develops below the basin in the winter months, the ground water in the upper water-bearing zones flows radially away from the basin. Instantaneous ground water flow rates can range between. 0.0 and over 25 feet/day $(0.0$ and over $7.5 \mathrm{~m} /$ day) due to the fact that the hydraulic conductivity and hydraulic gradient in the water-bearing zones at ILNL can vary over several orders of magnitude. Ground water may flow eastward (in the opposite direction of the regional pattern) for as much as 700 feet $(215 \mathrm{~m})$ away from the east side of the basin, if a water table mound similar to the size of that in April 1986 develops (fig. 41). 


\section{REFERENCES CITED}

Allison, L.E., 1947, Effect of microorganisms on the permeability of soils under prolonged submergence: Soil Science, v. 63, p. 82-93.

Carpenter, D.W., 1984, Assessment of contamination in soils and groundwater at Lawrence Livermore National Laboratory, Sandia National Laboratory, and adjacent properties: Lawrence Livermore National Laboratory, Livermore, CA, UCAR-10180, 206 p.,

Carpenter, D.W., Clark, R.J., Peifer, D.W., Qualheim, B.J., Ramirez, A.L., Rogers, L.L. Sweeney, J.J., and Wagoner, J.L., 1982, Geologic data report, Lawrence Livermore National Laboratory Site: Lawrence Livermore National Laboratory, Livermore, CA, UCID-19666, 215 p.

Carpenter, D.W., Puchlik, K.P., Ramirez, A.L., Wagoner, J.L., Knauss, K.G., and Kasameyer, P.W. 1980, status report on the geology of the Lawrence Livermore National Laboratory site and adjacent areas: Lawrence Livermore National Laboratory, Livermore, CA, UCLR-53065, 2 vols.,
$97 \mathrm{p}$.

Carpenter, D.W., Sweeney, J.J., Kasameyer, P.W., Burkhard, N.R., Knauss, K.G., and Shlemon, R.J., 1984, Geology of the Lawrence Livermore National Laboratory site and adjacent areas: Lawrence Livermore National Laboratory, Livermore, CA, UCRL-53316, $150 \mathrm{p}$.

CDWR, 1966, Livermore and Sunol Valleys, evaluation of ground water resources, appendix A: geology: Bulletin 118-2, State of California, Department of Water Resources, Sacramento, CA, 79 p.

CDWR, 1974, Evaluation of ground water resources: Livermore and Sunol Valleys: Bulletin 118-2, State of California, Department of water Resources, Sacramento, CA, $153 \mathrm{p}$.

Constantz, Jim, 1983, "Adequacy of a compact double-cap infiltrometer compared to the ASTM double-ring infiltrometer", in Proceedings of Infiltration, December 11-12, 1983, Chicago, IL: American Society of Agricultural Engineers, $p$.
$226-230$. 
Davies, T.S., 1981, A groundwater model analysis of the Amador Subbasin of the Livermore Valley, California (Master's Thesis): Stanford University, $140 \mathrm{p}$.

Dibblee, T.W., Jr., 1980, A preliminary map of the Altamont Quadrangle, Alameda County, California: U.S. Geological Survey, Denver, Co, Open-File Report 80-538, 1 sheet with legend

Dreicer, Mona, 1985, Preliminary report on the past and present uses, storage, and disposal of hazardous materials and wastes on the Lawrence Livermore National Laboratory: Lawrence Livermore National Laboratory, Livermore, CA,
UCID-20442, 115 p.

Dresen, M.D, and Hoffman, Fredric, 1986, Volatile organic compounds in ground water west of LINL: Lawrence Livermore National Laboratory, Livermore, CA, UCRL-53740, $46 \mathrm{p}$.

Dresen, M.D., and Nichols, E.M., 1986, Distribution of Vocs in ground water in the southeast area of LLNL and vicinity: Prepared by Weiss Associates, Inc., Berkeley, CA, for Lawrence Livermore National Laboratory, Livermore, CA,
UCID-20917, $62 \mathrm{p}$.

Dresen, M.D., Nichols, E.M., McConachie, W.A., Buchanan, K.S., and Isherwood, W.F., 1987, Draft remedial alternatives for vocs in ground water west of LLNL: Lawrence Livermore National Laboratory, Livermore, CA, UCAR-10202, 101 p.

Everett, L.G., Wilson, L.G., and Hoylman, E.W., 1983, Vadose zone monitoring, for hazardou's waste sites: Prepared by Kaman Tempo, Santa Barbara, CA, for Environmental Monitoring Systems Laboratory, office of Research and Development, U.S. Environmental protection Agency, Las Vegas, NV, KT-82-018(R), $358 \mathrm{p}$.

Freeze, R.A., and Banner, J., 1970, The mechanism of natural groundwater recharge and discharge: 2 . laboratory column experiments and field measurements: Water Resources Research, v. 8,
no. 6, p. 138-155.

Freeze, R.A., and Cherry, J.A., 1979, Groundwater: Prentice-Hall, Inc., Englewood Cliffs, NJ, $604 \mathrm{p}$. 
Gvirtzman, Haim, and Magaritz, Mordeckai, 1986, Investigation of water movement in the unsaturated zone under an irrigated area using environmental tritium: Water Resources Research, v. 22, no. 5, p. 635-642.

Herd, D.G., 1977, Geologic map of the Las Positas, Greenville, and Verona Faults, eastern Alamedá County, California: U. S. Geologic Survey, Open-File Report 77-689, 24 p.

Huey, A.S., 1948, Geology of the Tesla Quadrangle, California: California Division of Mines, Bulletin $140,75 \mathrm{p}$.

Lawrence Livermore National Laboratory, 1984, Phase II: ground water investigation workplan: PhN Livermore site: Lawrence Livermore National Laboratory, Livermore, CA, 2 vols., 349 p.

Littlefield, David, 1985, X-Division drainage channel analysis (informal report): prepared by Civil Engineering Group, Lawrence Livermore National Laboratory, Livermore, $C A, 81$ p.

Lukens, R.P., (Ed.), 1981, Annual book of ASTM standards, part 19 soil and rock; building stones, p. 509-514.

Martin, Brian, and Fagundes, Stephen, 1972, Urban water resources management through artificial recharge: Davis, University of California, Department of water Science and Engineering, 22 p.

Olsen, J.V.' (1978), "Treatment of primary effluent by rapid infiltration", in Proceedings of National Conference of Environmental Engineering, Research Development, and Design, American 12, 1978, Kansas City, Mo: New York, American Society of Civil Engineers, p. 357-361.

Qualhiem, B.J., 1988, Well $\log$ report for the LLNL Ground Water Project, 1984-1987: Lawrence Livermore National Laboratory, Livermore, CA,
UCID-21342, 11 p.

Richter, R.C., and Chun, R.Y.D., 1959, Artificial recharge of ground-water reservoirs in California: American Society of Civil Engineers, 85 (IR 4): 1-27 
Rogers, L.L., 1982, Water table configuration below the Lawrence Livermore National Laboratory site and its surrounding sections: Lawrence Livermore National Laboratory, Livermore, CA, $24 \mathrm{p}$.

Scalmanini, J.C., and Scott, V.H., 1979, Design and operational criteria for artifical groundwater recharge facilities: Davis, University of California, Department of Land, Air and water Resources, Water Science and Engineering Paper No. 2009, 93 p.

Sorenson, S.K., Casoc, P.V., and Glass, R.I., 1985, Water-quality conditions and an evaluation of ground- and surface-water sampling in the Livermore-Amador Valley, California: U.S. Geological survey, Sacramento, CA, Water-Resources Investigations Report 84-4352,
$34 \mathrm{p}$.

Stone, Randolf, Ruggieri, M.R, Rogers, L.L., Emerson, D.O., and Buddemeier, R.W., 1982 , Potential for saturated ground-water system contamination at the Lawrence Livermore National Laboratory: Lawrence Livermore National Laboratory, Livermore, CA, UCRL-53426, 105 p.

Stone, Randolf, and Ruggieri, M.R., 1983, water quality and movement at Lawrence Livermore National Laboratory, Lawrence Livermore National Laboratory, CA, UCRL-53474, $18 \mathrm{p}$.

Sweeney, J.J., and Springer, J.E., 1981, Geology of the southeastern Livermore Vaíley, Alameda County, California: Lawrence Livermore National Laboratory, Livermore, CA, UCRL-53200, 52 p.

Thorpe, R.K. Isherwood, W.F., Dresen, M.D., Webster-Scholten, C.P., Eds., 1990, Draft CERCLA remedial investigations report for the LLNL-Livermore site: Lawrence Livermore National Laboratory, Livermore, CA, UCAR-10299, Vol. $1,400 \mathrm{p}$.

Todd, D.K., Bouwer, Herman, Priestaf, Iras, and Warner, D.L., 1988, Artificial recharge of groundwater, notes for seminar given in Anaheim, CA, 2914 Domingo Avenue, Berkeley, CA, 221 p. 
University of California, 1986, Draft environmental impact report for the University of California contract with the Department of Energy for operation and management of Lawrence Livermore National Laboratory: University of California, Berkeley, CA, SCH-85112611, $190 \mathrm{p}$.

U.S. Department of Agriculture, 1966, Soil survey: Alameda County, California: U.S. Department of Agriculture, Soil Conservation Service, in cooperation with California Agricultural Experiment Station, Series 1961, No. 41, 93 p.

U.S. Department of Agriculture, 1970, Ground-water recharge hydrology: Agricultural Research Service, washington D.C., ARS 41-161, 62 p.

U.S. Department of Energy, 1982, Final environmental impact statement: Lawrence Livermore and Sandia National Laboratories-Livermore sites, Livermore, California: U.S. Department of Energy, Washington, D.C., DOE/EIS-0028, 693 p.

U.S. Department of Interior, 1980, Earth manual, a water resources technical pubíication, ( 2 ed.): U.S. Government Printing office, Washington D.C. , 810 p.

Webster-Scholten, C.P., Dresen, M.D., McConachie, W.A., Devany, R.O., Thompson, D.S., and Homan D.N. , 1987, LLNL Ground Water Project: Monthly Progress Report, March 15 - April 15, 1987: Lawrence Livermore National Laboratory, Livermore, CA, UCAR-10160-87-5, $30 \mathrm{p}$.

Webster-Scholten, C.P., and Hall, C.H., 1989, Work plan, Lawrence Livermore National Laboratory, Livermore site: CERCLA remedial investigation/ feasibility study: Lawrence Livermore National Laboratory, Livermore, CA, UCAR-10225, $163 \mathrm{p}$.

Weiss Associates, 1985, Annual report for fiscal year 1985 , ground water investigation at Livermore, Californ National Laboratory, National, California: Lawrence Livermore 2 vols., $203 \mathrm{p}$. 
Zone 7 (July 20, 1981), Groundwater conditions in the Seco Plain (internal memorandum): Zone 7 . Alameda county Flood Control and Water Conservation District, Livermore, $C A, 4 \mathrm{p}$.

Zone 7 (April 5, 1983), Artificial recharge releases, 1962-73 water years (internal memorandum): Zone 7, Alameda county Flood Control and Water Conservation District,
Livermore, CA, $3 \mathrm{p}$.

Zone 7, March 28, 1985, Basin yield, (internal memorandum): Zone 7, Alameda County Flood Control and Water Conservation District, Livermore, $C A, 10 \mathrm{p}$. 
APPENDIX A

BOREHOLE LOGS 
BOREHOLE MUHER: LR-1-R

BOGEHOLE LOCATIOA: SQUTH-CENTRAL PORTIOW OF IME DRAIMAGE RETEUTION BASIN, LLIL SITE





INCHES OF CORE RECOVERED



Figure 42. Log of Borehole LR-1-R. 
BOREHOLE NUMBERI LR-2-R

BOREHOLE LOCATION: CENTRAL PORTION OF THE DRAIMAGE RETEMTION BASIN, LLML SITE





INCHES OF CORE RECOUERED



Figure 43. Log of Borehole LR-2-R. 
BOREHOLE MUMBER: LR-J-R


Figure 44. Log of Borehole LR-3-R. 




Figure 45. Log of Piezometer LR-4-P. 
APPENDIX B

WELL COMPLETION AND

HYDRAULIC CONDUCTIVITY DATA 
APPENDIX B

Table 7. Well completion and hydraulic conductivity data for selected wells at LLNL.

\begin{tabular}{|c|c|c|c|c|c|}
\hline $\begin{array}{l}\text { We11 } \\
\text { Name }\end{array}$ & $\begin{array}{l}\text { Screened } \\
\text { Interval(1) }\end{array}$ & $\begin{array}{l}\text { Sand } \\
\text { Pack } \\
\text { Interval(1) }\end{array}$ & $\begin{array}{l}\text { Water- } \\
\text { Bearing } \\
\text { Zone }\end{array}$ & $\begin{array}{l}\text { Hydrauli } \\
\text { Conducti } \\
\text { al/d/ft }\end{array}$ & $\begin{array}{l}\text { ity } \\
\mathrm{ft} / \mathrm{d}\end{array}$ \\
\hline$L R-4-P$ & $66-46$ & $66-41$ & First & na & na \\
\hline MW - 1 & $\begin{array}{l}95-100 \\
104-114\end{array}$ & $75-116$ & First & 170 & 22.8 \\
\hline$M W-1 A$ & $145-155$ & $144-156$ & Second & 19 & 2.55 \\
\hline MW- 2 & $86-101$ & $64.5-101$ & First & 34 & 4.53 \\
\hline$M W-2 A$ & $150-164$ & $150-185$ & $\begin{array}{l}\text { Third and } \\
\text { Fourth }\end{array}$ & 200 & 26.8 \\
\hline$M W-4$ & $75-90$ & $58.5-92$ & First & 13.2 & 1.77 \\
\hline$M W-5$ & $\begin{array}{l}56-71 \\
81-86\end{array}$ & 49.90 & First & 20 & 2.68 \\
\hline$M W-5 A$ & $95-105$ & $94-115$ & Second & 130 & 17.4 \\
\hline MW - 7 & $\begin{array}{l}76-81 \\
88-98\end{array}$ & $67.5-100.5$ & $\begin{array}{l}\text { Second and } \\
\text { Third(2) }\end{array}$ & 14.0 & 1.87 \\
\hline $\mathrm{MW}-10 \mathrm{~A}$ & $\begin{array}{l}85-95 \\
100-105\end{array}$ & $68-110$ & $\begin{array}{l}\text { First thru } \\
\text { Third }\end{array}$ & 2.7 & 0.36 \\
\hline $\mathrm{MW}-12$ & $99-114$ & $77-115$ & First & na & na \\
\hline MW - 17 & $94-109$ & $82.5-114$ & First & 2.5 & 0.33 \\
\hline MW-17A & $\begin{array}{l}127-132 \\
147-157\end{array}$ & $108-165$ & $\begin{array}{l}\text { Second and } \\
\text { Third }\end{array}$ & na & na \\
\hline MW - 18 & $\begin{array}{l}80-90 \\
100-105 \\
112-117 \\
127-132 \\
142.5-152.5\end{array}$ & $68.5-105$ & $\begin{array}{l}\text { First thru } \\
\text { Fourth (3) }\end{array}$ & 2.7 & 0.36 \\
\hline
\end{tabular}


Table 7 (continued).

\begin{tabular}{|c|c|c|c|c|c|}
\hline $\begin{array}{l}\text { Well } \\
\text { Name } \\
\ldots \ldots\end{array}$ & $\begin{array}{l}\text { Screened } \\
\text { Interval (1) }\end{array}$ & $\begin{array}{l}\text { Sand } \\
\text { Pack } \\
\text { Interval(1) }\end{array}$ & $\begin{array}{l}\text { Water- } \\
\text { Bearing } \\
\text { Zone }\end{array}$ & $\begin{array}{l}\text { Hydraulic } \\
\text { Conductiv } \\
\text { gal/d/ft }\end{array}$ & $\begin{array}{l}\text { vity } \\
\mathrm{ft} / \mathrm{d}\end{array}$ \\
\hline MW - 19 & $147-157$ & $133-161$ & First & na & na \\
\hline MW - 101 & $62-72$ & $59-72$ & First & na & na \\
\hline MW - 105 & $42-62$ & $41-62$ & First & na & na \\
\hline MW - 106 & $127.5-134.5$ & $125.5-137.5$ & First & 1.3 & 0.17 \\
\hline MW-107 & $115-122$ & $114-122$ & First & na & na \\
\hline MW-113 & $100-115.5$ & $98-115.5$ & First & 1.2 & 0.16 \\
\hline MW- 114 & $51-63$ & $50-63$ & First & na & na \\
\hline MW-116 & $86-91$ & $85-91$ & First & 7.5 & 1.00 \\
\hline MW - 117 & $138-148$ & $137-148$ & First & 0.4 & 0.05 \\
\hline MW - 119 & $87.5-102.5$ & $86-102.5$ & Second & 100 & 13.4 \\
\hline MW-141 & $45-60$ & $41-60$ & First & na & na \\
\hline MW-142 & $62-72$ & $59-72$ & First & 330 & 44.2 \\
\hline$M W-146$ & $115-125$ & $113-125$ & Second & na & na \\
\hline MW - 147 & $77-87$ & $75-87$ & First & na & na \\
\hline$M W-148$ & $83-98$ & $80-98$ & First & na & na \\
\hline$M W-204$ & $100-110$ & $99-110$ & First & 15 & 2.00 \\
\hline MW - 206 & $106-118$ & $105-118$ & Second & 11 & 1.47 \\
\hline MW - 207 & $69-85$ & $68-85$ & First & 32 & 4.29 \\
\hline MW-212* & $124-136$ & $122-136$ & First & 3.1 & 0.41 \\
\hline$M W-220 *$ & $82.5-92.5$ & $77.5-92.5$ & First & 5.5 & 0.74 \\
\hline $\mathrm{MW}-221 *$ & $82-95$ & $81-95$ & First & 16 & 2.14 \\
\hline
\end{tabular}


Table 7 (continued).

\begin{tabular}{|c|c|c|c|c|c|}
\hline $\begin{array}{l}\text { We1l } \\
\text { Name } \\
.\end{array}$ & $\begin{array}{l}\text { Screened } \\
\text { Interval (1) }\end{array}$ & $\begin{array}{l}\text { Sand } \\
\text { Pack } \\
\text { Interval (1) }\end{array}$ & $\begin{array}{l}\text { Water- } \\
\text { Bearing } \\
\text { Zone }\end{array}$ & $\begin{array}{r}\text { Hydrauli } \\
\text { Conducti } \\
\text { gal/d/ft } 2\end{array}$ & ft/d \\
\hline$M W-222 *$ & $63-83$ & $61-83$ & First & 160 & 21.4 \\
\hline $\mathrm{MW}-224 x$ & $78-88$ & $76-88$ & First & 400 & 53.6 \\
\hline$M W-255$ & $115-124$ & $113-124$ & First & 180 & 24.1 \\
\hline MW - 256 & $132-136.5$ & $130-136.5$ & Second & 5.5 & 0.74 \\
\hline MW - 257 & $82.5-96.5$ & $79-96.5$ & First & 12 & 1.61 \\
\hline MW - 258 & $116.5-121.5$ & $114-121.5$ & Third & 8 & 1.07 \\
\hline MW - 259 & $93.5-99$ & $92.5-99$ & First & 5.0 & 0.67 \\
\hline $\mathrm{MW}-273 *$ & $64-84$ & $62-84$ & First & 90 & 12.1 \\
\hline MW - 351* & $146-151$ & $144-151$ & Fourth & 14 & 1.87 \\
\hline
\end{tabular}

Notes:

(1) Feet below ground surface.

(2) MW-7 first water-bearing zone dry in 1981.

(3) MW-18 first water-bearing zone dry in 1981. We11 extended in May 1981. Well destroyed in November 1985.

na Data not available

* Well installed after March 1, 1986

From Rogers, 1982; Carpenter et a1.; 1982; Stone and Ruggieri, 1983; Webster-Scholten et al., 1987; and Qualheim, 1988. 
APPENDIX C

HYDROGRAPHS 


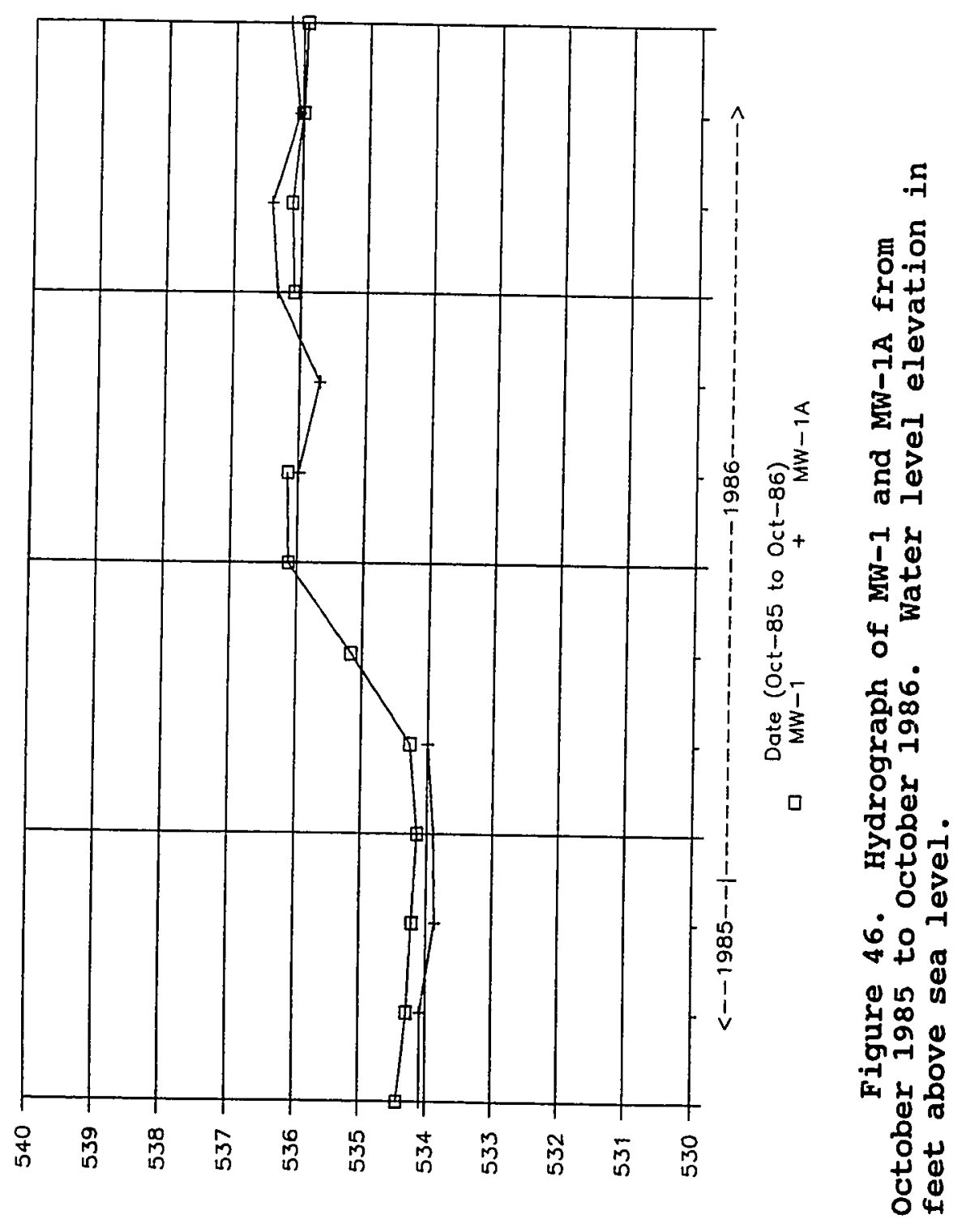













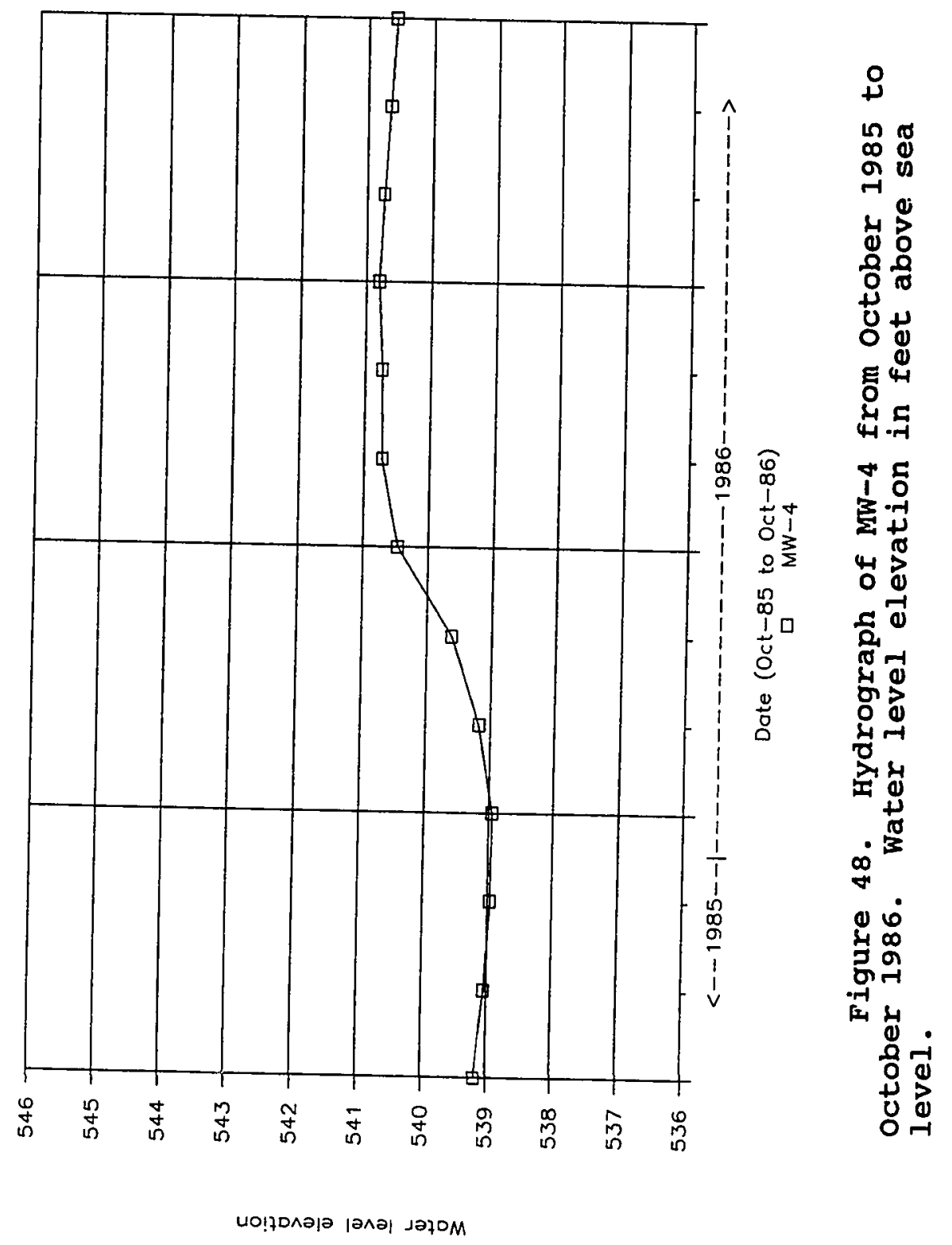


























145









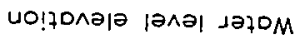










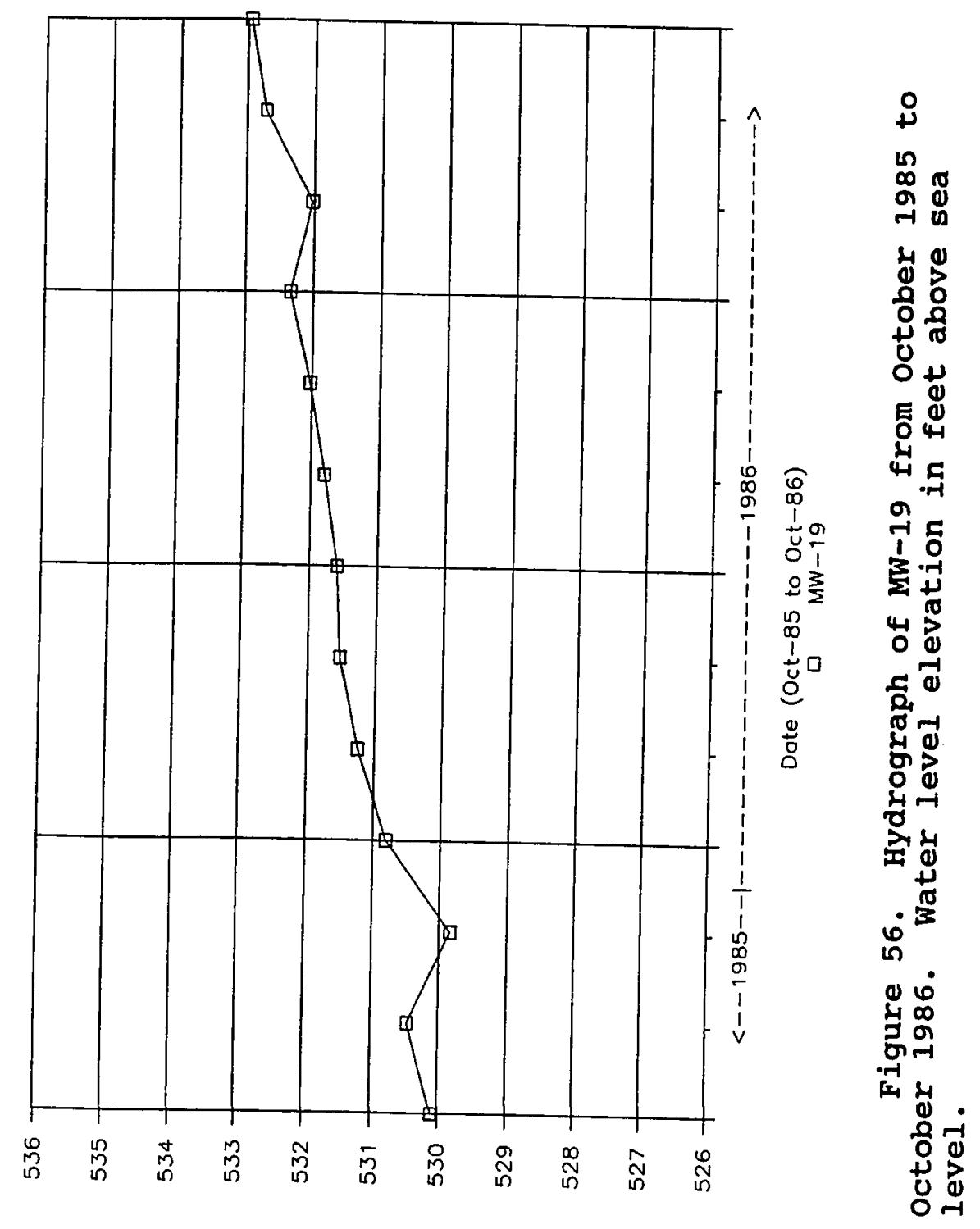

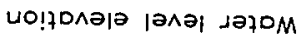



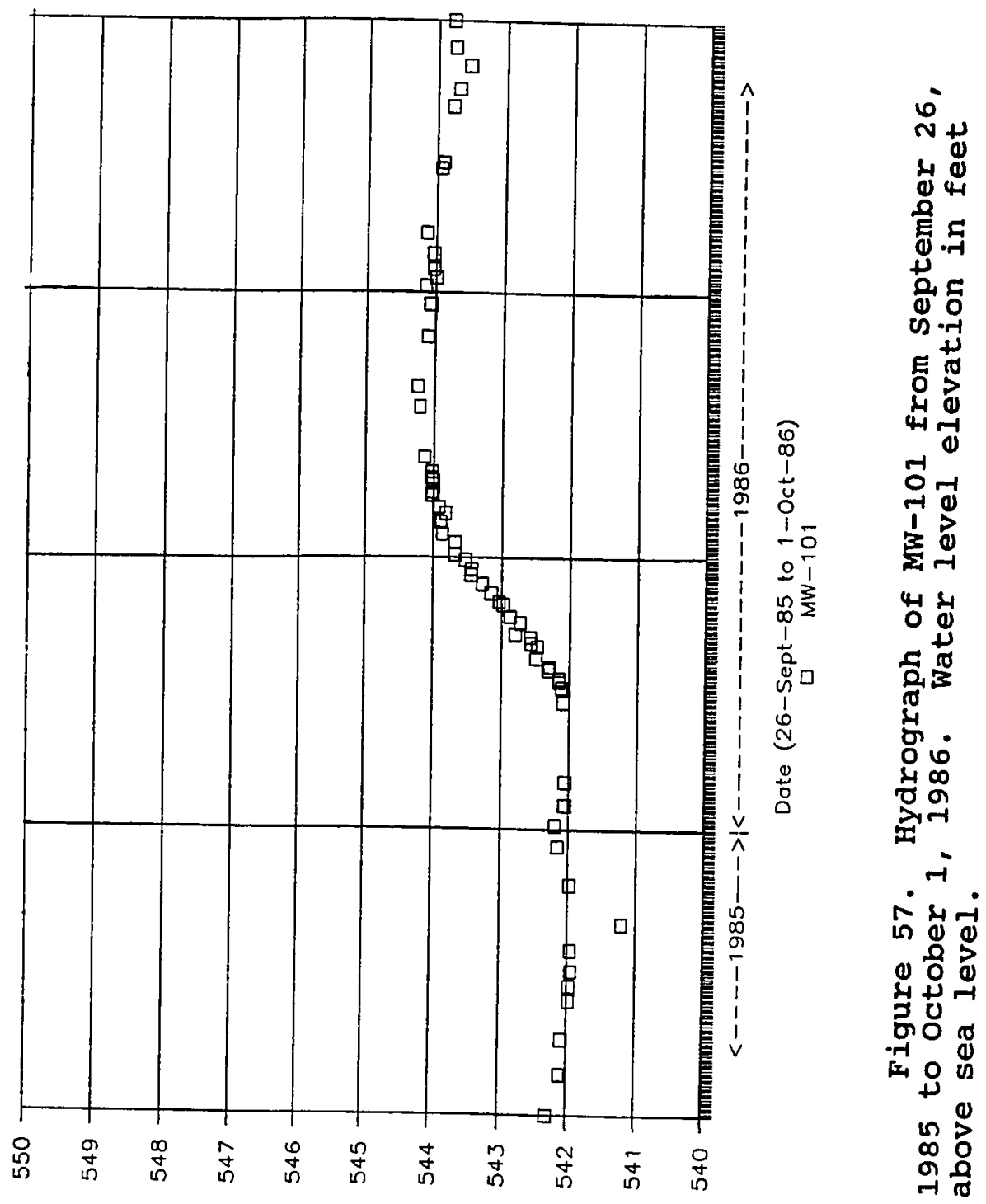

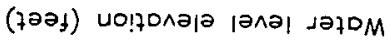


150

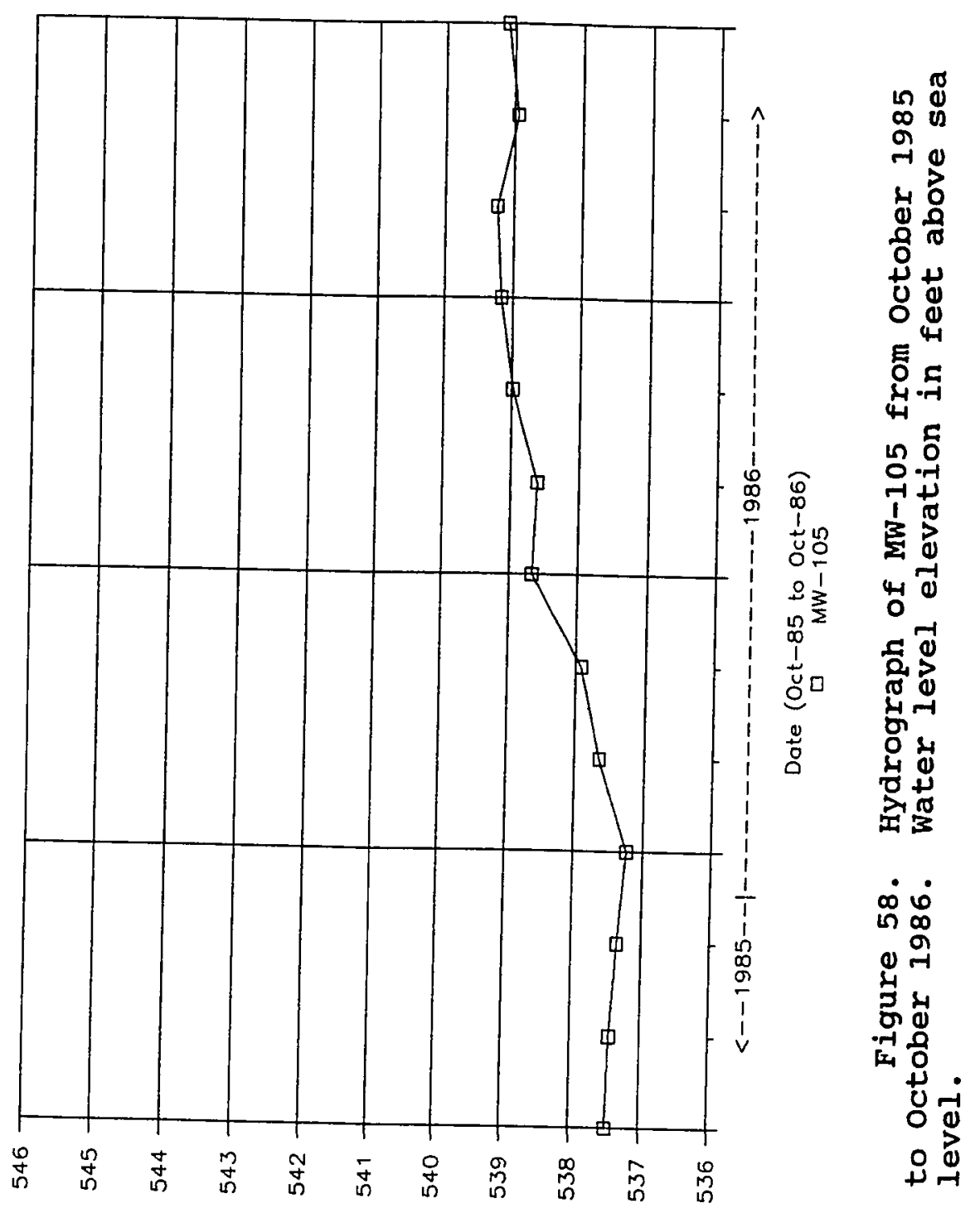




151













153






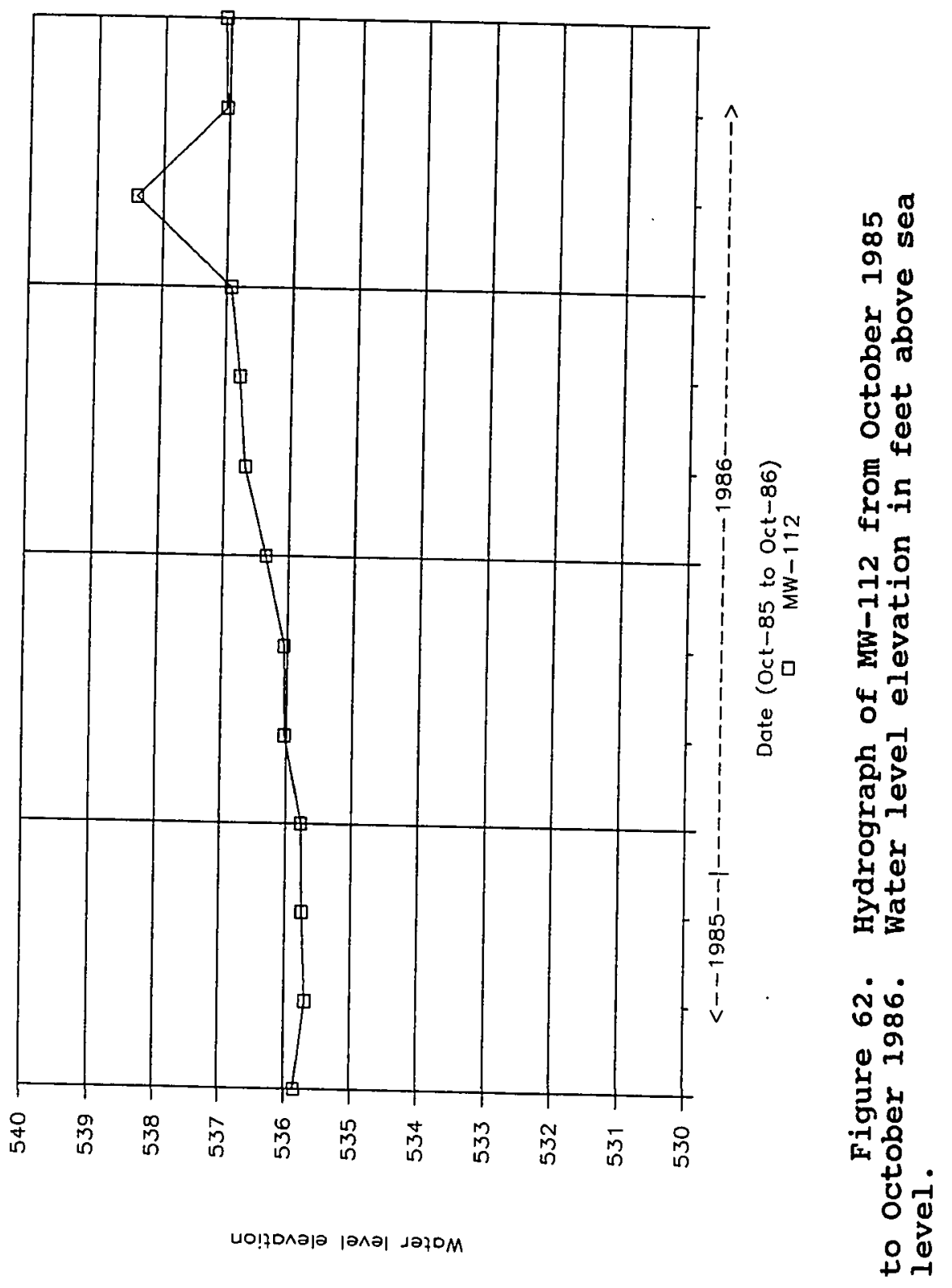




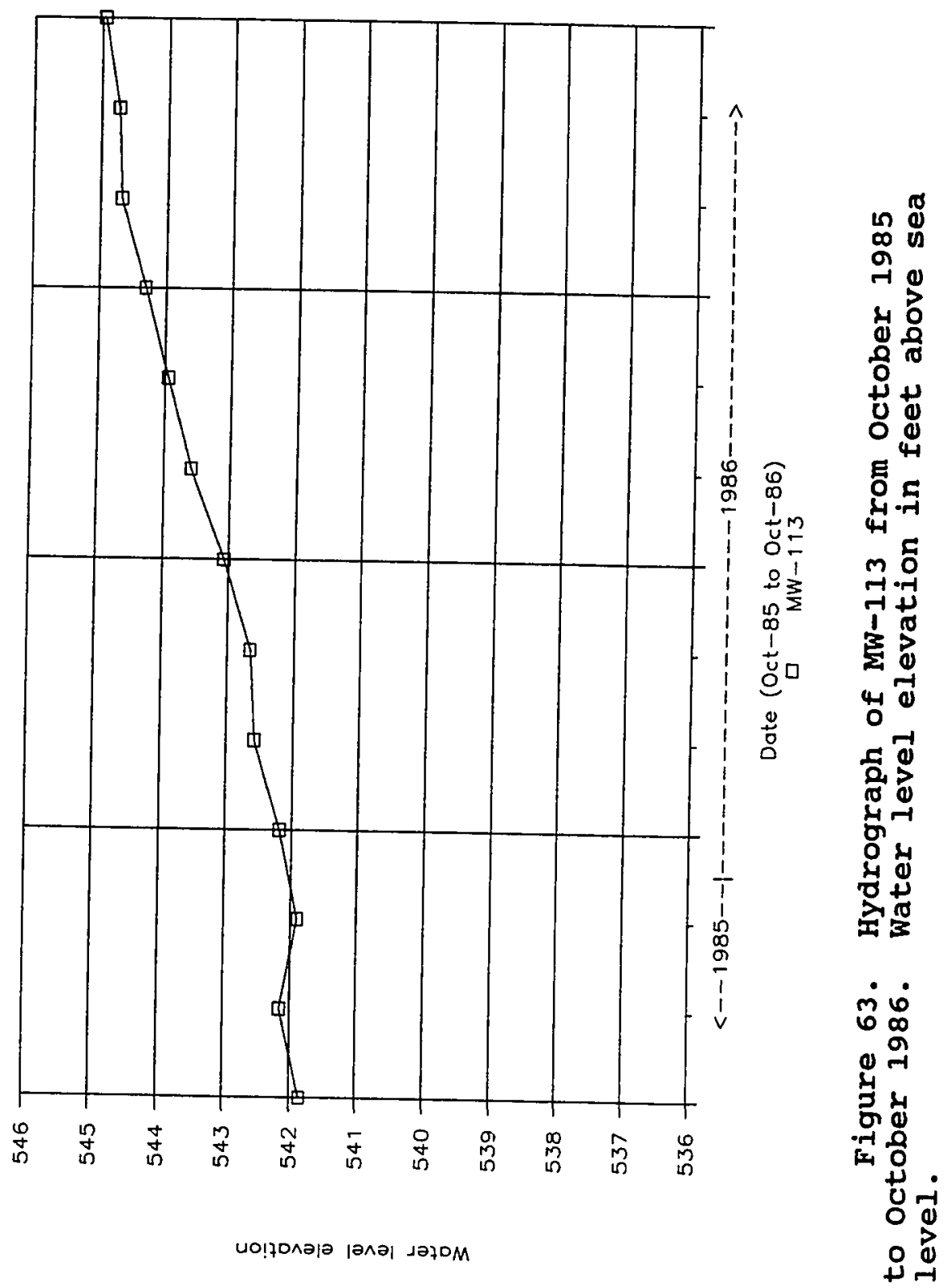











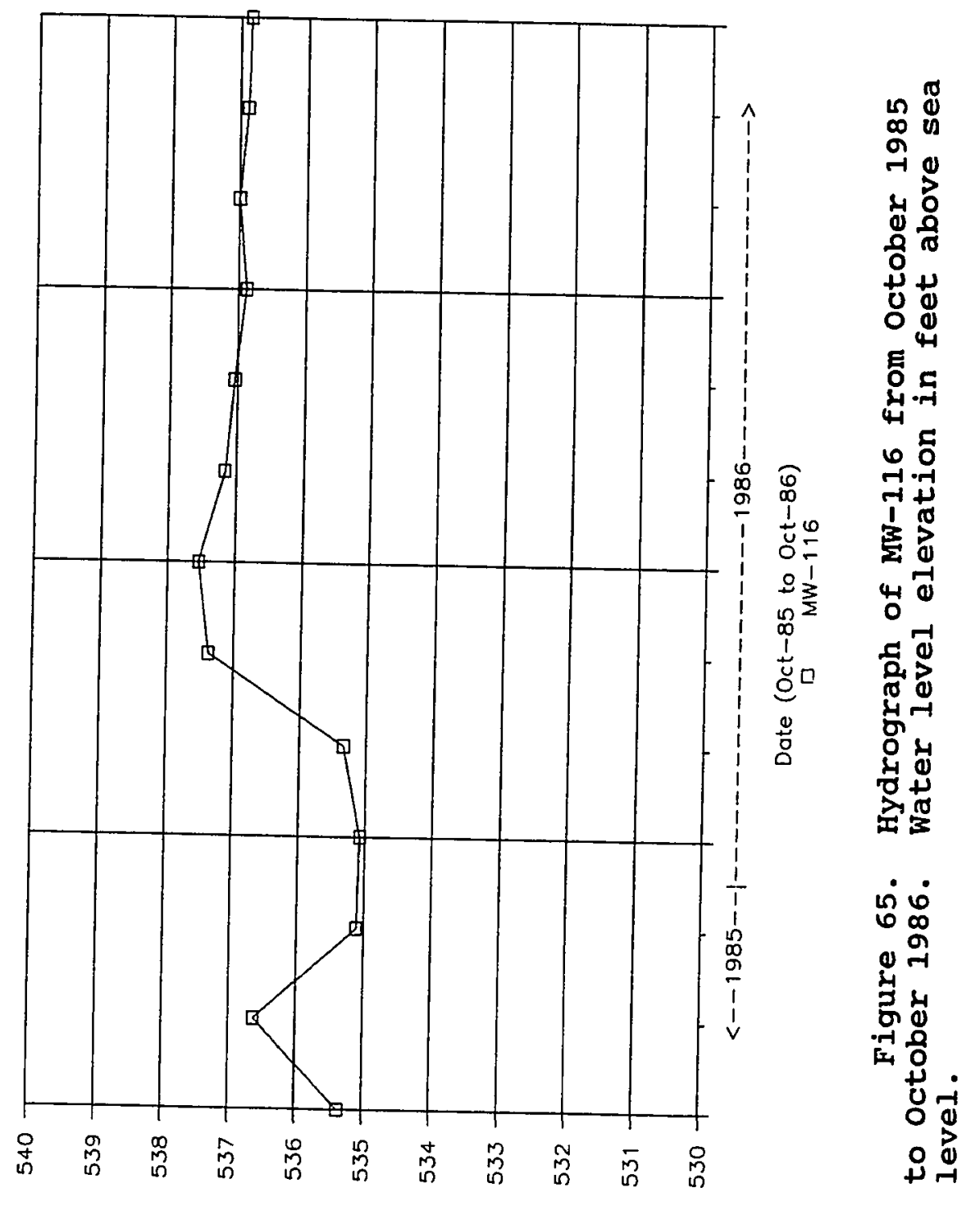























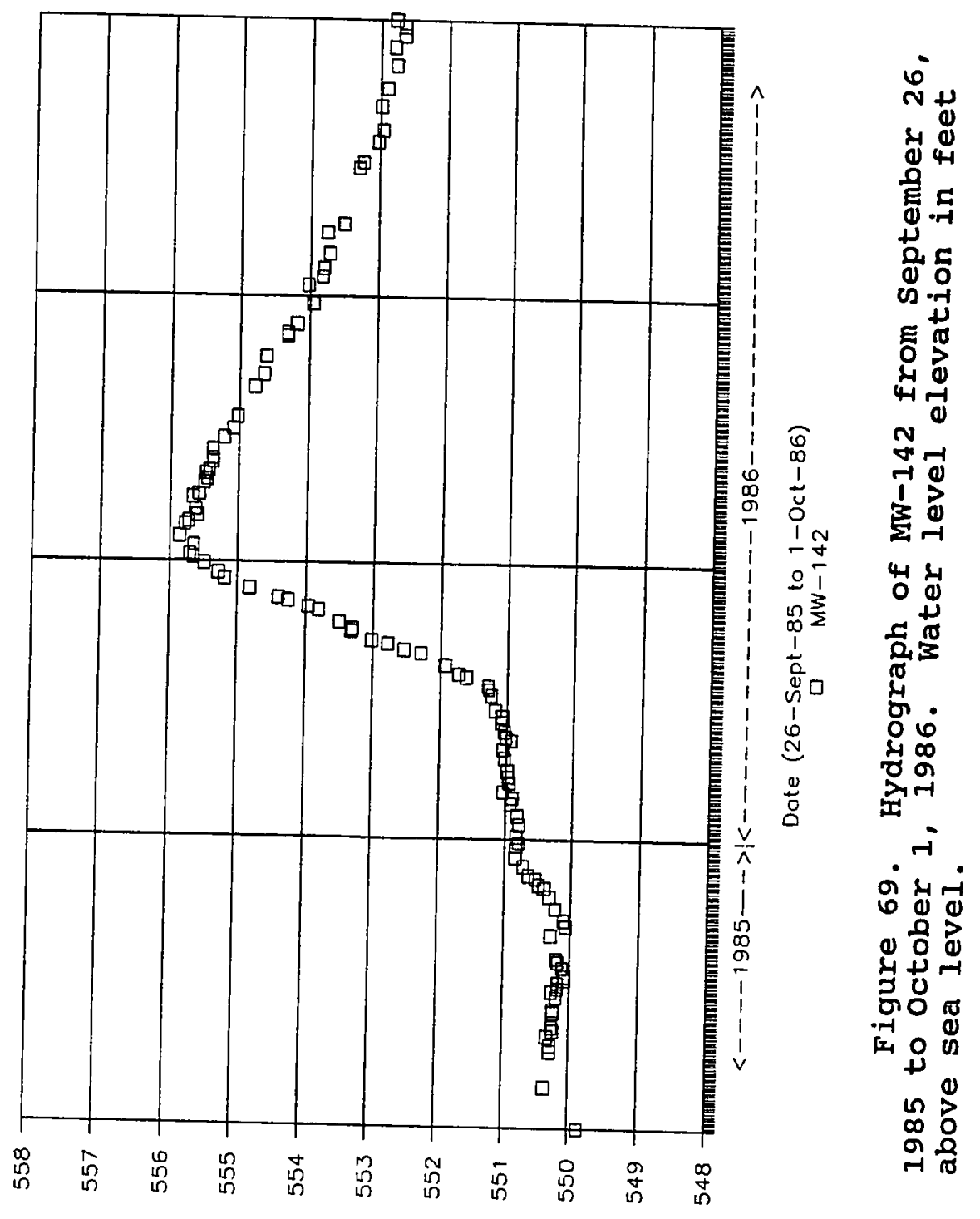



























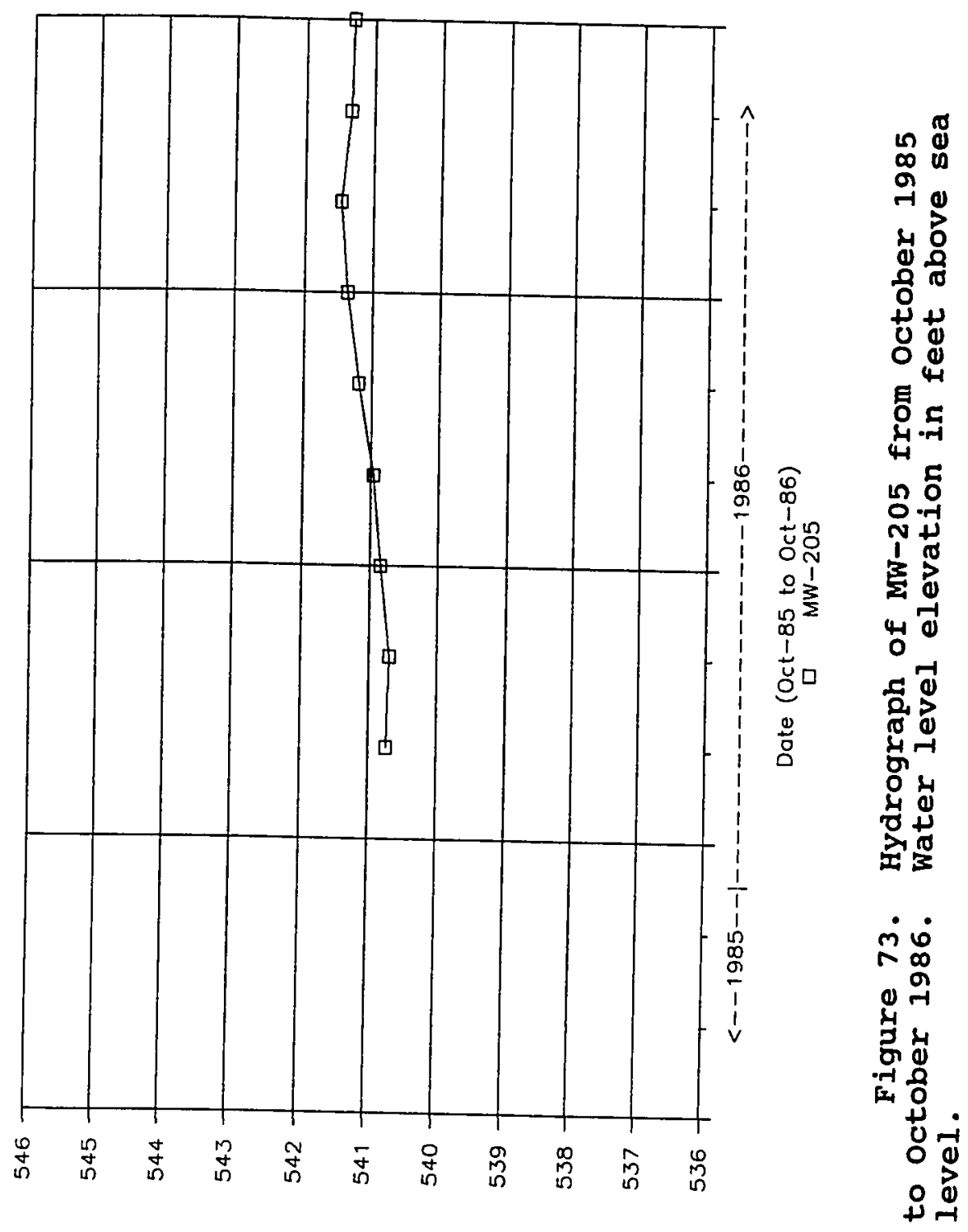




166




























171



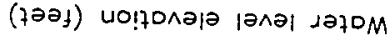



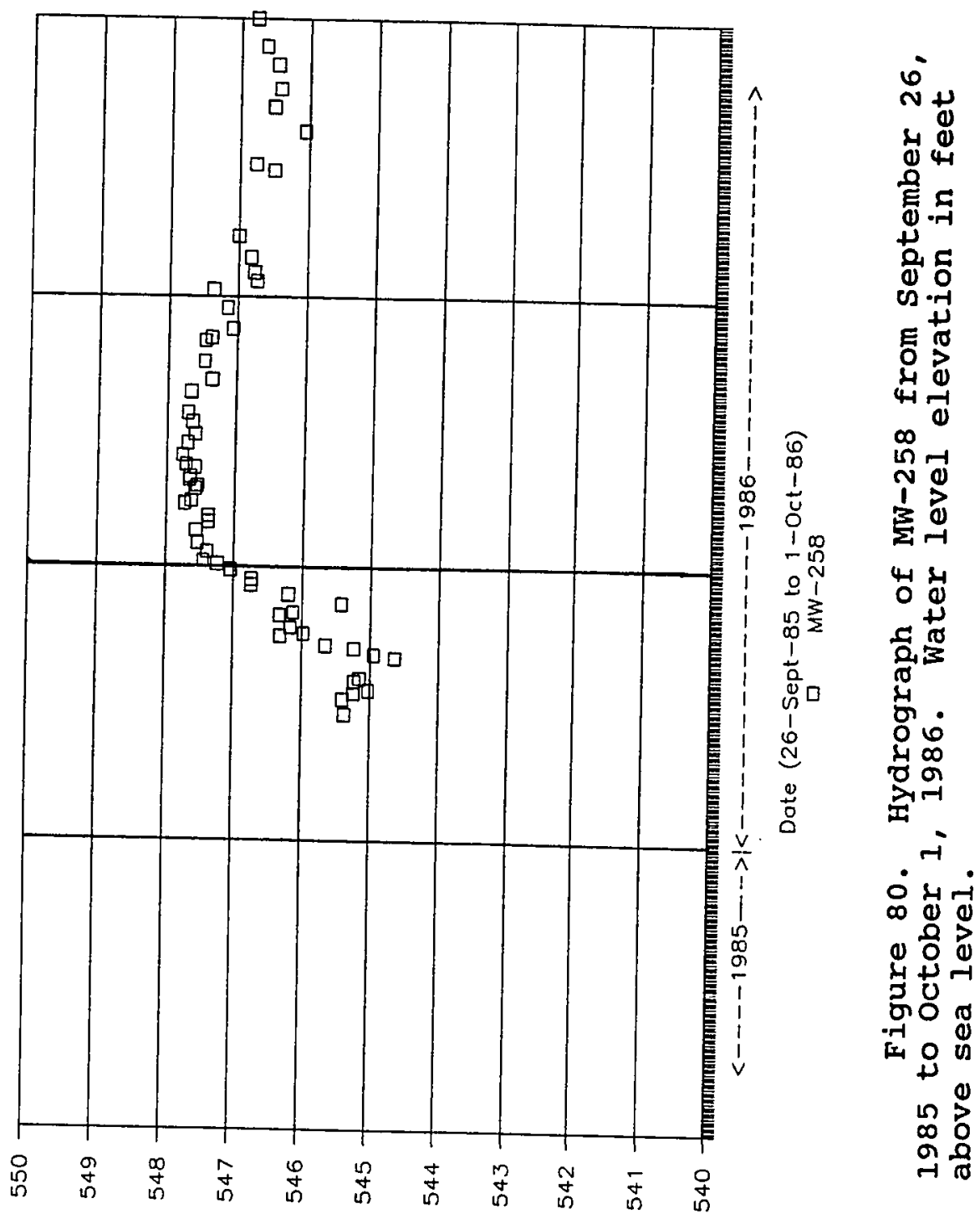

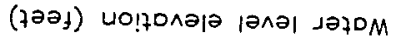


















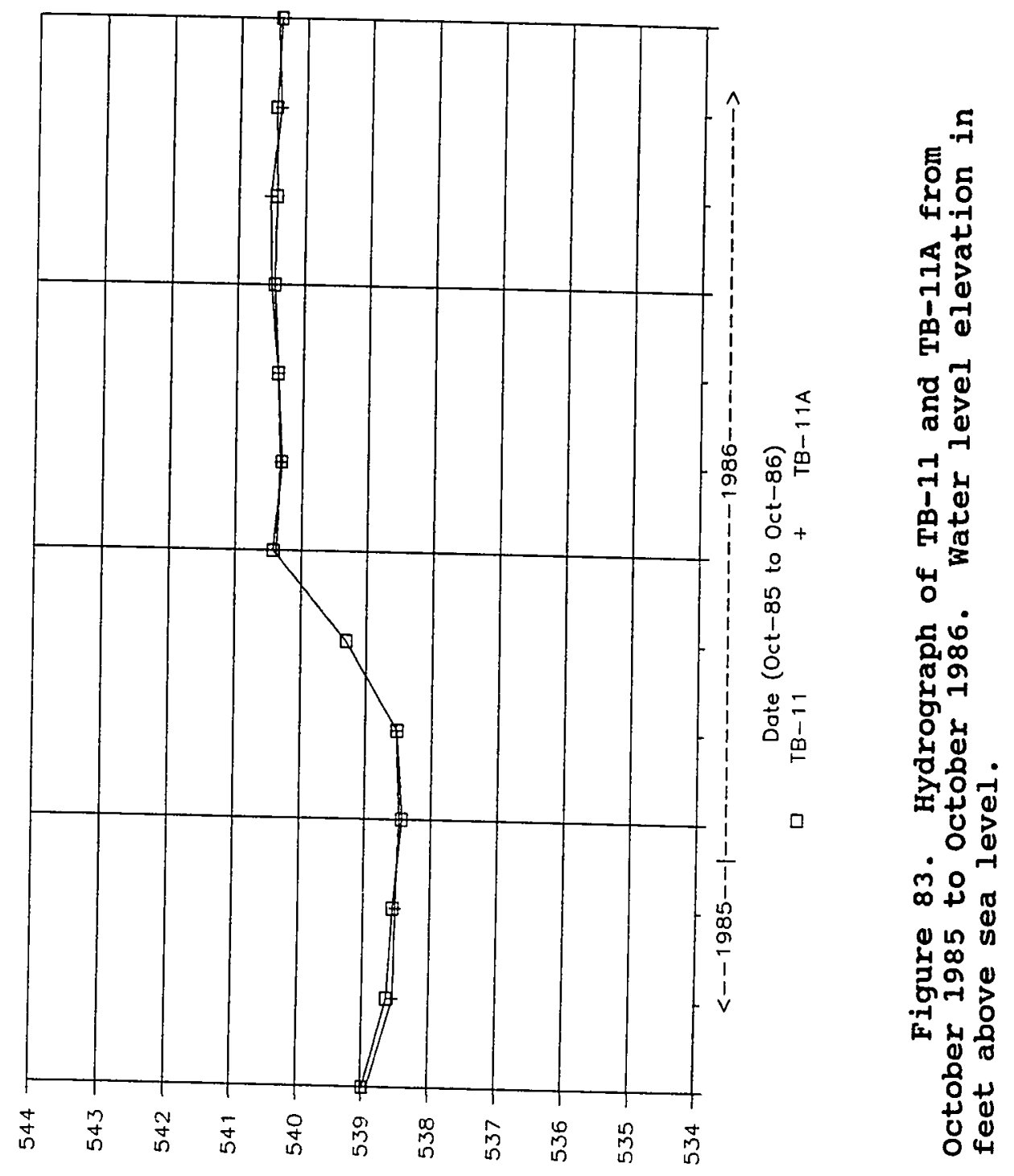













\begin{abstract}
APPENDIX D
SOIL RESISTANCE GRAPHS,

SEPTEMBER 26,1985 TO OCTOBER 1, 1986
\end{abstract}













(sแ40) aJupzs!saj l!OS 




ن 


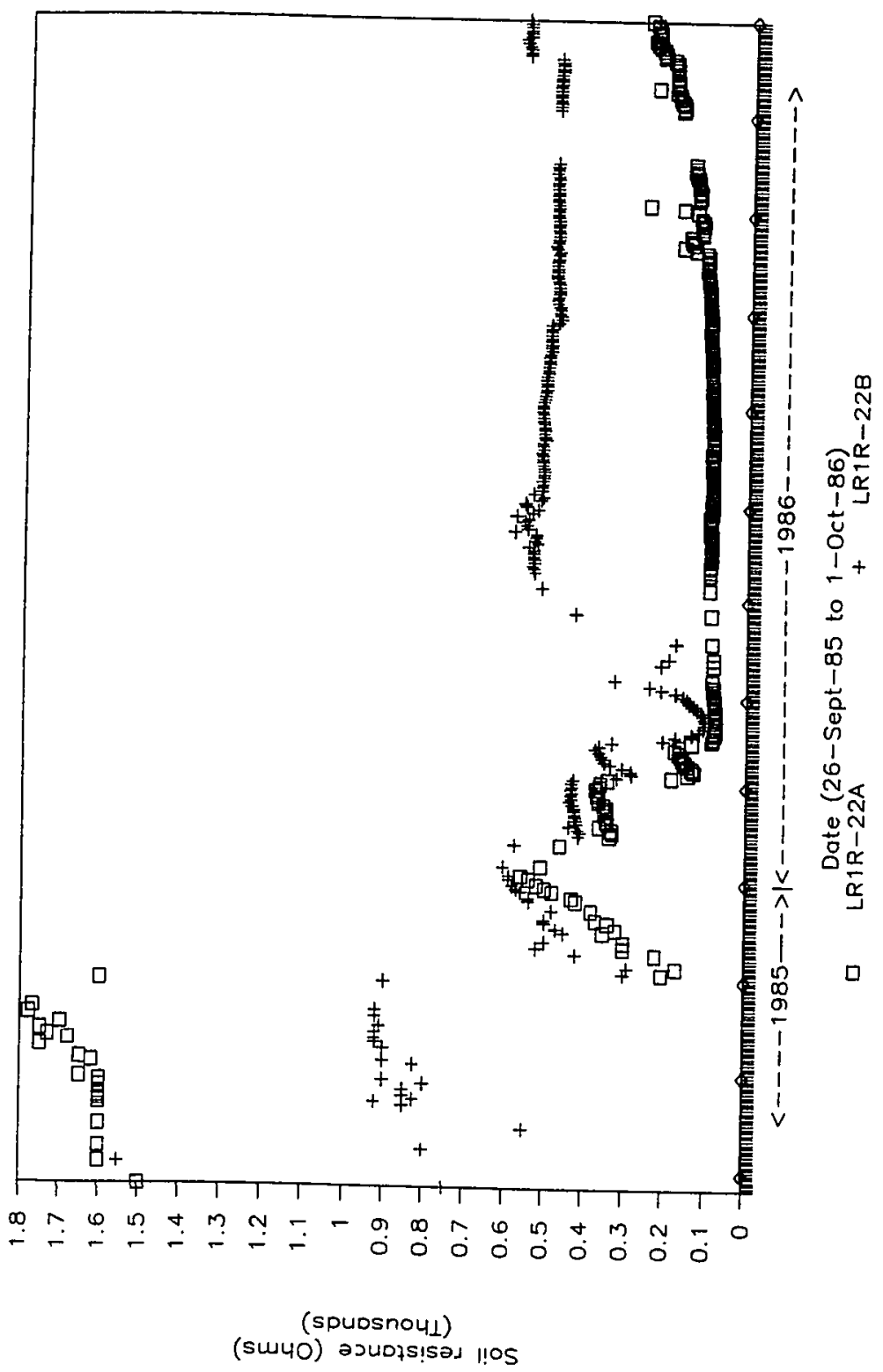



40

4 N

क्ष

茴定

ช。

ป气 葛

๒

in

-

ฮ

岀 岁

品

옹

4 웅

○ ूू



.

i)

เก 0 -

$\infty$ क

๗N

㟧



का

$\rightarrow 0$

뭄움

(su40) asudis!sas l!OS 




(sw40) әวudjs!saj 1!OS 







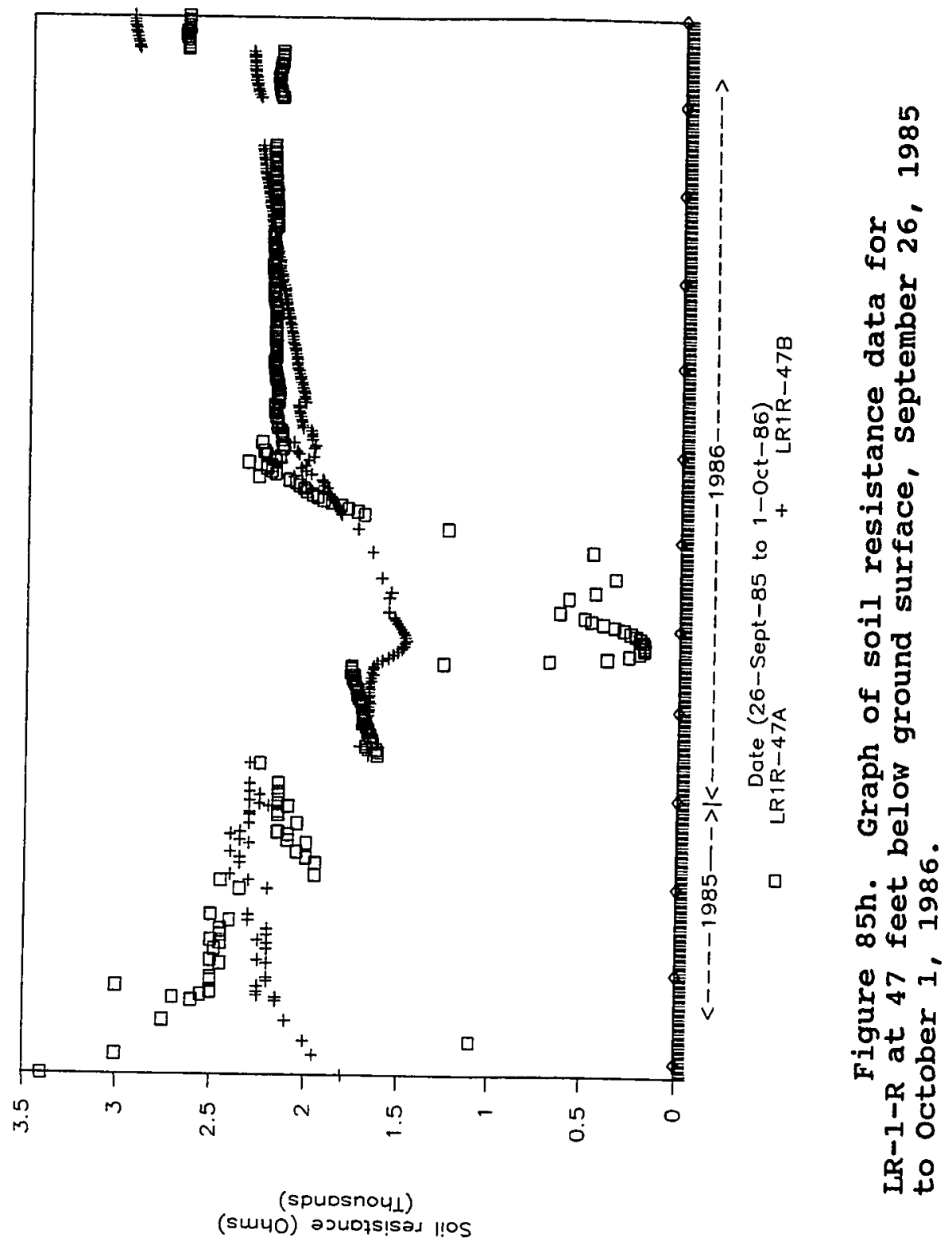











(sس40) ә2น075!s27 l!OS 






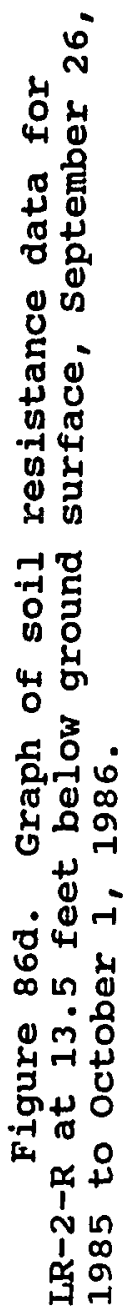






(smuO) asudzisan lios 


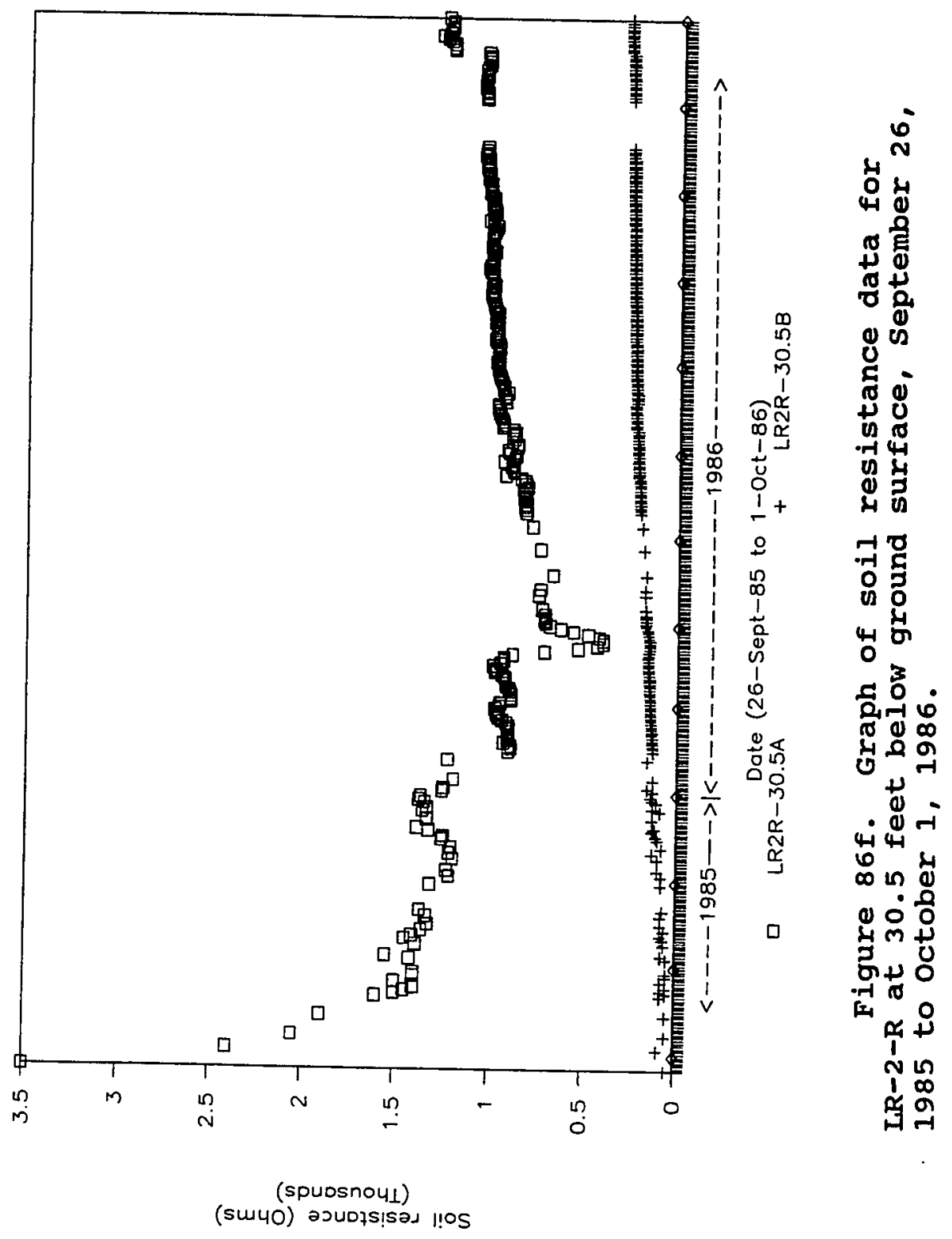



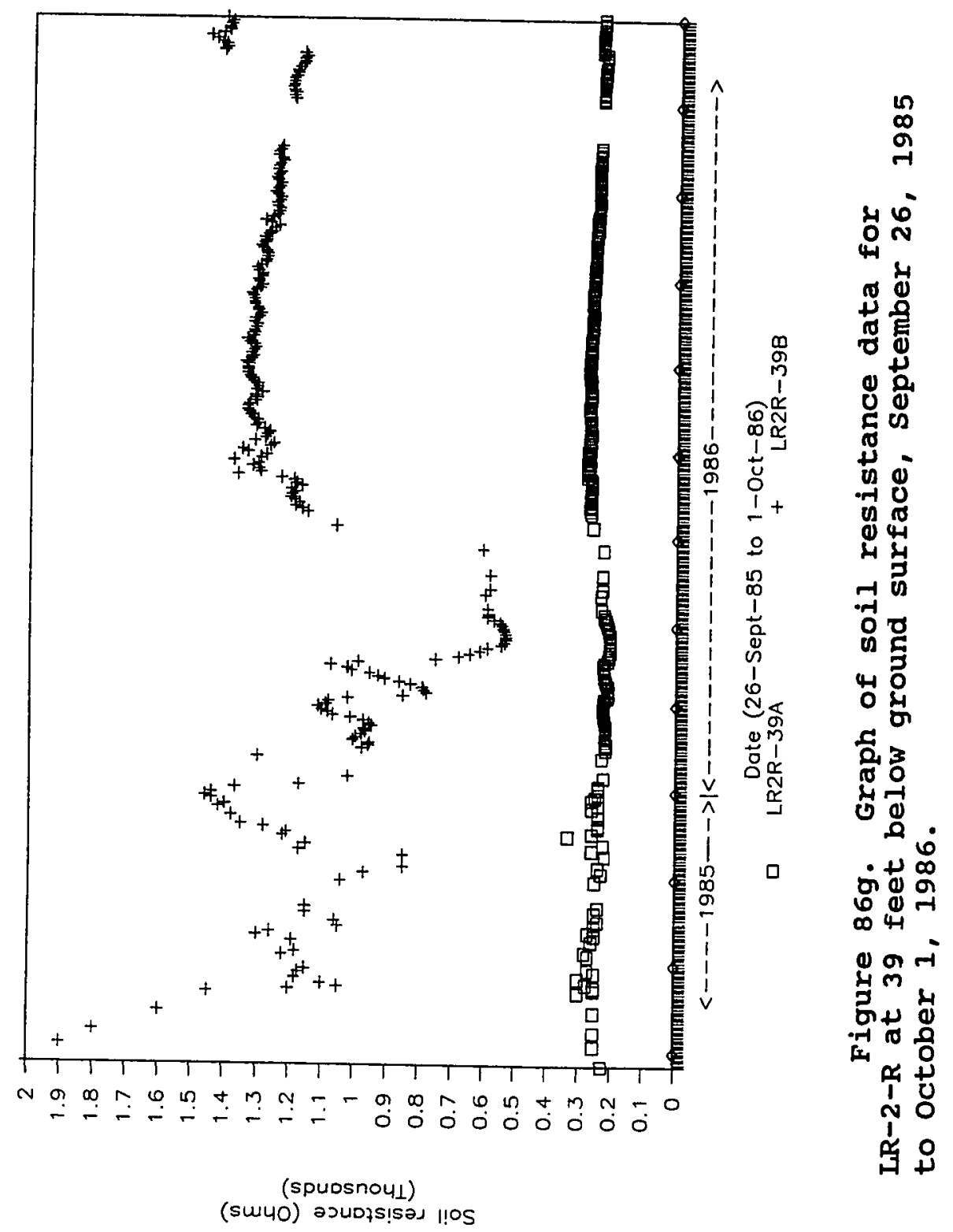






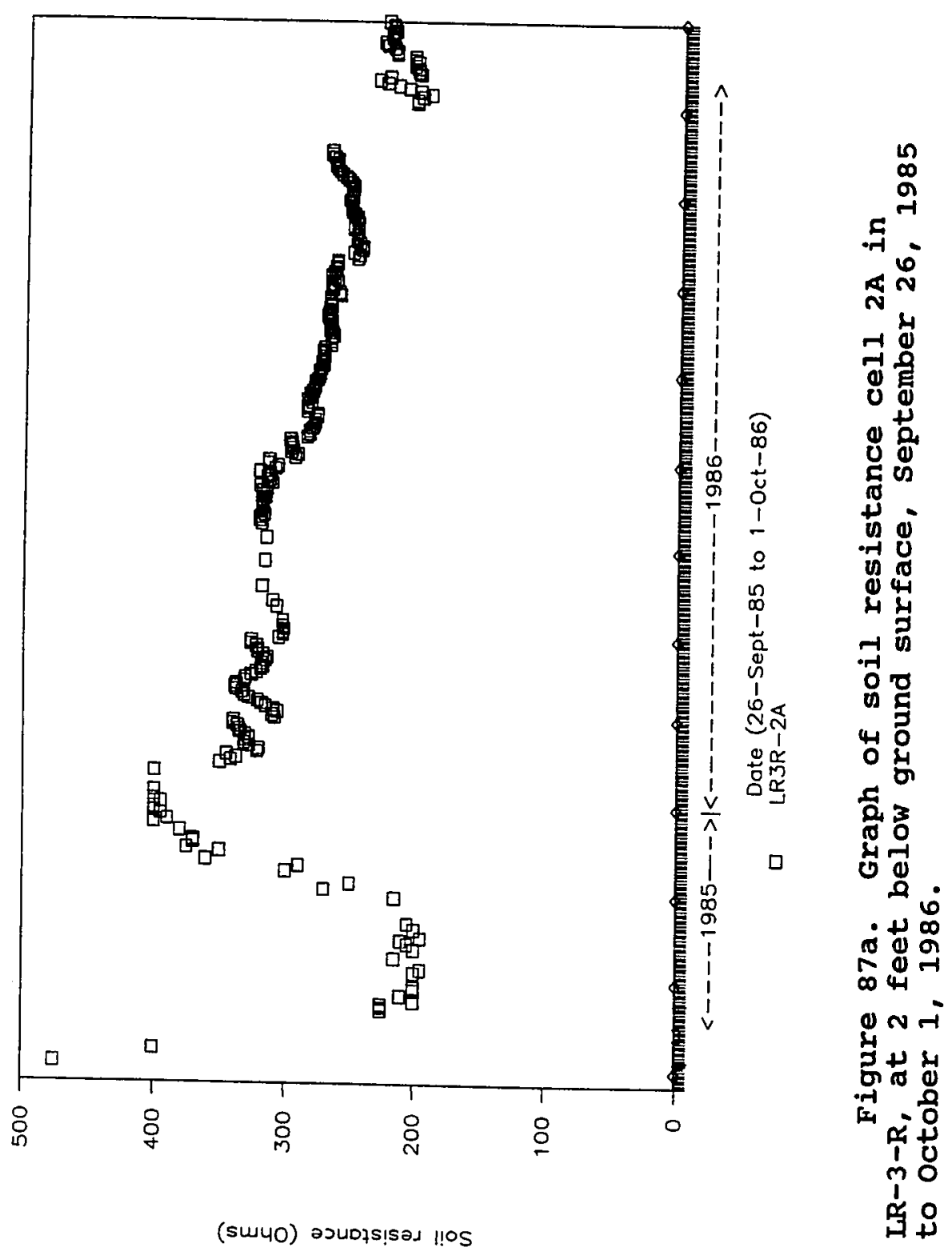




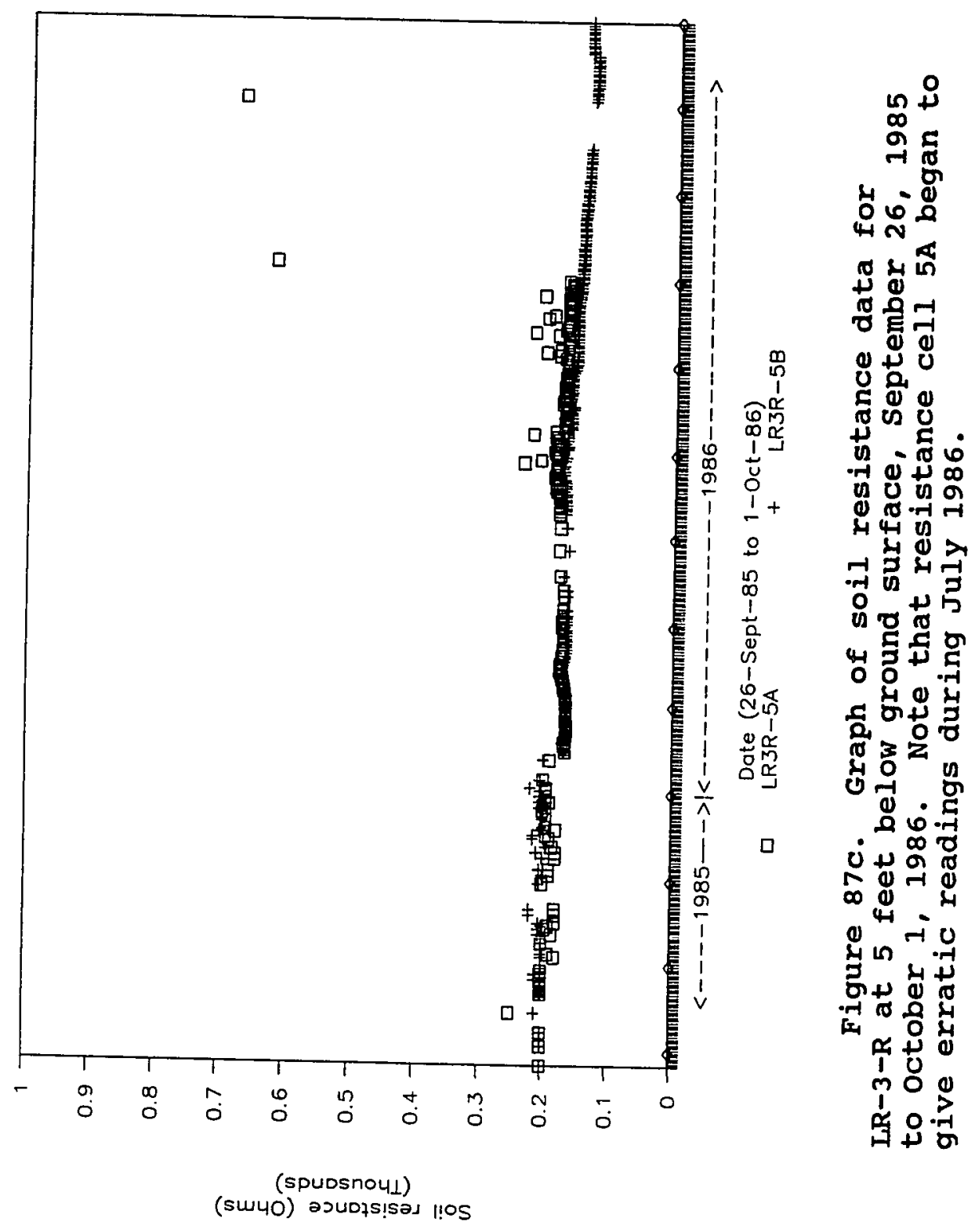



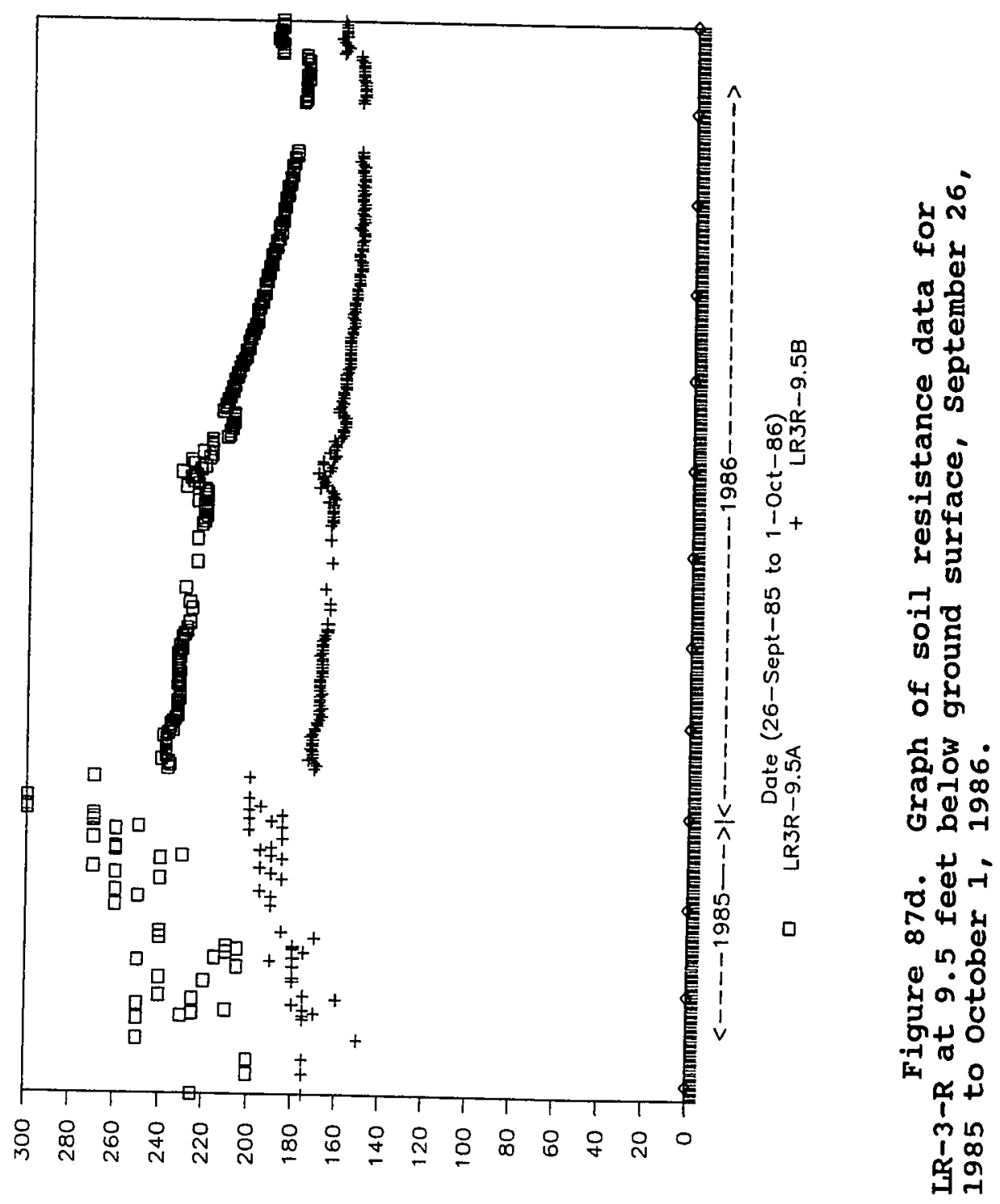

(sแ40) 200075!sad 1!OS 






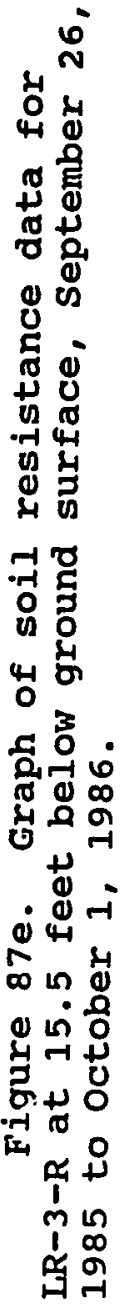



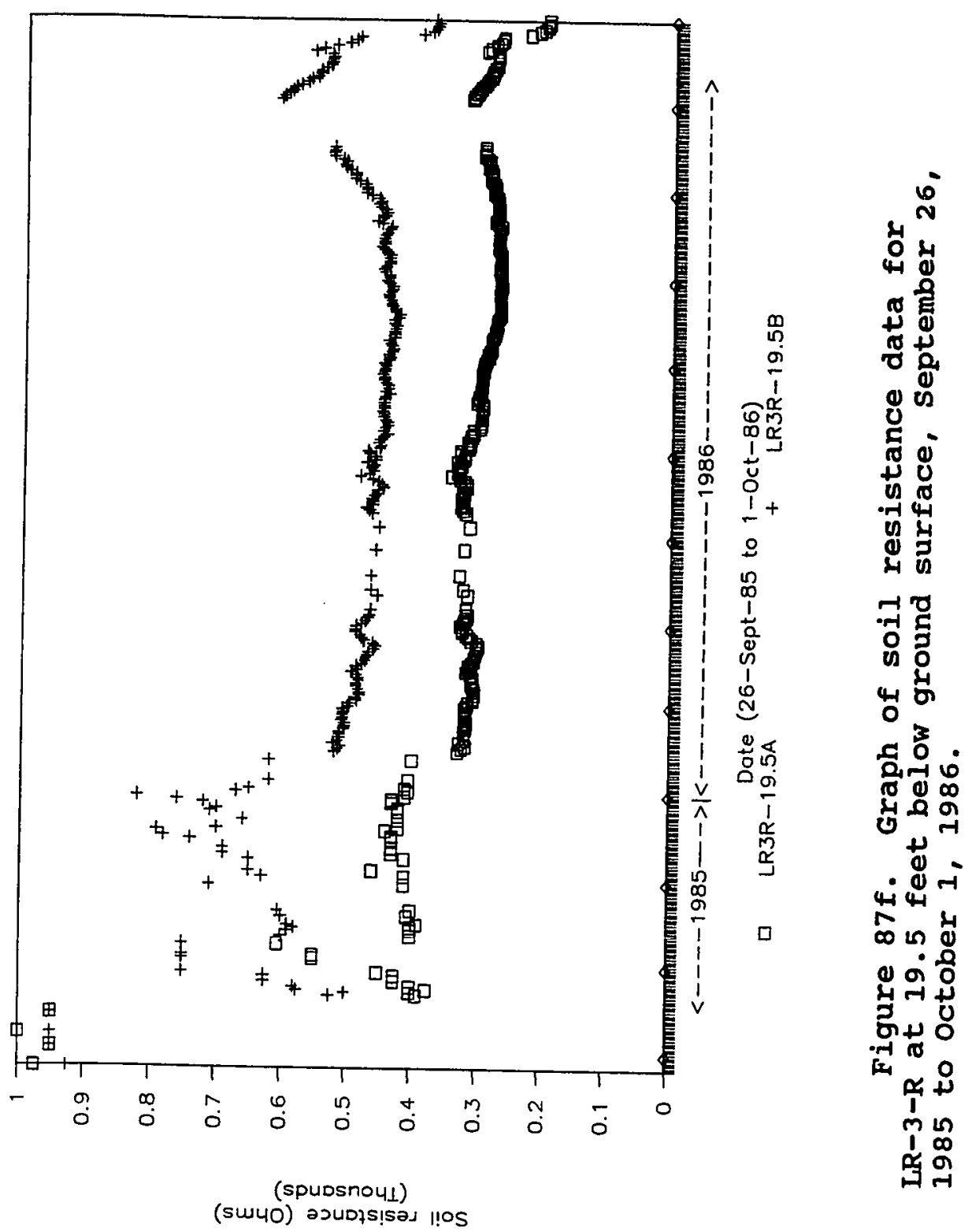

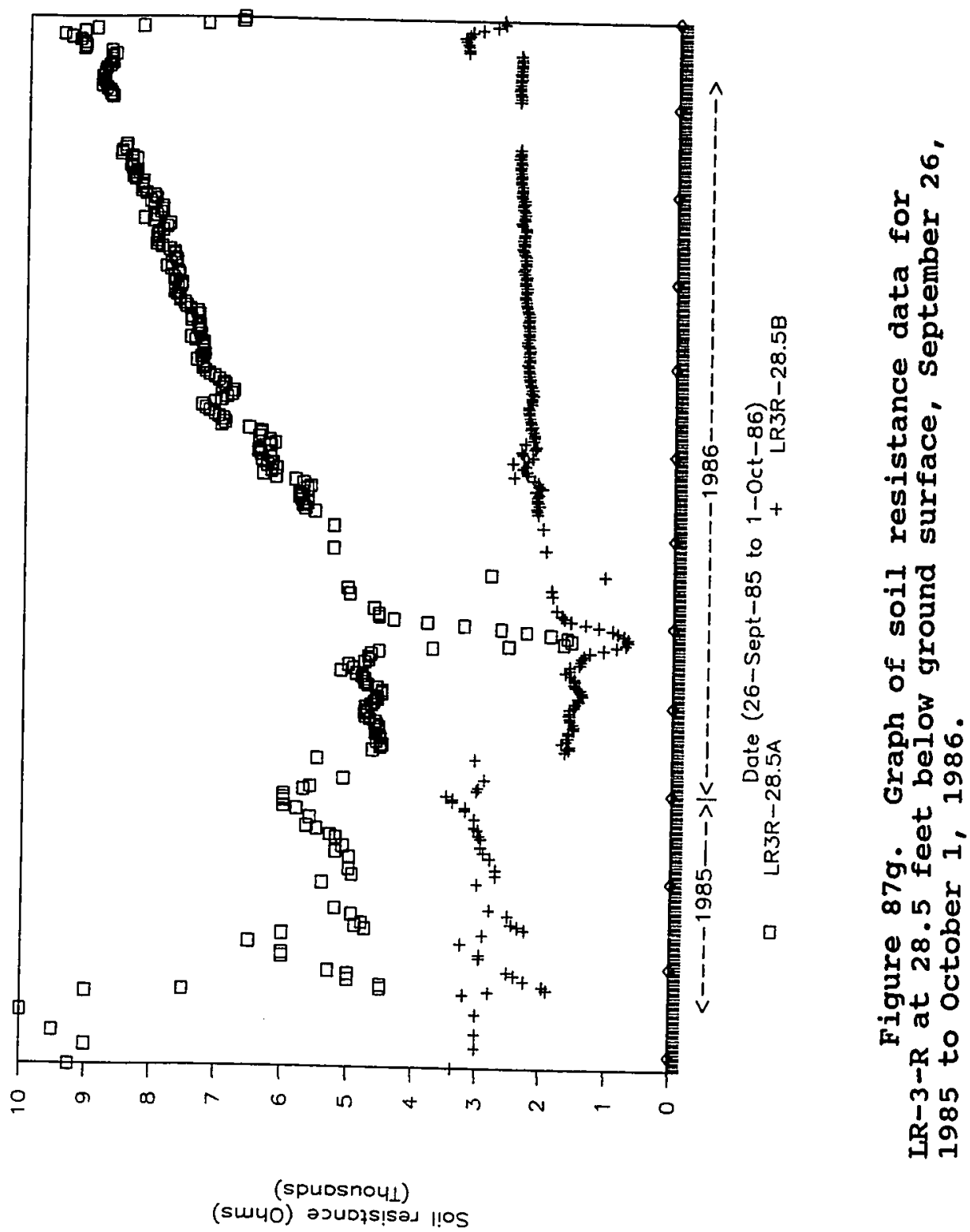

o) asudis!sad l!os 







APPENDIX E

SOIL RESISTANCE RELATED TO THE

FEBRUARY 11-19, 1986 STORM 
SOIL RESISTANCE DATA AND

THE FEBRUARY $11-19,1986$ STORM

\section{Introduction}

This appendix includes a discussion of the ground water movement in the vadose zone following the onset of the February 11-19, 1986 storm, graphs of the soil resistance between February 10 and March 3, 1986 (figs. 88a through 90i), and cross-sections which show the progression of the wetting front and the time when a maximum moisture content occurs (figs. 9la through 91e and 92). The cross-sections summarize the spatial and temporal distribution of ground water flow in the vadose zone under the drainage retention basin.

As long as there is ponded water, there will be some infiltration into the subsurface. When the pond size increases, so does the volume of water which is infiltrated from the basin. The infiltration rate is greater at high pond levels because of an increased surface area for infiltration and a larger hydraulic head difference. This causes additional water to percolate through the vadose zone. The increased ground water flux through unsaturated sediments causes the moisture content and hydraulic conductivity to increase. A decrease in the soil resistance reflects 


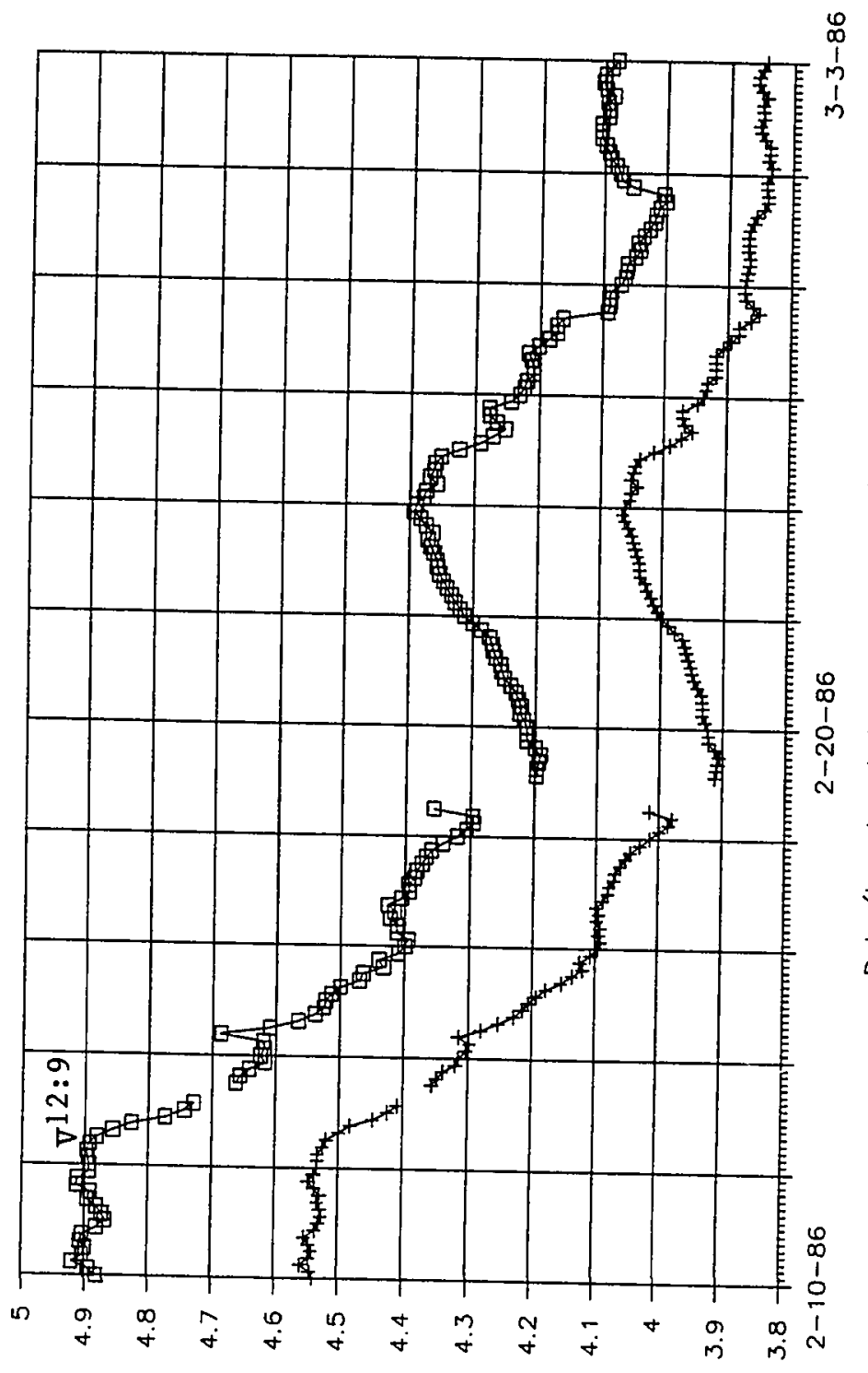

(sw40-O!! U!) әวU07s!səy








(sw40-O!!y u!) әدU1;s!say 







206



(smuo-o!! u!) asuojs!say 




(sw40-01!r u!) asudis!say 


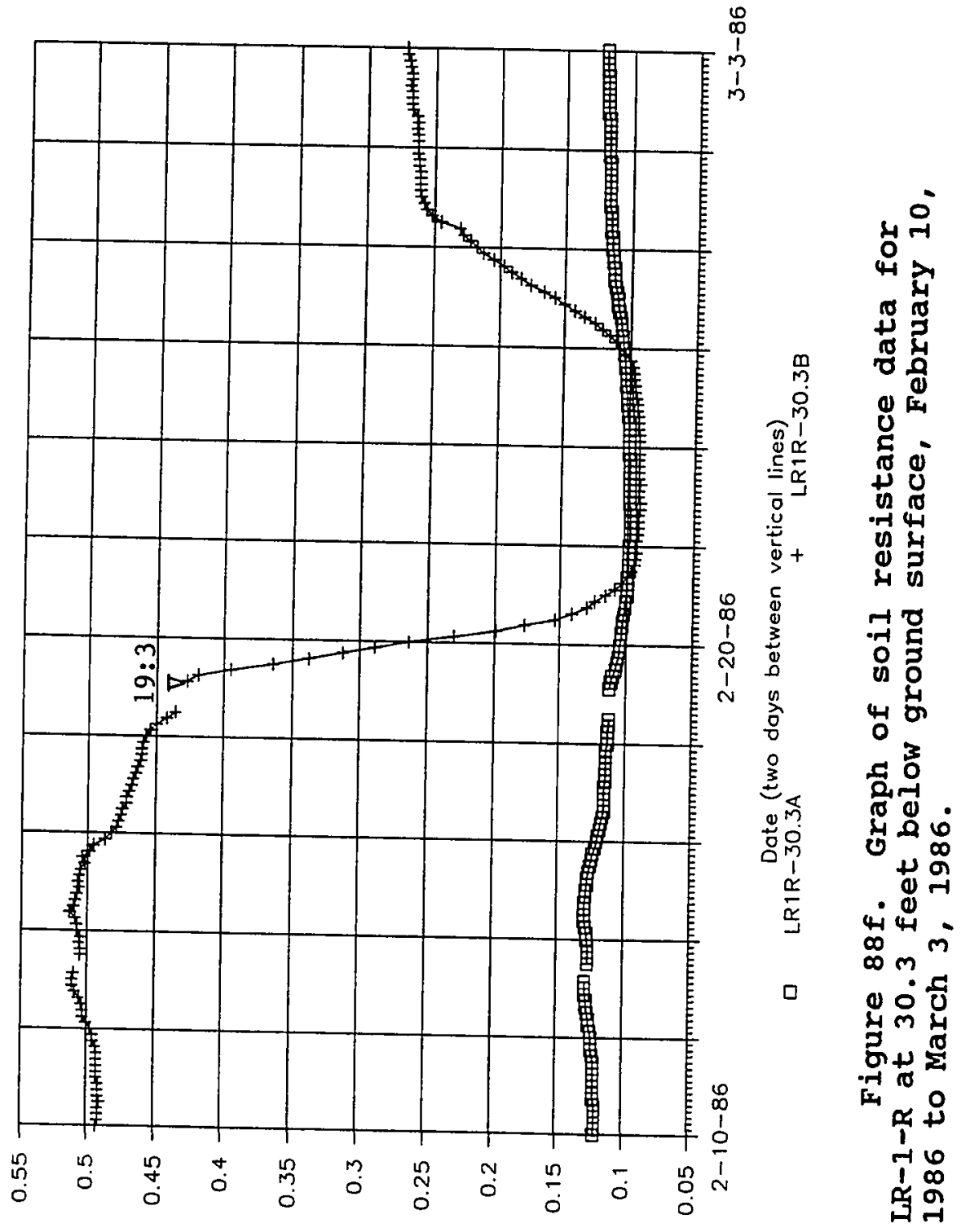

(sw40-Ol!y u!) asuojs!say 




(sw40-0!!y u!) әวuסjs!say 


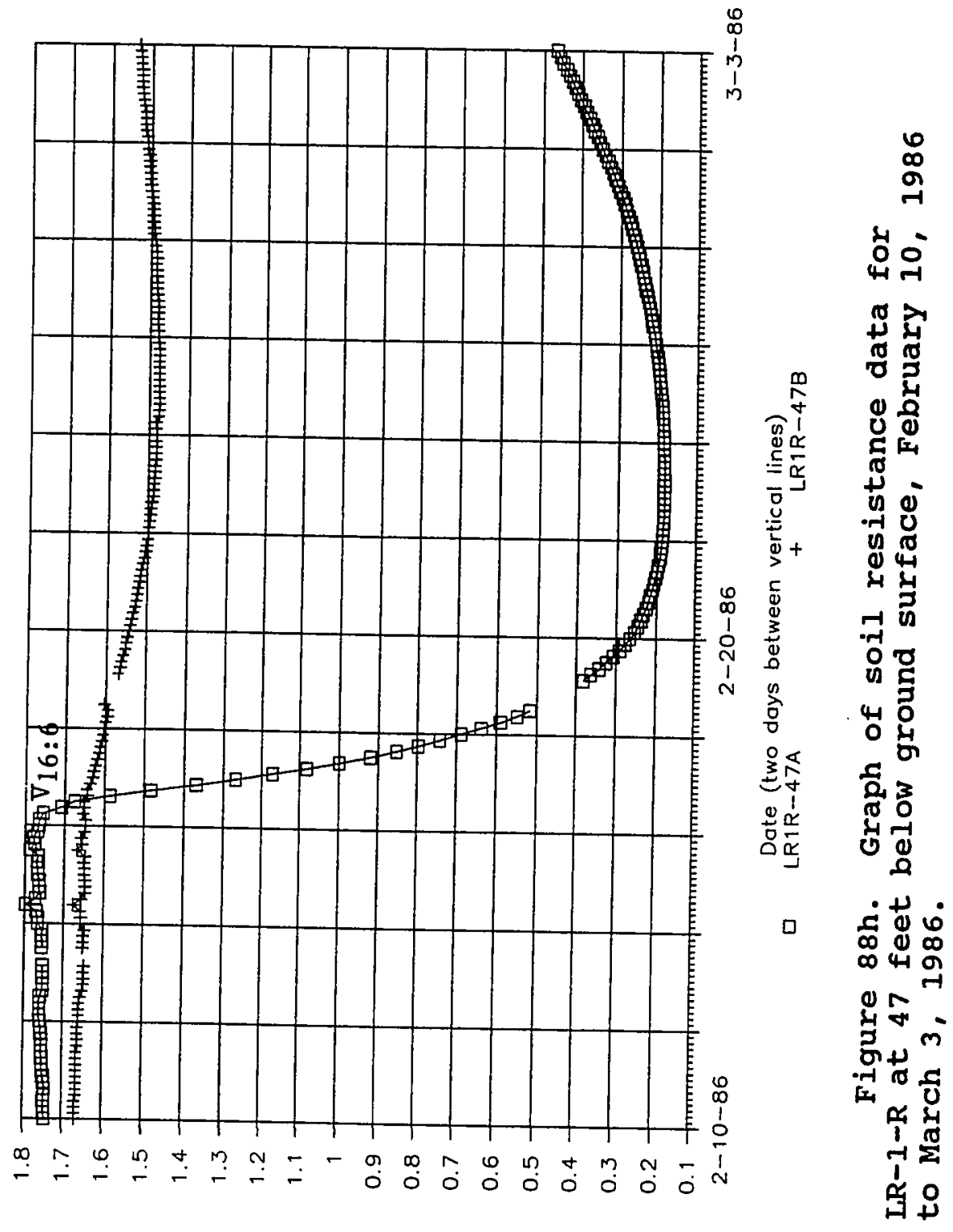

(sw40-0!! u!) ә0407s!səy 


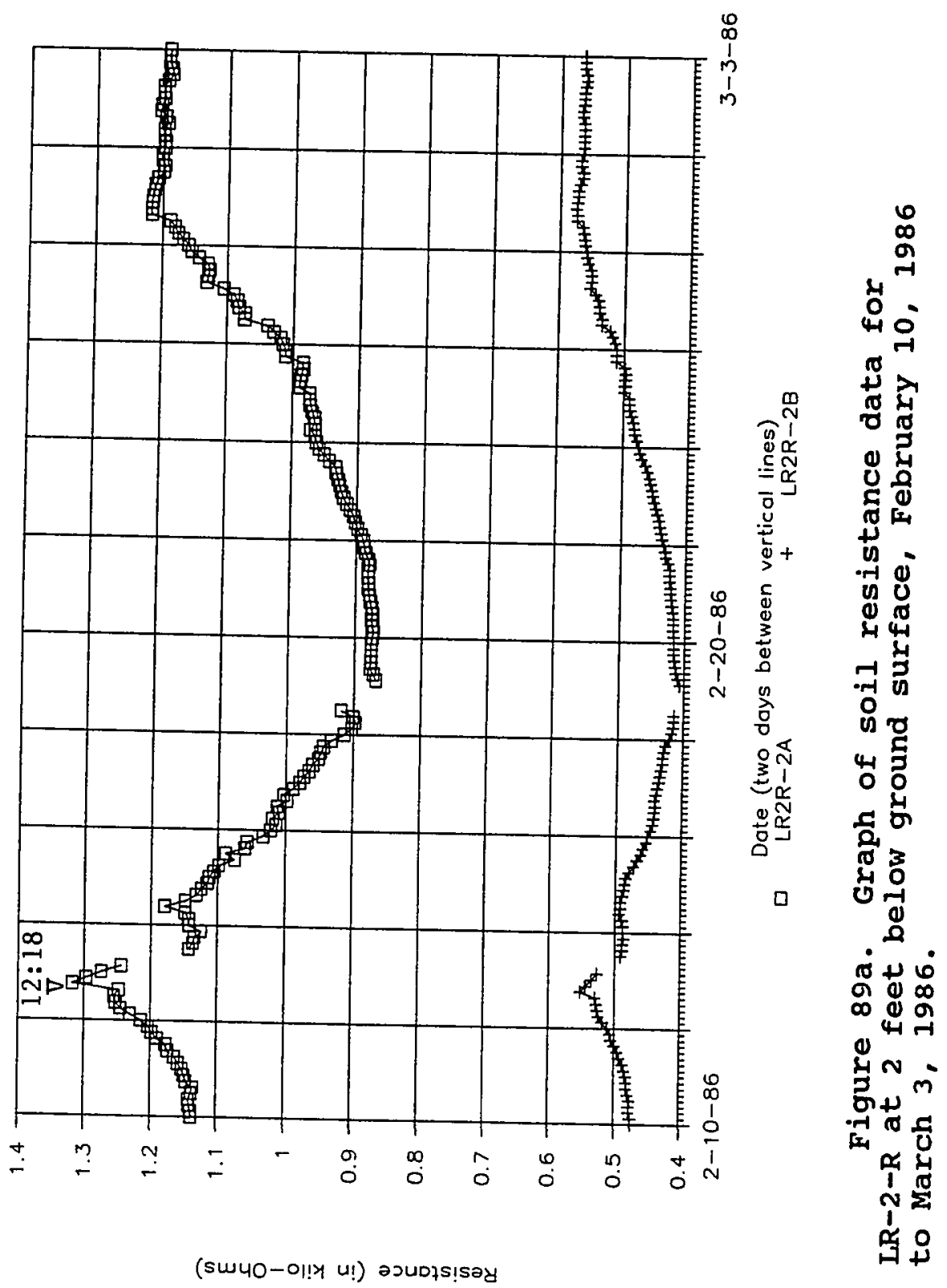






(swuo-ol!r u!) asuojs!say 




(sw40-ㅇ! u!) әวuㄱs!say 

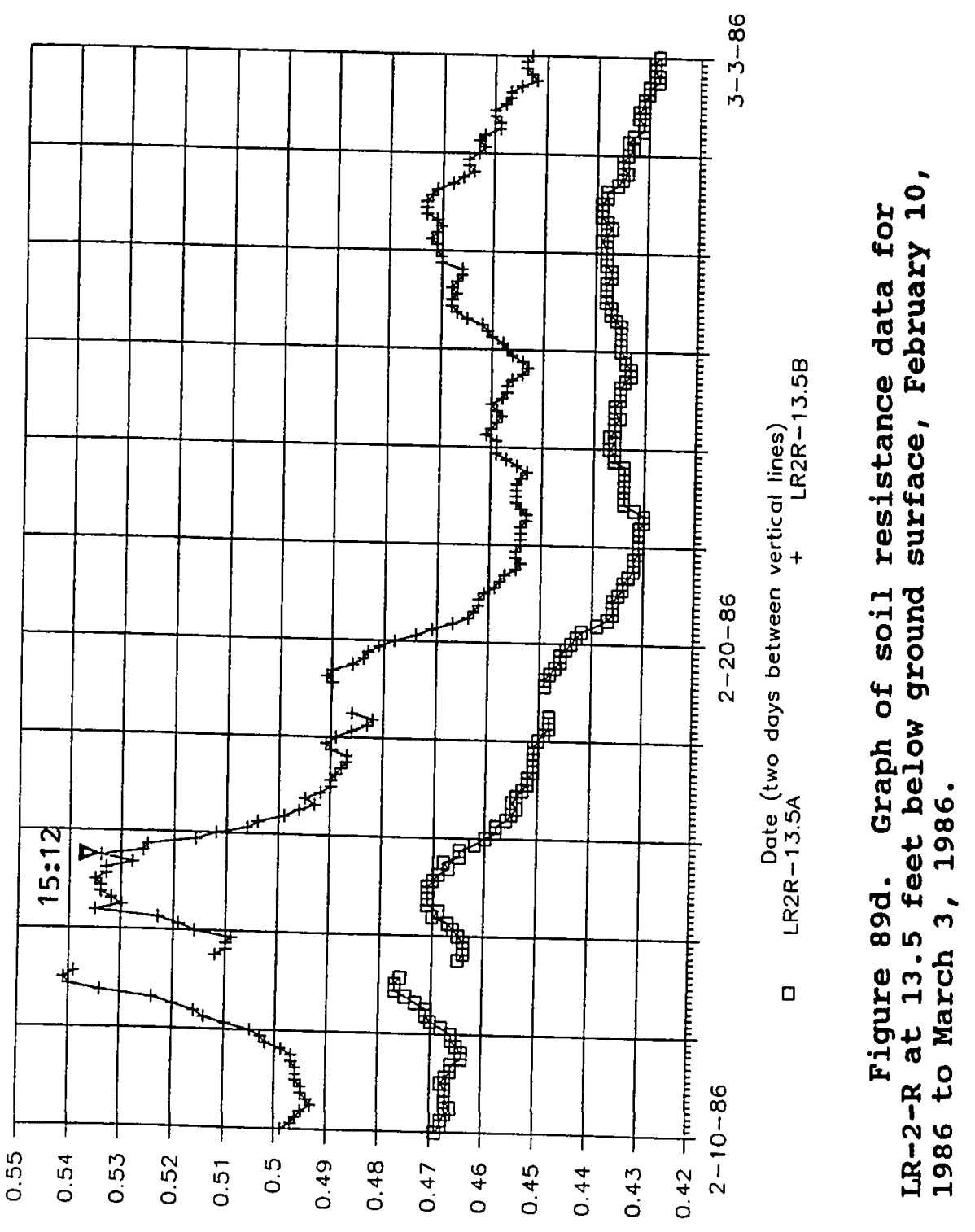

(sm40-0!!Y u!) әวuDjs!say 

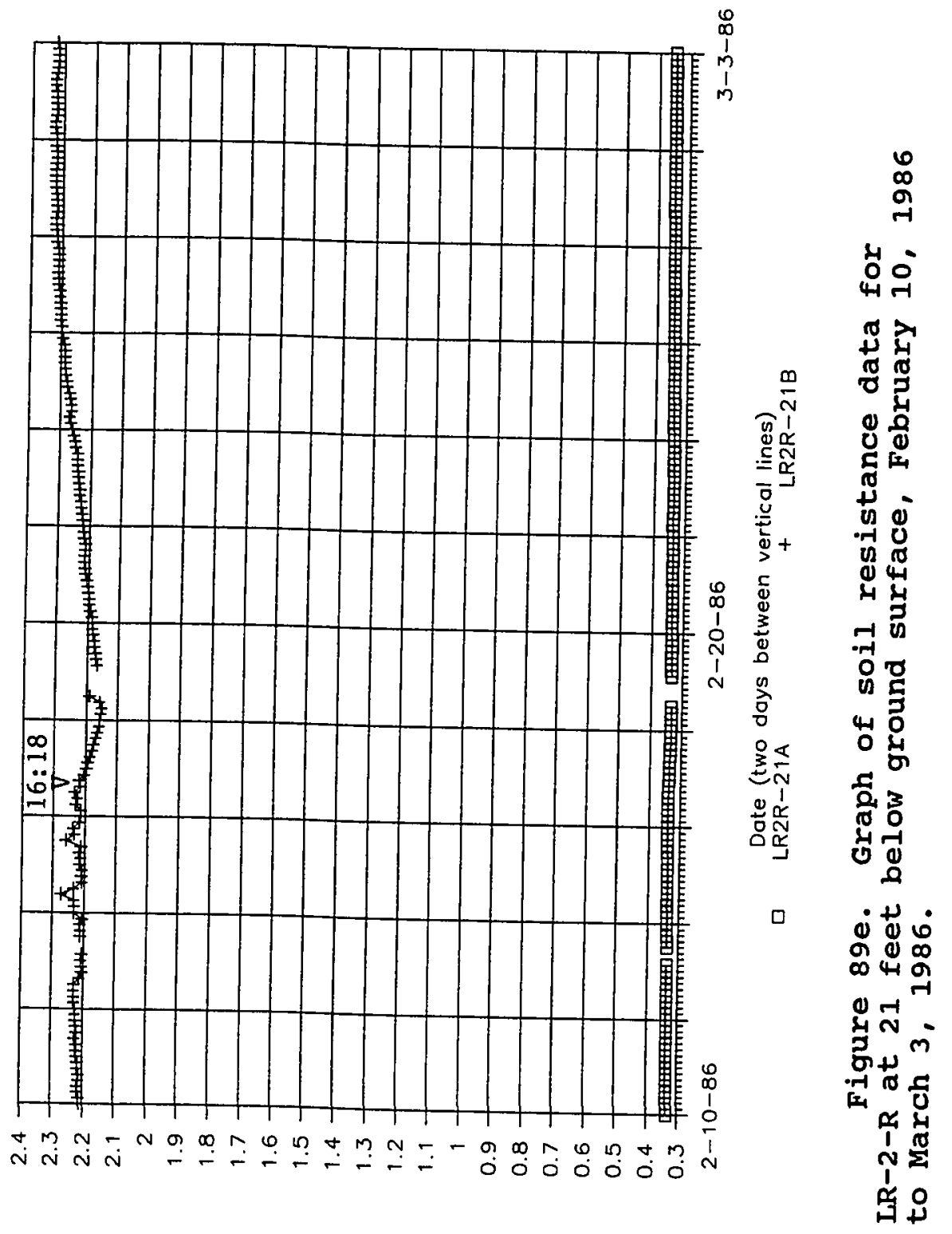

(sแ40-0|!y u!) 22007s!say 




(sw40-0!! u!) ә2u07s!say 




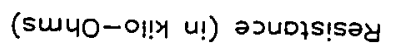






(sw40-0|!1 U!) әวuסłs!say 




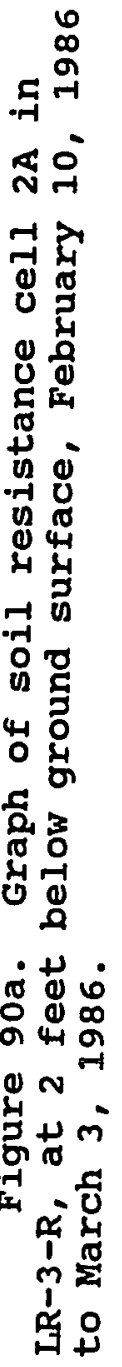

(smuo-ol!y u!) asuojs!say 


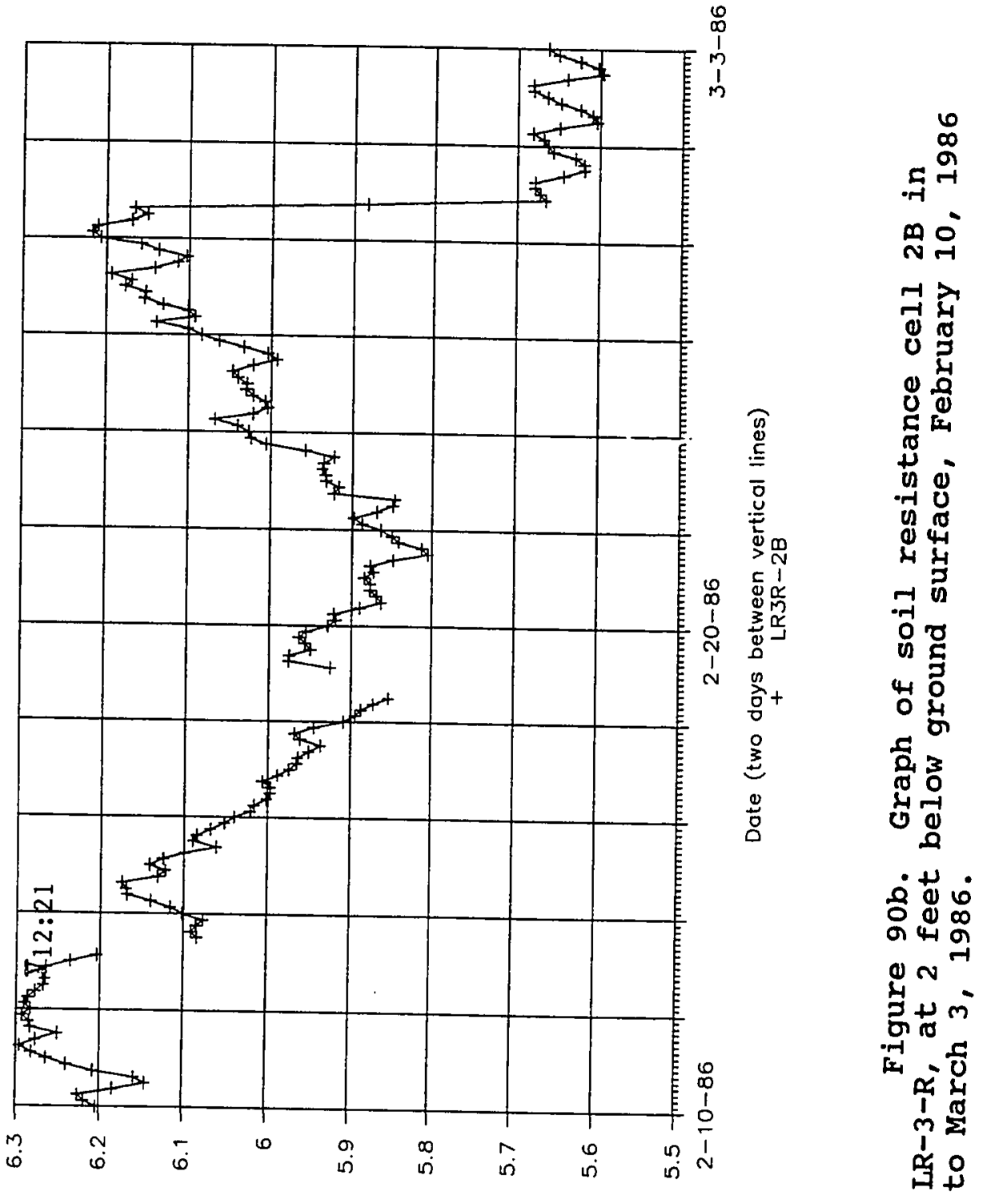

(sw40-O!!Y U!) asudzs!say 




(su40-ol!r u!) asudis!say 



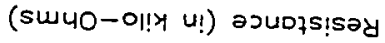












(sw40-인 4!) әวUDis!say 




(sw40-O!! U!) әدudis!səy 



(sس40-이 U!) әวบDłs!səy 






(su40-0!! u!) әxuDis!səy 







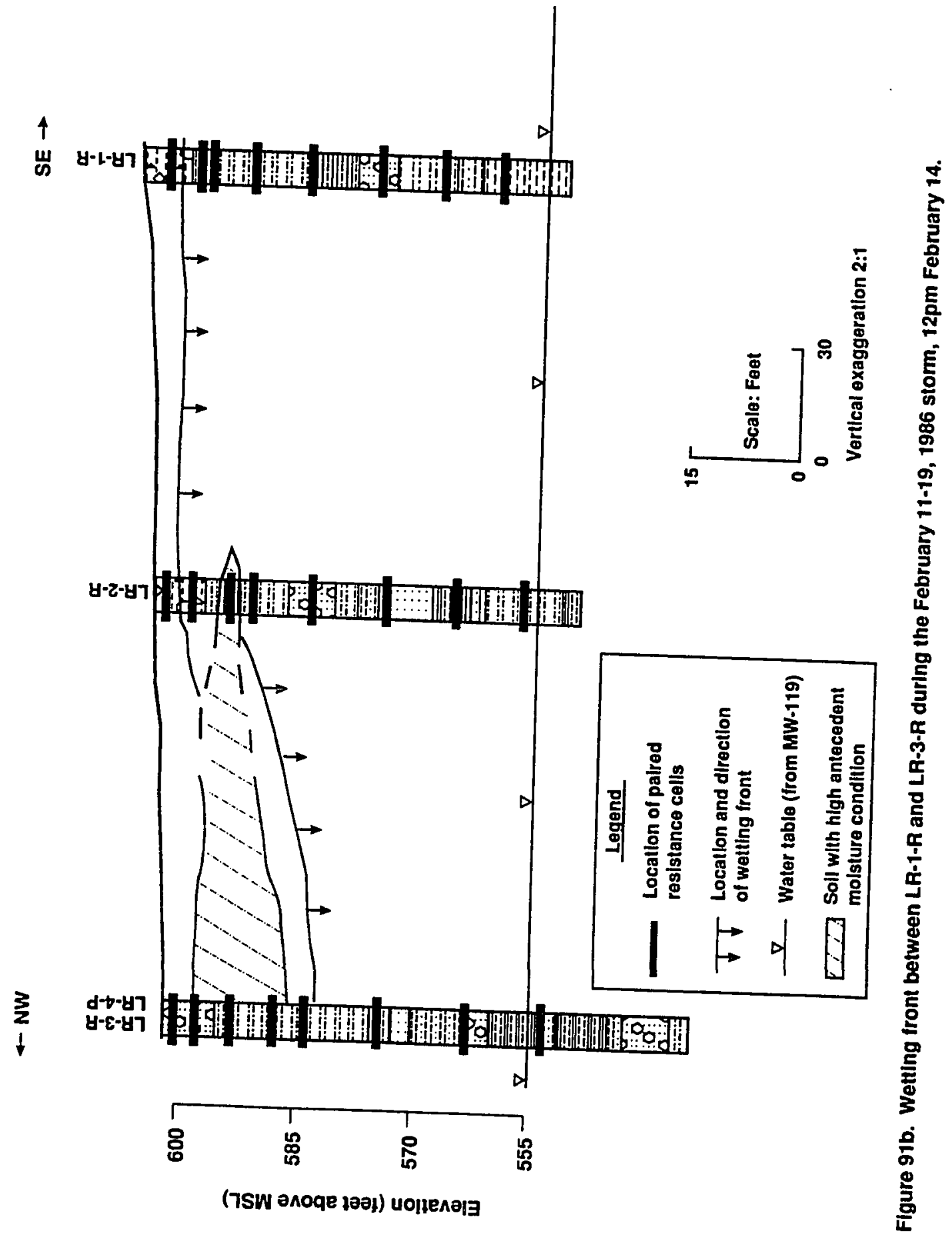




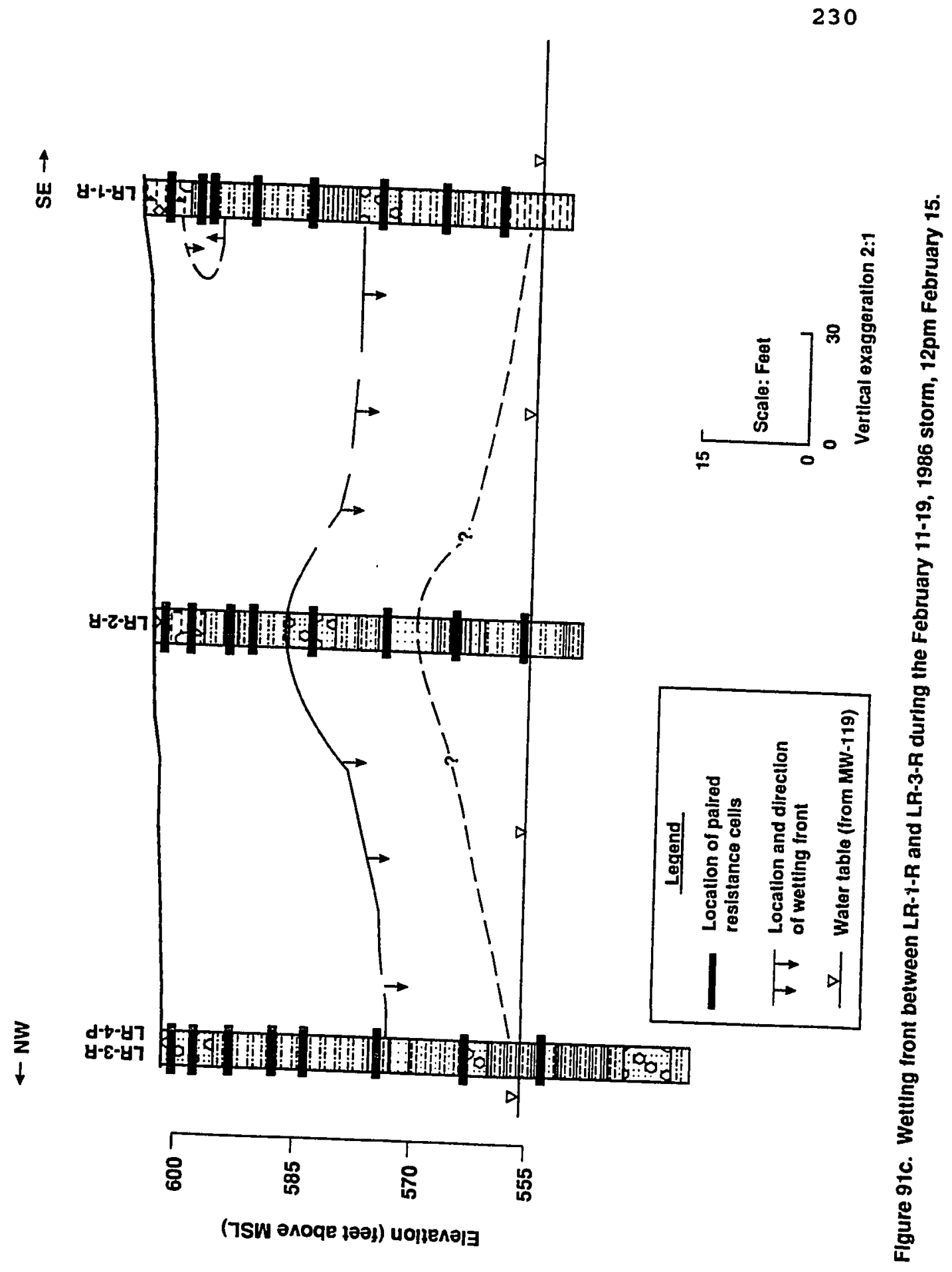




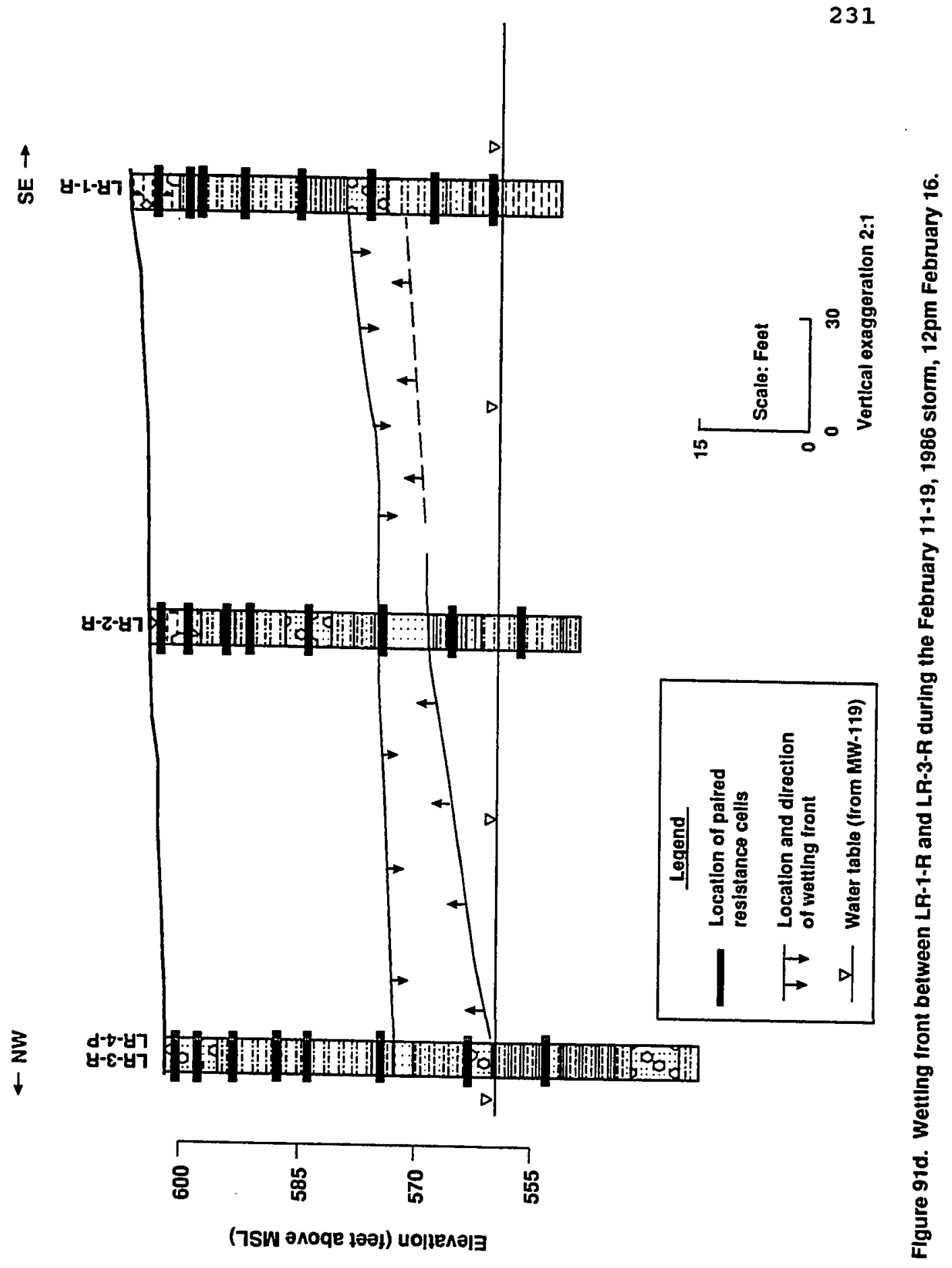












an increased moisture content and thus indicates the increased ground water flux.

Initial Wetting (February 12-16)

A slight increase in moisture is noticed in all of the uppermost resistance cells (figs. 88a, 89a, 90a, 90b, and 9la) within 30 hours after the beginning of the storm (in the evening of February 11). The increased depth of ponding in the basin would cause a greater pressure head so that additional water would percolate and affect the moisture content in the uppermost soil near $L R-3-R$. At $L R-2-R$, the resistance drop coincides with increased infiltration due to the expansion of the pond over $L R-2-R$. $L R-1-R$ contains the first resistance cell to respond, even though it was inundated after $L R-2-R$. The rapid response at $L R-1-R$ is probably due to drier antecedent conditions and a higher infiltration rate than at $L R-2-R$. The soil resistance in the uppermost stations at $L R-2-R$ and $L R-1-R$ continues to drop steadily until February 19 when the pond is at its capacity. The uppermost station at $L R-3-R$ shows a much gentler decline in soil resistance. This is probably due to high antecedent moisture conditions and a low 
infiltration rate due to a silt layer at the ground surface.

The next station that shows an increased moisture content is at a depth of 22 feet $(6.7 \mathrm{~m})$ in $L R-1-R$ (noon, February 13, fig. 88e). Even though the moisture flux at that time is not as large as the flux seen two days later, the resistance drop at this location prior to a response in the overlying resistance cells at a depth of $6,8,13.5$ feet $(1.8$, 2.4 , and $4.1 \mathrm{~m}$ ) (figs. $33,88 \mathrm{~b}, 88 \mathrm{c}$, and $88 \mathrm{~d}$ ) suggests the existence of a ground water flow path around the overlying silt layer. The clayey silt, 6.5 feet $(2 \mathrm{~m}$ ) below the basin, should impede ground water infiltration immediately above and through this material (fig. 16). A hydraulic connection may exist through the 35 feet $(10.5 \mathrm{~m})$ of moderately permeable sediments (clayey sands, clayey gravels, and silty sand) near D-3. A possible mechanism for the lateral migration of water under the first silt layer is the perching of water on contacts between sediments of contrasting permeabilities. Some water may have perched and spread laterally, as soon as 42 hours after the onset of the storm, on the contact found at a depth of 22 feet $(6.7 \mathrm{~m})$ in $L R-1-R$ between a sandy silt and a silty clay. 
A slight drop in soil resistance below the first silt layer is noted at LR-3-R at the depths of 19.5 and 28.5 feet $(5.9$ and $8.7 \mathrm{~m})$ by midnight February 14 (figs. 90e, 90f, and 91b). This suggests some hydraulic connection through or around the first silt layer similar to that near $D-3$ and $L R-1-R$. The 50 feet $(15 \mathrm{~m})$ of highly and moderately permeable sediments (silty sands, sandy gravel, sand, and clayey sand) near D-5 (figs. 16 and 17) most likely allows ground water to rapidly infiltrate into the subsurface. Water could then flow laterally along the contacts between sediments of contrasting permeabilities towards $L R-3-R$ and $L R-2-R$.

Most of the resistance cells have started to respond by midnight February 15 (fig. 91c). The response at the deepest stations in $L R-2-R$ and $L R-3-R$ may reflect a rising water table and its associated capillary fringe (figs. 89g, 89h, and 90i). The deepest station at $L R-3-R$ was 5 feet $(1.5 \mathrm{~m})$ beneath the water table since the February 1, but increased hydraulic heads due to the rising water table could accelerate the flux of water into the silty material surrounding that location.

The resistance cells at a depth of $5.5,9.5$, and 14.5 feet $(1.7,2.9$, and $4.4 \mathrm{~m}$ ) in $L R-3-R$ show a 
minimal response to the February 11-19 storm (figs. 90c, 90d, and 90e). This lack of a response may be attributed to a very low permeability and a high antecedent moisture content at these locations. The resistance cells at a depth of 39.5 and 47 feet (12 and $14 \mathrm{~m}$ ) in $L R-1-R$ did not show a response until 9 and 6 am February 16, respectively, at which point they started to show a dramatic drop in resistance (figs. $88 \mathrm{~g}$ and $88 \mathrm{~h}$ ).

The resistance cells in the clean sand at a depth of 21 feet $(6.4 \mathrm{~m})$ in $L R-2-R$ is one of the last locations to show an increased moisture content (noon, February 16, fig. 89e). This station shows a very small drop in soil resistance. The delayed and small response in the clean sand to the February 11-19 storm is most. likely due to a very low unsaturated hydraulic conductivity. Apparently, the surrounding clayey silt and silt prevents large quantities of water from infiltrating into this area. The water that does infiltrate into the sand lens needs some time to accumulate, in order to overcome the capillary tension in the fine grained deposit, before the water can enter the sand. Not enough water infiltrates to this area to cause a large resistance drop such as that which was seen in other highly permeable deposits. It 
is not surprising that this area is the first to return to its pre-storm condition if one considers the limited amount of water that flowed into this area and the good drainage characteristics of clean sand. $\frac{\text { Ground Water Redistribution in the Vadose zone }}{\text { (February 16-24) }}$

Resistance values continued to decrease until 6 am February 18 when the resistance in the clean sand lens at $L R-2-R$ started to increase (fig. 89e). Some of the uppermost resistance cells had a minimum value (maximum moisture content) on February 19 (figs. 88a and 89a). These resistance cells started to dry out before the deeper resistance cells (fig. 92). All of the resistance cells above a depth of 30 feet, except those which had high antecedent moisture contents, began to dry by February 24 (fig. 92).

A general decrease in the moisture content after February 20 is consistent with a decreasing volume of water which is percolating from the basin. There is a tendency for the more permeable deposits to show a greater and more rapid resistance change or moisture flux than deposits with a low permeability.

The progression of the change in moisture content appears to be affected by the sand layer at a depth of 
30 to 35 feet $(9.1$ to $10.6 \mathrm{~m})$ below the basin floor. At $L R-1-R$ the greater part of the drop in soil resistance at a depth of 30.3 feet $(9.2 \mathrm{~m})$ does not occur until the evening of February 19, more than two days after the soil above or below (fig. 88e). This may be due to the drainage of water from this layer down the surface of the lower contact of the sand layer towards the northwest and/or a result of differing characteristic curves (as was noticed in the clean sand at LR-2-R). Two days later (February 21), the resistance cells near a depth of 30 feet $(9 \mathrm{~m})$ in $L R-2-R$ and $L R-3-R$ show an increased drop in soil resistance (figs. $89 \mathrm{e}$ and $90 \mathrm{f}$ ). This highly permeable layer may have been saturated at that time because the piezometric head in MW-119 was within 4 feet $(1.2 \mathrm{~m})$ of these resistance cells when the dramatic reductions in the soil resistance occurred. 
APPENDIX $F$

DOUBLE-RING INFILTRATION DATA 










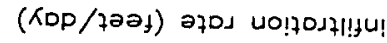







出然要 동 눙




出 I 0 证

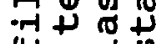
出 $斤$ 的 . ه車卉


$4 \operatorname{lin}^{4}$ 0 出 0 引




ช. मin $\dot{1}+\dot{0}$ $\infty_{0} 00$ बून मु


प्र जे

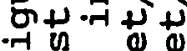
कि क्ष \& \& $-17044$

0 प्रत क पै

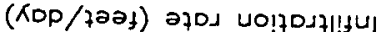




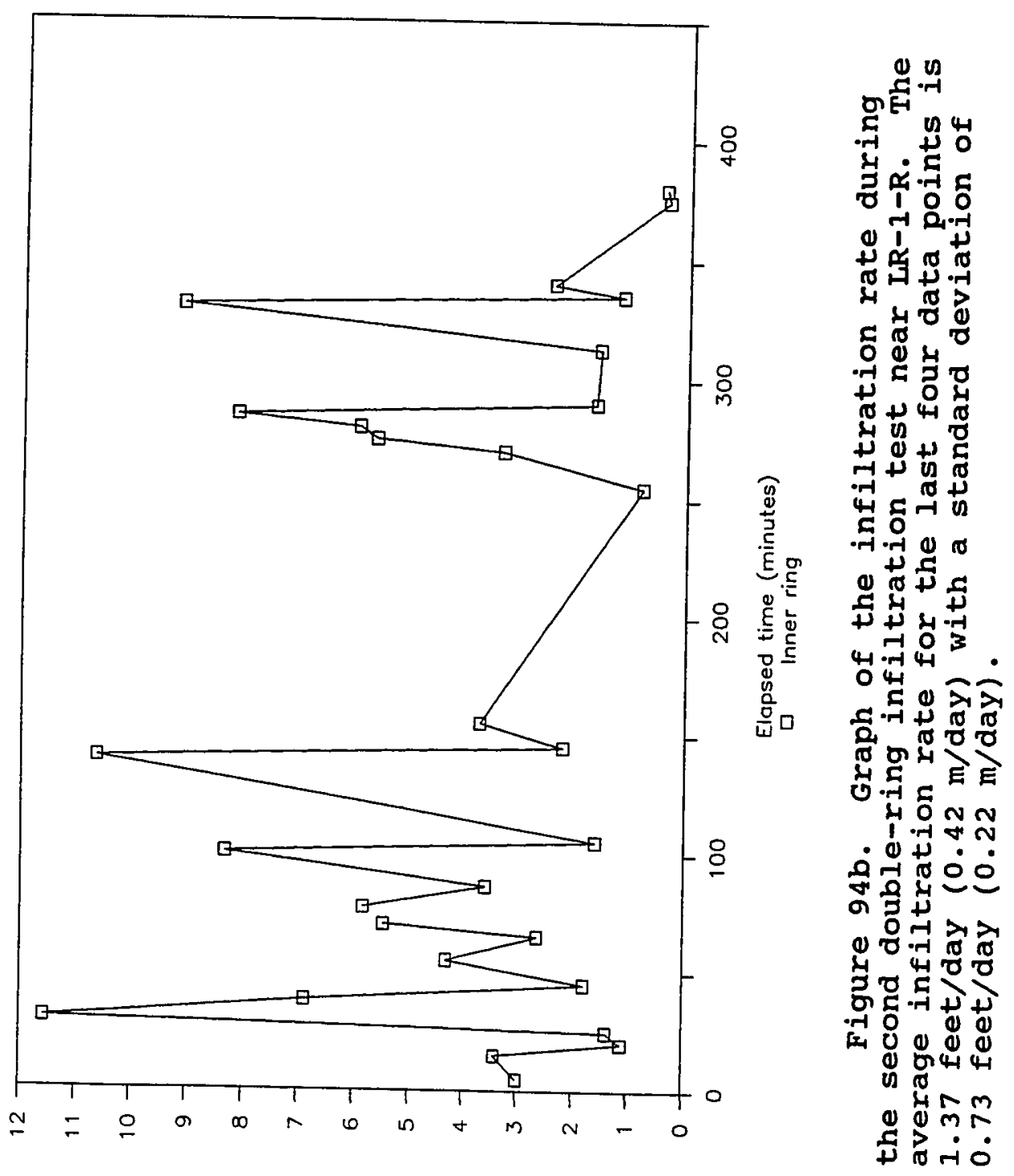





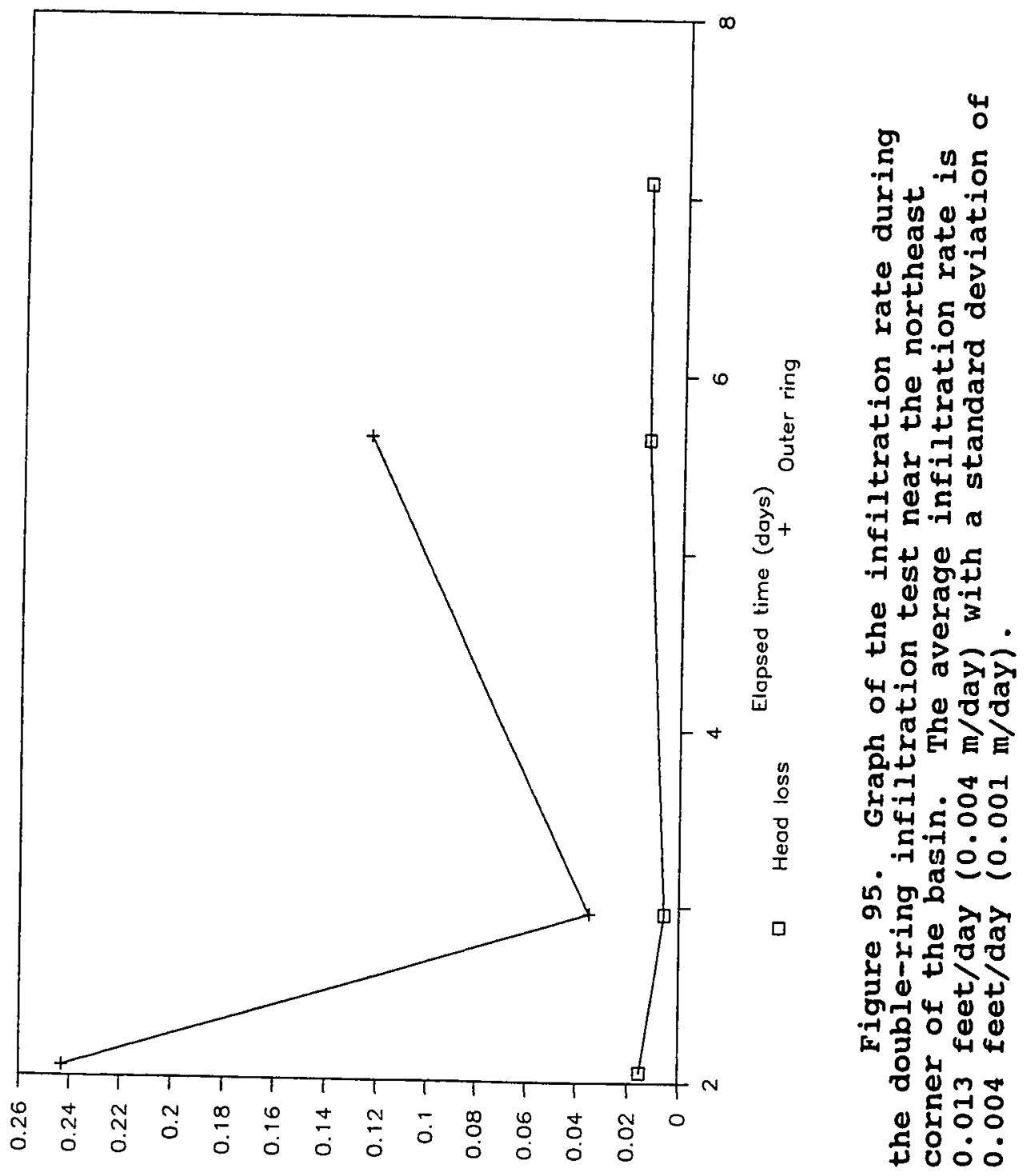






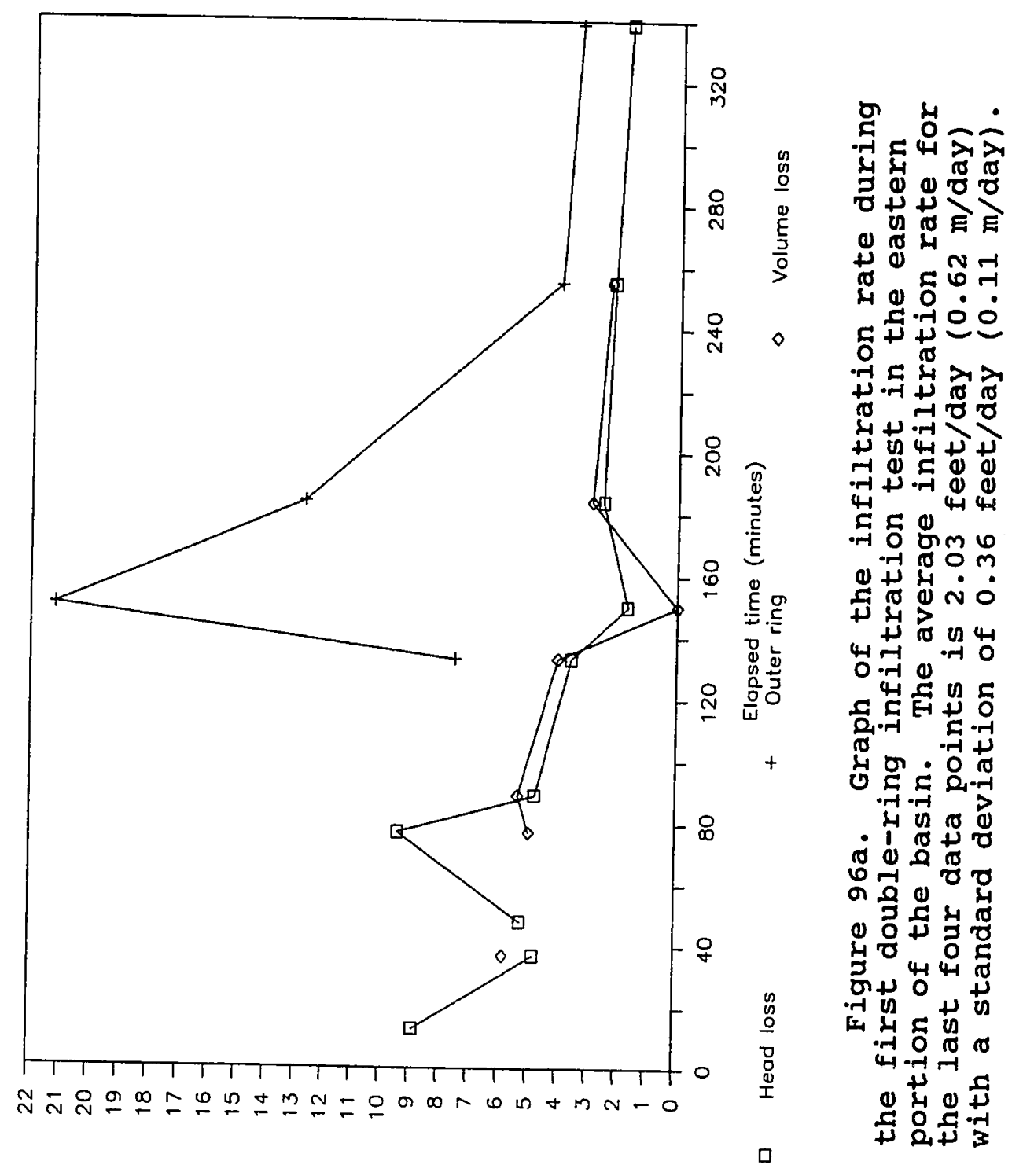

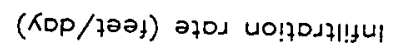


























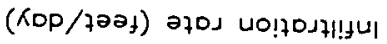


APPENDIX G

TRIAXIAL PERMEAMETER DATA 









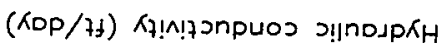



